\title{
\#USGS
}

Prepared in cooperation with the

Connecticut Department of Energy and Environmental Protection

Nutrient, Organic Carbon, and Chloride Concentrations and Loads in Selected Long Island Sound Tributaries: Four Decades of Change Following the Passage of the Federal Clean Water Act

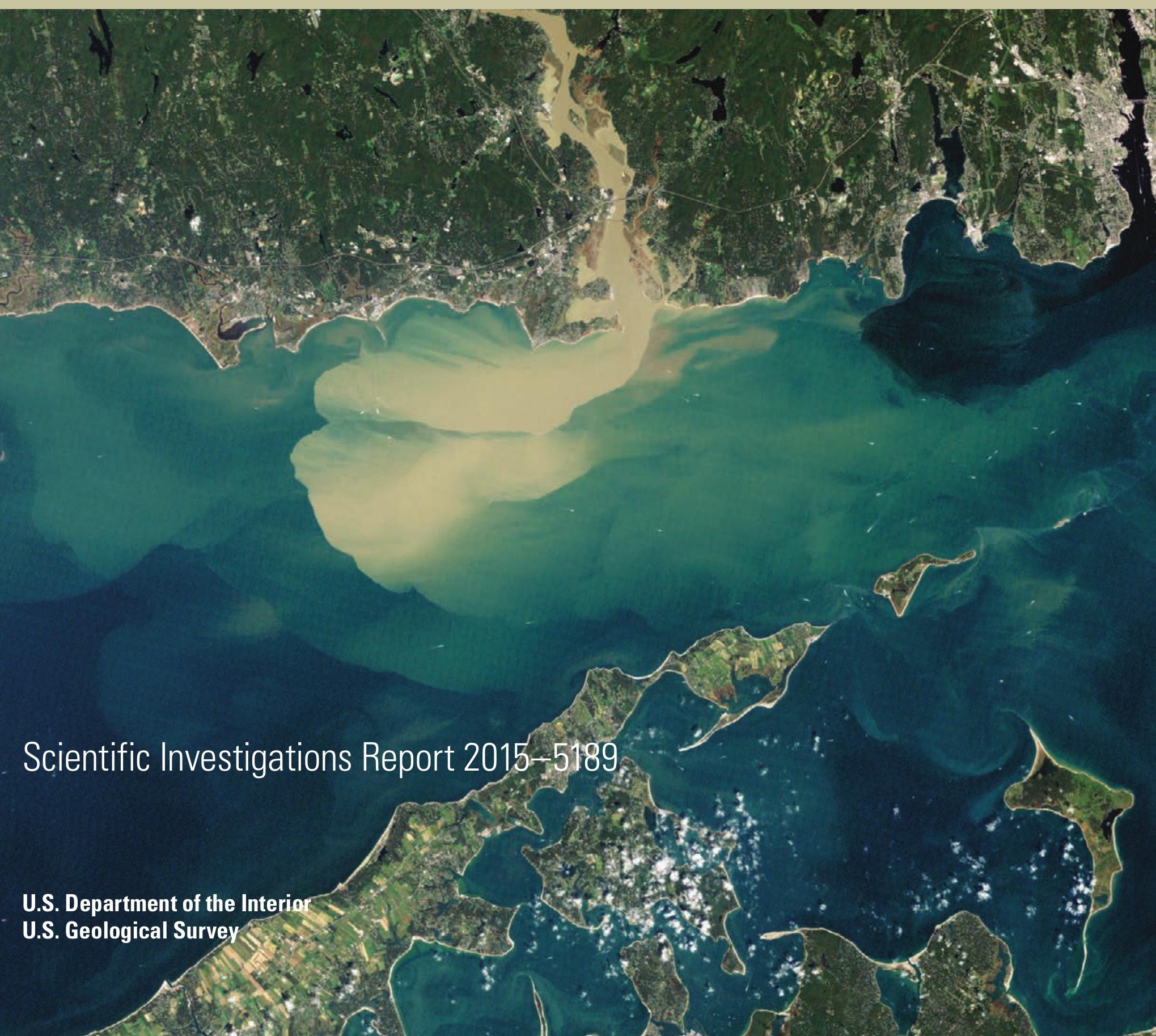


Cover. Sediment discharging from the Connecticut River into Long Island Sound on September 2, 2011, following heavy rains from Tropical Storm Irene. Photograph courtesy of NASA, from the Thematic Mapper on Landsat 5.

http://earthobservatory.nasa.gov/I0TD/view.php?id=52059 


\section{Nutrient, Organic Carbon, and Chloride Concentrations and Loads in Selected Long Island Sound Tributaries: Four Decades of Change Following the Passage of the Federal Clean Water Act}

By John R. Mullaney

Prepared in cooperation with the

Connecticut Department of Energy and Environmental Protection

Scientific Investigations Report 2015-5189 


\title{
U.S. Department of the Interior SALLY JEWELL, Secretary
}

\section{U.S. Geological Survey Suzette M. Kimball, Director}

\author{
U.S. Geological Survey, Reston, Virginia: 2016
}

For more information on the USGS - the Federal source for science about the Earth, its natural and living resources, natural hazards, and the environment-visit http://www.usgs.gov/ or call 1-888-ASK-USGS.

For an overview of USGS information products, including maps, imagery, and publications, visit http://www.usgs.gov/pubprod/.

Any use of trade, firm, or product names is for descriptive purposes only and does not imply endorsement by the U.S. Government.

Although this information product, for the most part, is in the public domain, it also may contain copyrighted materials as noted in the text. Permission to reproduce copyrighted items must be secured from the copyright owner.

Suggested citation:

Mullaney, J.R., 2016, Nutrient, organic carbon, and chloride concentrations and loads in selected Long Island Sound tributaries-Four decades of change following the passage of the Federal Clean Water Act: U.S. Geological Survey Scientific Investigations Report 2015-5189, 47 p., http://dx.doi.org/10.3133/sir20155189.

ISSN 2328-0328 (online) 


\section{Acknowledgments}

The author thanks Kelly Streich of the Connecticut Department of Energy and Environmental

Protection and Mark Tedesco of the U.S. Environmental Protection Agency, Long Island Sound Office for input on this manuscript. The author also thanks Laura Medalie, Robert Hirsch, and Lori Sprague of the U.S. Geological Survey for assistance with, and reviews of, this report. The author also would like to recognize the dedicated hydrologic technicians and hydrologists who have been collecting the water-quality data described in this report since 1973. 



\section{Contents}

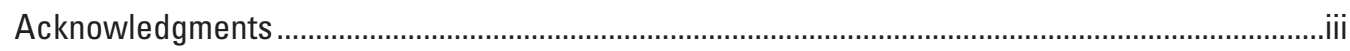

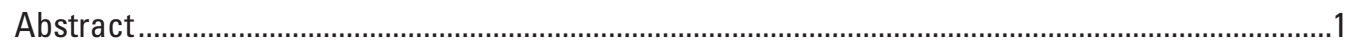

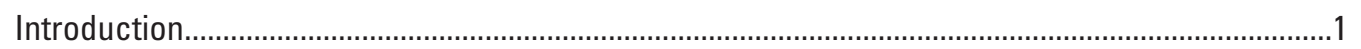

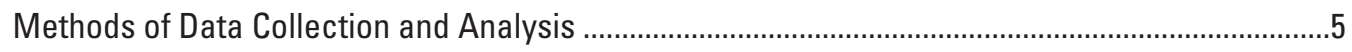

Water-Quality and Streamflow Data..................................................................................

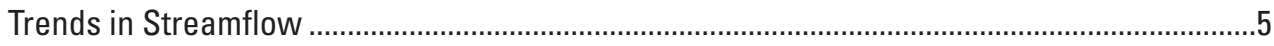

Use of the Smoothing Method in Flow History Analyses ...................................................6

Estimation of Concentration and Load ............................................................................

Estimation of Flow-Normalized Concentration and Load.........................................................

Changes in Streamflow, Water Years 1974-2013 and 2001-13................................................

Constituent Concentrations and Loads, Water Years 1974-2013 and 2001-13...............................11

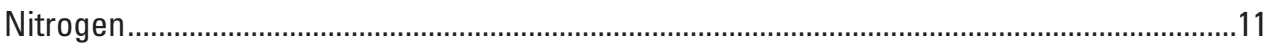

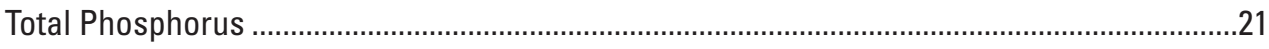

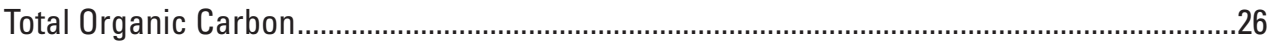

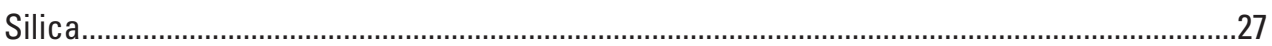

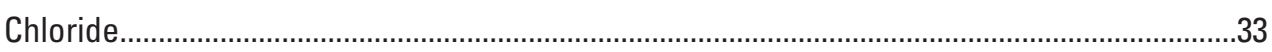

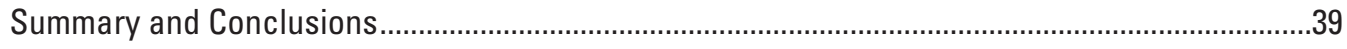

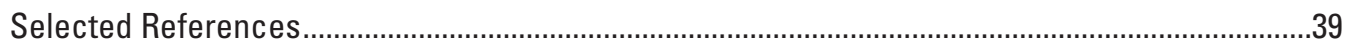

Appendix 1. Summary of Water-Quality Laboratory Method References for Samples Collected at Selected Streams in the Long Island Sound Basin, Water Years 1974-2013..................45

Appendix 2. Weighted Regressions on Time, Discharge, and Season Method Outputs..............47

\section{Figures}

1. Map showing monitoring sites on streams in the Long Island Sound Basin, Connecticut.

2. Graphs showing $A$, annual mean estimated and flow-normalized total nitrogen concentration and $B$, total annual estimated and flow-normalized total nitrogen load for selected sites in the Long Island Sound Basin in Connecticut, water years 1974-2013.

3. Graphs showing $A$, estimated annual mean and flow-normalized total Kjeldahl nitrogen concentration and $B$, estimated annual and flow-normalized total Kjeldahl nitrogen load at selected monitoring sites in the Long Island Sound Basin, Connecticut, water years 1974-2013.

4. Graphs showing $A$, estimated annual mean and flow-normalized nitrate plus nitrite nitrogen concentration and $B$, estimated annual and flow-normalized nitrate plus nitrite nitrogen load at selected monitoring sites in the Long Island Sound Basin, Connecticut, water years 1974-2013

5. Graphs showing mean wet deposition of $A$, inorganic nitrogen during 1981-2013 and $B$, nitrate and ammonium during 1985-2013 for the Long Island Sound Basin.........21

6. Graphs showing total nitrogen load, flow-normalized total nitrogen load, estimated wet deposition of inorganic nitrogen, and wastewater total nitrogen load upstream from selected monitoring sites in the Long Island Sound Basin, Connecticut, 1970-2013 
7. Graphs showing $A$, estimated annual mean and flow-normalized total phosphorus concentration and $B$, estimated annual and flow-normalized total phosphorus load at selected monitoring sites in the Long Island Sound Basin, Connecticut, water years 1974-2013.

8. Graph showing change in expected flow-adjusted total phosphorus concentrations in relation to streamflow by time of year, in the Connecticut River at Thompsonville monitoring site, in the Long Island Sound Basin, Connecticut, water years 1974-2013.27

9. Graphs showing $A$, estimated annual mean and flow-normalized total organic carbon concentration and $B$, estimated total annual and flow-normalized total organic carbon loads at selected monitoring sites in the Long Island Sound Basin, Connecticut, water years 1974-2013

10. Graphs showing $A$, estimated annual mean and flow-normalized dissolved silica concentrations and $B$, estimated annual flow-normalized dissolved silica loads at selected monitoring sites in the Long Island Sound Basin, Connecticut, water years 1974-2013.

11. Graph showing relation between percent of open water area in each basin and dissolved silica yields at selected monitoring sites in the Long Island Sound Basin, Connecticut, water years 2001-13.

12. Graphs showing $A$, estimated annual mean and flow-normalized chloride concentrations and $B$, estimated annual and flow-normalized chloride load at selected monitoring sites in the Long Island Sound Basin, Connecticut, water years 1974-2013.

13. Graphs showing change in expected flow-adjusted chloride concentrations and streamflow at selected sites in the Long Island Sound Basin, Connecticut, water years 1974-2013.

\section{Tables}

1. Description of basin characteristics for selected water-quality monitoring sites in the Long Island Sound Basin

2. Trends in annual and seasonal mean streamflow at selected monitoring sites in the Long Island Sound Basin, Connecticut, expressed in percent change, water years 1974-2013 and water years 2001-13.

3. Trends in annual and seasonal maximum daily streamflow at selected monitoring sites in the Long Island Sound Basin, Connecticut, expressed in percent change, water years 1974-2013 and water years 2001-13

4A. Change in flow-normalized concentration and flow-normalized load of total nitrogen at selected monitoring sites in the Long Island Sound Basin, Connecticut, water years 1974-2013 and 2001-13

4B. Change in flow-normalized concentration and flow-normalized load of Kjeldahl nitrogen at selected monitoring sites in the Long Island Sound Basin, Connecticut, water years 1974-2013 and 2001-13

4C. Change in flow-normalized concentration and flow-normalized load of nitrate plus nitrite nitrogen at selected monitoring sites in the Long Island Sound Basin, Connecticut, water years 1974-2013 and 2001-13

5. Land use, land cover, and land-use change in basins of selected monitoring sites in the Long Island Sound Basin, 1985-2010.

6. Change in flow-normalized concentrations and flow-normalized loads of total phosphorus at selected monitoring sites in the Long Island Sound Basin, Connecticut, water years 1974-2013 and water years 2001-13 
7. Change in flow-normalized concentrations and flow-normalized loads of total organic carbon at selected monitoring sites in the Long Island Sound Basin, Connecticut, water years 1974-2013 and water years 2001-13

8. Change in flow-normalized concentrations and flow-normalized loads of dissolved silica at selected monitoring sites in the Long Island Sound Basin, Connecticut, water years 1974-2013 and water years 2001-13.

9. Multiple linear-regression model variables used to describe variability in silica yields and the relation to selected land-cover/land-use characteristics . .34

10. Change in flow-normalized concentrations and flow-normalized loads of chloride at selected monitoring sites in the Long Island Sound Basin, Connecticut, water years 1974-2013 and water years 2001-13.

\section{Conversion Factors}

International System of Units to Inch/Pound

\begin{tabular}{|c|c|c|}
\hline Multiply & By & To obtain \\
\hline \multicolumn{3}{|c|}{ Length } \\
\hline meter $(\mathrm{m})$ & 3.281 & foot $(\mathrm{ft})$ \\
\hline \multicolumn{3}{|c|}{ Area } \\
\hline hectare (ha) & 2.471 & acre \\
\hline hectare (ha) & 0.003861 & square mile $\left(\mathrm{mi}^{2}\right)$ \\
\hline square kilometer $\left(\mathrm{km}^{2}\right)$ & 0.3861 & square mile $\left(\mathrm{mi}^{2}\right)$ \\
\hline \multicolumn{3}{|c|}{ Volume } \\
\hline cubic meter $\left(\mathrm{m}^{3}\right)$ & 0.0002642 & million gallons (Mgal) \\
\hline cubic meter $\left(\mathrm{m}^{3}\right)$ & 35.3107 & cubic foot $\left(\mathrm{ft}^{3}\right)$ \\
\hline \multicolumn{3}{|c|}{ Flow rate } \\
\hline cubic meter per second $\left(\mathrm{m}^{3} / \mathrm{s}\right)$ & 35.31 & cubic foot per second $\left(\mathrm{ft}^{3} / \mathrm{s}\right)$ \\
\hline cubic meter per second $\left(\mathrm{m}^{3} / \mathrm{s}\right)$ & 22.83 & million gallons per day (Mgal/d) \\
\hline \multicolumn{3}{|c|}{ Mass } \\
\hline $\begin{array}{l}\text { kilogram per hectare per year } \\
{[(\mathrm{kg} / \mathrm{ha}) / \mathrm{yr}]}\end{array}$ & 571.1 & $\begin{array}{l}\text { pounds per square mile per year } \\
{\left[\left(\mathrm{lb} / \mathrm{mi}^{2}\right) \mathrm{yr}\right]}\end{array}$ \\
\hline metric ton & 2,205 & pound (lb) \\
\hline kilogram (kg) & 2.205 & pound avoirdupois (lb) \\
\hline
\end{tabular}

Concentrations of chemical constituents in water are given in milligrams per liter (mg/L). 


\section{Abbreviations}

$\begin{array}{ll}\text { BNR } & \text { biological nitrogen removal } \\ \text { CI } & \text { chloride } \\ \text { CTDEEP } & \text { Connecticut Department of Energy and Environmental Protection } \\ \text { DSi } & \text { dissolved silica } \\ \text { EGRET } & \text { Exploration and Graphics for RivEr Trends } \\ \text { EPA } & \text { U.S. Environmental Protection Agency } \\ \text { LIS } & \text { Long Island Sound } \\ \text { LISS } & \text { Long Island Sound Study } \\ \text { NAWOA } & \text { National Water Quality Assessment } \\ \text { NWIS } & \text { National Water Information System } \\ \text { NO } & \text { nitrogen oxides } \\ \text { TKN } & \text { total Kjeldahl nitrogen } \\ \text { TMDL } & \text { total maximum daily load } \\ \text { TN } & \text { total nitrogen } \\ \text { TOC } & \text { total organic carbon } \\ \text { TP } & \text { total phosphorus } \\ \text { USGS } & \text { U.S. Geological Survey } \\ \text { WRTDS } & \text { Weighted Regressions on Time, Discharge, and Season } \\ \text { WWTF } & \text { wastewater treatment facility }\end{array}$




\title{
Nutrient, Organic Carbon, and Chloride Concentrations and Loads in Selected Long Island Sound Tributaries: Four Decades of Change Following the Passage of the Federal Clean Water Act
}

\author{
By John R. Mullaney
}

\section{Abstract}

Trends in long-term water-quality and streamflow data from 14 water-quality monitoring sites in Connecticut were evaluated for water years 1974-2013 and 2001-13, coinciding with implementation of the Clean Water Act of 1972 and the Connecticut Nitrogen Credit Exchange program, as part of an assessment of nutrient and chloride concentrations and loads discharged to Long Island Sound. In this study, conducted by the U.S. Geological Survey in cooperation with the Connecticut Department of Energy and Environmental Protection, data were evaluated using a recently developed methodology of weighted regressions with time, streamflow, and season. Trends in streamflow were evaluated using a locally weighted scatterplot smoothing method. Annual mean streamflow increased at 12 of the 14 sites averaging 8 percent during the entire study period, primarily in the summer months, and increased by an average of 9 percent in water years 2001-13, primarily during summer and fall months. Downward trends in flow-normalized nutrient concentrations and loads were observed during both periods for most sites for total nitrogen, total Kjeldahl nitrogen, nitrite plus nitrate nitrogen, total phosphorus, and total organic carbon. Average flow-normalized loads of total nitrogen decreased by 23.9 percent for the entire period and 10.9 percent for the period of water years 2001-13. Major factors contributing to decreases in flownormalized loads and concentrations of these nutrients include improvements in wastewater treatment practices, declining atmospheric wet deposition of nitrogen, and changes in land management and land use.

Loads of dissolved silica (DSi; flow-normalized and nonflow-normalized) increased slightly at most stations during the study period and were positively correlated to urbanized land in the basin and negatively correlated to area of open water. Concentrations and loads of chloride increased at 12 of the 14 sites during both periods. Increases likely are the result of an increase in the use of salt for deicing, as well as other factors related to urbanization and population growth, such as increases in wastewater discharge and discharge from septic systems.

\section{Introduction}

The streamflows from rivers in Connecticut that drain to Long Island Sound (LIS) are a major source of nitrogen and other nutrients that fuel seasonal hypoxia in LIS (New York State Department of Environmental Conservation and Connecticut Department of Environmental Protection, 2000). For this study, the Connecticut Department of Energy and Environmental Protection (CTDEEP) defines hypoxia as dissolved oxygen of less than 3.0 milligrams per liter $(\mathrm{mg} / \mathrm{L})$ in the water column of LIS. The area of hypoxia during the summer in LIS has averaged 464 square kilometers $\left(\mathrm{km}^{2}\right)$ since monitoring began in 1987, and the underlying recent trend in the areal extent of hypoxia is downward (Connecticut Department of Energy and Environmental Protection, 2013a). A number of changes related to land use and nutrient loading to LIS from these tributaries have occurred since the passage of the Federal Clean Water Act in 1972 (Public Law 92-500, 86 Stat. 816; 33 U.S.C. 1251 et seq.). Changes include increased development and population, as well as improvements to wastewater treatment, and decreased atmospheric wet deposition of nitrogen driven by decreases in oxidized nitrogen (Varekamp and others, 2014; Pinder and others, 2011).

The Long Island Sound Basin (fig. 1, inset) covers an area of $43,564 \mathrm{~km}^{2}$. The population within the LIS Basin increased from 8.03 million in 1970 to 8.9 million in 2010 (Long Island Sound Study, 2010); population increases occurred primarily in the lower or southern part of the basin. The amount of forested and agricultural land decreased in the lower LIS Basin, whereas areas of developed land and turf and grass increased. (New England Interstate Water Pollution Control Commission, 2014). Although the amount of farmland generally decreased, the number of farms increased. However, the use of commercial fertilizers on agricultural land decreased by 38 percent in Connecticut, 25 percent in Vermont, and 32 percent in New Hampshire during 1987-2007. In addition, the number of farm animals has decreased (New England Interstate Water Pollution Control Commission, 2014). From 1973 to about 1983, nearly all wastewater treatment facilities (WWTFs) in Connecticut were upgraded to secondary 
Concentrations and Loads in Long Island Sound Tributaries Following the Passage of the Federal Clean Water Act

treatment (Connecticut Department of Energy and Environmental Protection, undated).

In 1985, the Long Island Sound Study (LISS) was created to carry out a program to research, monitor, and assess the water quality of LIS in concert with the States of Connecticut and New York, forming a bistate partnership consisting of Federal and State agencies, user groups, nongovernmental organizations, and individuals dedicated to restoring and protecting LIS. In 2001, Connecticut and New York implemented a total maximum daily load (TMDL) to reduce the nitrogen load to LIS by 58.5 percent by 2014 (New York Department of Environmental Conservation and Connecticut Department of Environmental Protection, 2000), including a 64-percent reduction in nitrogen from WWTFs (Connecticut Department of Energy and Environmental Protection, 2013a). The LIS TMDL targeted reductions in nitrogen from point sources, such as WWTFs, and nonpoint sources, such as stormwater. The established wasteload allocation for nitrogen from WWTFs formed the basis for Connecticut's Nitrogen Credit Exchange (NCE), which was initiated in 2002 (Connecticut Department of Energy and Environmental Protection, 2013a).

As a result of the wasteload allocation and consequent upgrades at WWTFs, the goals for nitrogen reductions from WWTFs in Connecticut have been nearly achieved as of 2014. Planning and construction of upgrades at 12 additional WWTFs through 2018 are underway (Connecticut Department of Energy and Environmental Protection, 2014b).

As part of the reduction described above, the load allocation is based on achieving a 10-percent reduction in the total nonpoint source of nitrogen from urban and agricultural land. In Connecticut, a number of regulatory and nonregulatory programs have been established to directly or indirectly reduce nonpoint sources of nitrogen. These projects include stormwater permits, agricultural partnerships, combined-sewer overflow control, onsite wastewater permits, sanitary sewer extensions, and improved standards for development and redevelopment. The efficacy of these programs is difficult to measure; however, declines in stormwater nitrogen concentrations, which are recorded in the Connecticut Department of Energy and Environmental Protection (CTDEEP) industrial stormwater database, indicate improvements in stormwater quality during 1995-2011 (Connecticut Department of Energy and Environmental Protection, 2013c).

In this study, the method Weighted Regressions on Time, Discharge, and Season (WRTDS), developed by Hirsch and others (2010), was used to analyze trends in concentration and flux (load) of nutrients, organic carbon, and chloride $(\mathrm{Cl})$ at selected tributaries in the LIS Basin using long-term streamflow and water-quality records for 14 sites (fig. 1; table 1). The main focus of the research, which was conducted by the U.S. Geological Survey (USGS) in cooperation with the Connecticut Department of Energy and Environmental Protection, was to understand the changes to nitrogen load as a result of management action or land-use change since 1973, independent of random climate variability. The WRTDS method also was applied to other constituents of concern for either the freshwater tributaries or LIS, including total phosphorus (TP), total organic carbon (TOC), dissolved silica (DSi) and chloride $(\mathrm{Cl})$.

Phosphorus is not considered to be a limiting nutrient in LIS but is implicated in the impairment of at least 21 fresh waterbody segments in Connecticut, and Connecticut is mandated to establish limitations on phosphorus in all wastewater discharge permits where the discharge may contribute to impairments through eutrophication (Connecticut Department of Energy and Environmental Protection, 2014a). TOC and DSi were included in the analysis, as they are considered important constituents in LIS. Modeling associated with the TMDL development for LIS indicated that there are short time periods when silica limits algal growth. The oxidation of organic carbon is considered to be responsible for as much as 25 percent of the oxygen consumption in LIS; therefore, it was also considered in this study (New York State Department of Environmental Conservation and Connecticut Department of Environmental Protection, 2000). Chloride concentrations were analyzed using the WRTDS method in order to identify changes in concentrations and loads, an indicator of the effects of increasing urbanization with time.

The period of this study coincides with the passage of the Federal Clean Water Act of 1972 (Public Law 92-500, 86 Stat. 816; 33 U.S.C. 1251 et seq.), which established the basic structure for regulating discharges of pollutants into the waters of the United States and regulating quality standards for surface waters. Trend analyses in this report are provided for water years ${ }^{1}$ 1974-2013 and 2001-13, the latter period following the beginning of the NCE in Connecticut. General trends in streamflow were evaluated for this investigation because annual streamflow is the major factor in the magnitude of constituent load.

Water-quality data collected by the U.S. Geological Survey in Connecticut has been previously analyzed for trends in concentrations and loads of nitrogen and phosphorus (Trench and others, 2012; Sprague and others, 2009; and Trench and Vecchia, 2002). Nitrogen loads were previously estimated for these stations for varying periods of record by Mullaney and Schwarz (2013), Varekamp and others (2014), Trench and others (2012), Mullaney and others (2002), and Trench (2000). Several studies made flow-adjusted estimates of nutrient concentrations or loads (Trench and others, 2012; Sprague and others, 2009; and Varekamp and others, 2014). These methods typically were based on the assumption that trends over time are monotonic, and the relation between streamflow and concentration at a given site is constant with time. The WRTDS method differs in that there is no assumption that the mathematical shape or form of the relation between streamflow and concentration remains constant over the period of record (Hirsch and others, 2010).

In general, the studies listed above have concluded that total nitrogen (TN) and total phosphorus (TP) concentrations

\footnotetext{
${ }^{1} \mathrm{~A}$ water year is the 12 -month period beginning October 1 and ending September 30. It is designated by the year in which it ends.
} 


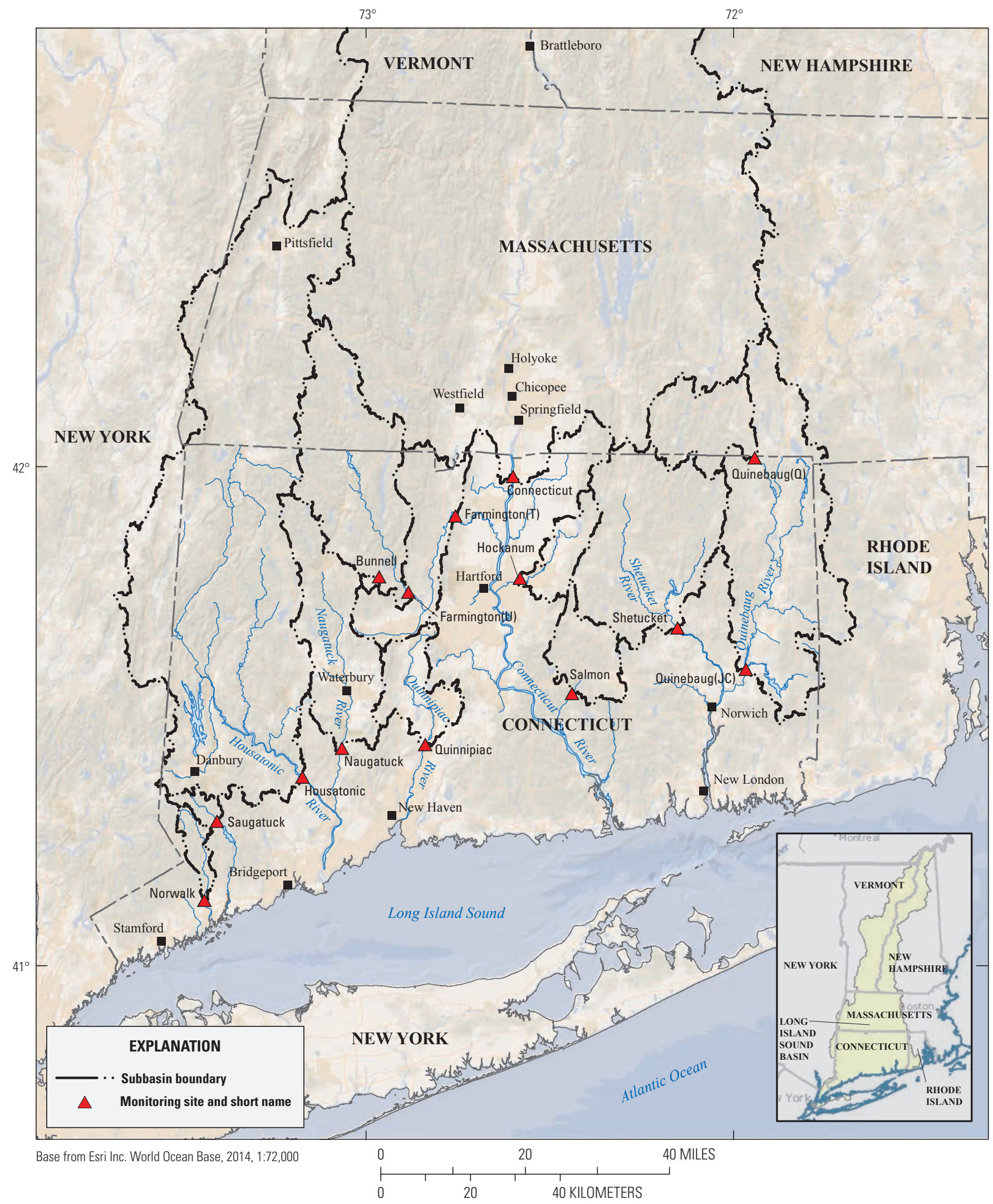

Figure 1. Monitoring sites on streams in the Long Island Sound Basin, Connecticut. 


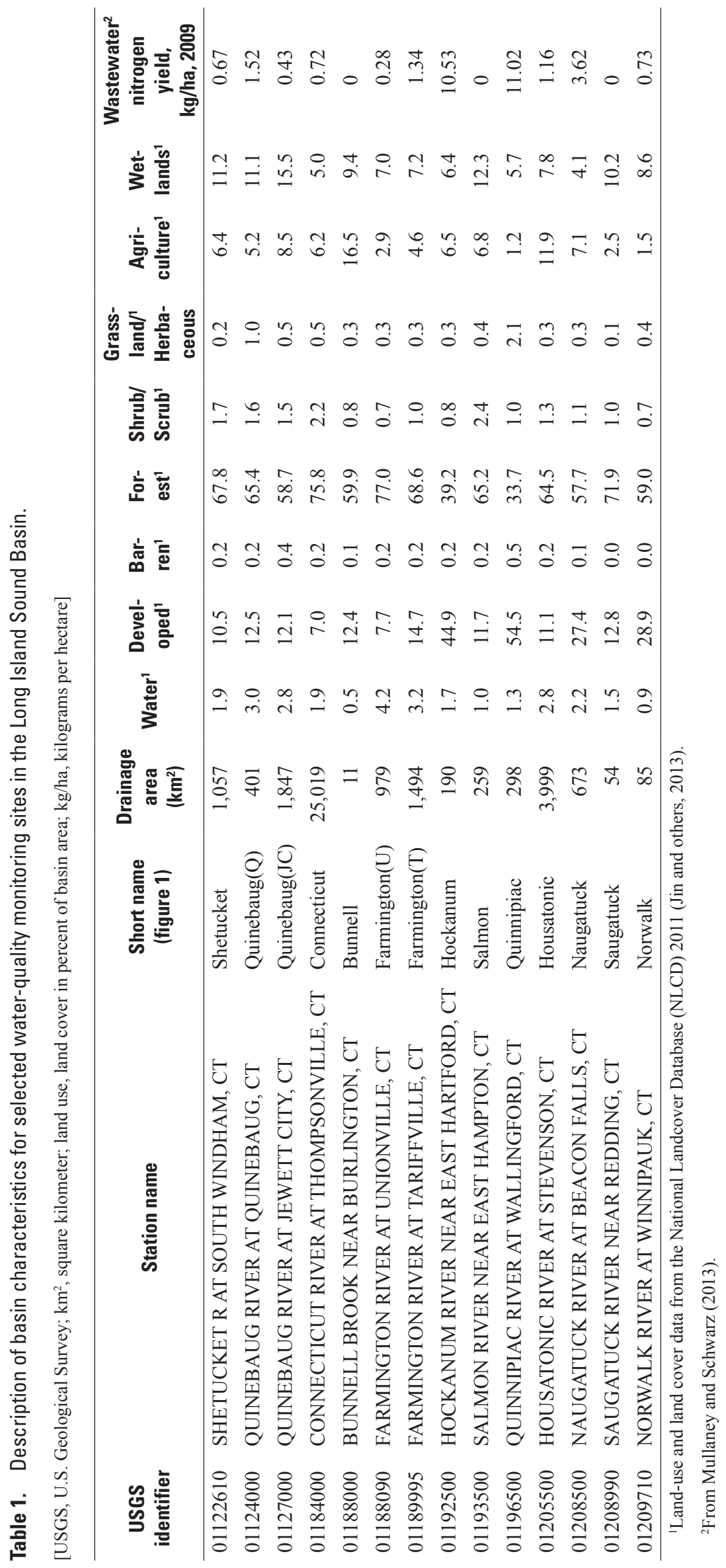


and loads have decreased in these tributaries over the long term since 1974 (Varekamp and others, 2014); however, Trench (1996) reports increases in TN concentrations during 1975-88 at 27 of 30 sites in Connecticut. Changes were attributed to increases in total organic nitrogen and nitrite plus nitrate nitrogen, possibly as a result of point discharges of nitrogen, nonpoint runoff, and atmospheric deposition.

Analysis of data from some of the sites in Connecticut with substantial point source discharges revealed increases in nitrite plus nitrate nitrogen and decreases in total ammonia during 1980-92, both of which indicate improved wastewater treatment practices, such as the transition from primary to secondary treatment, at that time (Zimmerman and others, 1996).

In an evaluation of TN loads in the LIS Basin, Mullaney and Schwarz (2013) provide estimates of the point and nonpoint total nitrogen loads to LIS. The analyses of Mullaney and Schwarz (2013) indicate that the estimated endof-pipe (point source) loads of total nitrogen from WWTFs had declined during water years 1999-2009, decreasing from about 44 percent of the estimated TN load to LIS in 1999 to about 27 percent of the TN load in 2009. Mullaney and Schwarz (2013) conclude that, for monitored and unmonitored tributaries to LIS during 1999-2009, TN loads from the tributaries to LIS (excluding most New York parts of the basin) were slightly increased or flat, likely owing to increases in streamflow toward the latter part of the record that offset major decreases in the TN load from wastewater treatment facilities. Fluctuations in annual streamflow likely conceal trends in nutrient loading as a result of management action or land-use change in the basin. This finding points to the need to adjust load and concentration estimates for variations in streamflow.

This report describes the changes in constituent concentrations and loads that occurred after the implementation of the Clean Water Act of 1972. Changes in concentrations and loads of nutrients, organic carbon, and chloride at 14 monitoring sites on streams in the Long Island Sound Basin in Connecticut are discussed. The study period extends from water years 1974 to 2013 with a subset of data from water years 2001 to 2013. The models used in the evaluation of water quality and streamflow are described.

\section{Methods of Data Collection and Analysis}

For evaluations of trends conducted in this study, the Exploration and Graphics for RivEr Trends (EGRET) package for the statistical software R (Hirsch and De Cicco, 2014) was used. The EGRET package consists of two modules - a Flow History analysis module and a module that computes Weighted Regressions of water-quality constituents on Time, Discharge, and Season (WRTDS). The underlying motivation and development of WRTDS are described in detail in Hirsch and others (2010). This method was previously used by
Sprague and others (2011) and Murphy and others (2013) for the Mississippi River Basin, and Medalie and others (2012) for the Lake Champlain Basin. WRTDS was recently used for analysis of $\mathrm{Cl}$ data in the northern United States by Corsi and others (2015).

The Flow History analysis was used to determine annual and seasonal changes in mean streamflow and maximum daily streamflow for water years 1974-2013 and 2001-13. For the same periods, the WRTDS module was used to estimate annual mean concentrations and loads of nitrogen species, TP, TOC, DSi, and $\mathrm{Cl}$, as well as annual mean concentrations and loads of these constituents adjusted for variations in streamflow (flow normalized).

\section{Water-Quality and Streamflow Data}

Water-quality and streamflow data for 14 sites in Connecticut for October 1, 1973, to September 30, 2013, (water years 1974-2013) were retrieved from the USGS National Water Information System (NWIS) for use in the EGRET package. These data were downloaded directly from USGS web services using the dataRetrieval package in R (http://usgs-r.github.io/). Streamflow data from station 01209710 (Norwalk) were calculated by multiplying 1.1 by the discharge at the upstream station 01209700.

Data on streamflow and water quality for these 14 sites, in general, have been collected periodically for several programs, including cooperative agreements between the USGS and the CTDEEP. Some historical data were collected for the USGS National Stream Accounting Network (NASQAN; Fick and Hawkinson, 1975) and the USGS National Water Quality Assessment (NAWQA) program (Gilliom and others, 1995). Data collection frequency varied by site and by constituent from a minimum of quarterly to more than 12 times per year. The references to the changes in laboratory methods for the constituents of interest are detailed in appendix 1.

The long-term monitoring sites (fig. 1; table 1) in this study are upstream from the tidal influence of LIS; consequently, nutrient loads downstream from these stations have not been measured by the USGS. The farthest downstream monitoring sites on the major rivers (Connecticut, Housatonic, Naugatuck, Quinnipiac, Shetucket, and Quinebaug) represent about 82 percent of the area draining to LIS from the north (excluding parts of New York; Varekamp and others, 2014).

\section{Trends in Streamflow}

Changes in streamflow during the study period (1974-2013) were evaluated to understand how changing streamflow conditions may have affected the loading of nutrients, TOC, and $\mathrm{Cl}$. This analysis helps to explain the differences among the observed and flow-normalized concentrations and loads presented in this report. Streamflow data for each station were evaluated for trends for water years 1974-2013 and water years 2001-13. Trend statistics include differences 
between annual mean streamflow for the two periods and during different seasons. The 1-day maximum streamflow (highest daily mean streamflow per year) also was evaluated for the periods of study.

\section{Use of the Smoothing Method in Flow History Analyses}

The EGRET package includes a Flow History module that builds on time-series smoothing methods pioneered by Cleveland (1979) and Cleveland and Devlin (1988). The method described here is modified from Rice and Hirsch (2012).

The Flow History analysis is designed for long records (ideally greater than 50 years) and performs smoothing on annual statistics relevant to annual low flow, high flow, or annual mean streamflow. For this discussion, the streamflow for year $i$ is defined as $Q_{i}$ where that streamflow can be any one of eight streamflow statistics (such a 7-day minimum, mean, or 1-day maximum) for the period of analysis. For any given year $i$ and streamflow $\left(Q_{i}\right)$ there is an associated time value $\left(T_{i}\right)$, which is expressed in decimal years. Thus, in a record of $\mathrm{n}$ years, for any given flow statistic and period of analysis there is a set of n values of $Q_{i}$ and $T_{i}$, which constitute the time series to be smoothed.

The smoothing method used is based on locally weighted scatterplot smoothing (LOWESS; Cleveland, 1979) modified as described below. The purpose of producing the smooth curves is to extract patterns of change that describe variations at time spans of about a decade or more. Such curves are very resistant to the influence of 1 or 2 years with extremely high or low flows. In those cases where the changes in streamflow are actually quite abrupt (for example, those caused by construction or removal of a dam or initiation of a major new water diversion), the curves will depict those changes as if they were gradual.

The variable $y_{i}$ is the log-transformed value of the flow statistic

$$
y_{i}=\ln \left(Q_{i}\right) .
$$

The logarithm transformation is applied because streamflow data typically are highly skewed, approximating a log-normal distribution in many cases. Use of the logarithm transformation results in weighted regressions in which the residuals are nearly normal, and thus, individual extreme values do not exert a large amount of influence on the estimates. This results in a more robust smoothing process. It also means that the smoothed values, denoted $Q_{i}$, are more nearly an approximation of the median of the time series than they are an approximation of the mean (see Helsel and Hirsch, 2002, p. 253-260, for a discussion of transformation issues).

In log-space, the smooth curve is defined by a series of $\mathrm{n}$-weighted regressions for the data set. The estimate, $\hat{y}_{i}$, of $y_{i}$ is defined as

$$
\hat{y}_{i}=\beta_{0 i}+\beta_{1 i} \times T,
$$

where

$$
\begin{aligned}
& i \quad \text { is equal to } 1 \text { to } n \text {, } \\
& \beta_{0 i} \quad \text { is the estimated regression intercept for the } \\
& \text { regression model fitted for year } i \text {, and } \\
& \beta_{1 i} \quad \text { is the estimated regression slope for the } \\
& \text { regression model fitted for year } i \text {. }
\end{aligned}
$$

The two regression coefficients $\beta_{0 i}$ and $\beta_{1 i}$ are computed from a weighted regression, where the weights are equal to 1 for the observation for the year in which the estimate is being made, and decay to zero at a time separation of $h_{i}$ years between the time of a given observation and the time of the estimate. The parameter $h_{i}$ is the half-window width used to complete the weights for the estimate $\hat{y}_{i}$. The EGRET software provides an option called edgeAdjust, which causes the window to become wider for years close to the start or end of the record and narrower for the middle years. This feature is new in the Flow History and WRTDS modules. Use of this option prevents the smoothed curve from having an excessive amount of curvature near the beginning or end of the record.

The nominal half-window width is defined as $H$. The default value of $H$ in this study was set to 20 years. Without the edgeAdjust feature, the actual half-window width for year $i$, denoted as $h_{i}$, is always equal to $H$. When the edgeAdjust feature is in effect, then the half-window width for the estimate for year $i$ is

$$
h_{i}=\max \left\{H, 2 H-\min \left(T_{i}-T_{1}, T_{n}-T_{i}\right)\right\},
$$

where

$$
\begin{aligned}
& T_{1} \quad \begin{array}{l}
\text { is the time value for the first year in the } \\
\text { record, }
\end{array} \\
& T_{n} \quad \begin{array}{l}
\text { is the time value for the last year in the } \\
\text { record, and }
\end{array} \\
& T_{i} \quad \begin{array}{l}
\text { is the time value of the year for which the } \\
\text { estimate is being made. }
\end{array}
\end{aligned}
$$

Note that, when $T_{i}$ is equal to the time of the first or last value, $h_{i}=2 H$.

The specific weights are computed with the tricubed weight function. The weight for the $j$ th streamflow value in the computation of the smoothed value for the $i$ th year is

$$
w_{i, j}=\left\{\begin{array}{cc}
\left(1-\left(\frac{\left|d_{i, j}\right|}{h_{i}}\right)^{3}\right)^{3} & \text { if }\left|d_{i, j}\right| \leq h_{i}, \\
0 & \text { if }\left|d_{i, j}\right| \geq h_{i}
\end{array}\right.
$$

where

$$
d_{i, j}=T_{i}-T_{j}
$$


The final step in producing the set of smoothed annual values is the retransformation

$$
\hat{Q}=\exp \left(\hat{y}_{i}\right)
$$

This retransformation is designed to produce a smooth representation of the median of the distribution over time for the statistic being plotted. For a comparison of two times, $T_{i}$ and $T_{j}$, (expressed in decimal years), for the smoothed values of streamflow at those times, $\hat{Q}_{i}$ and $\hat{Q}_{j}$, the changes were expressed as stated below.

- A change between the first and last year of the pair is expressed in the streamflow units selected.

$$
\hat{Q}_{j}-\hat{Q}_{i}
$$

- A change between the first and last year of the pair is expressed as a percentage of the value in the first year.

$$
\frac{\hat{Q}_{j}-\hat{Q}_{i}}{\hat{Q}_{i}} \times 100 .
$$

\section{Estimation of Concentration and Load}

The following description of the WRTDS method is an excerpt from Hirsch and De Cicco (2014). The WRTDS model can be thought of as a smooth surface that describes

$$
E[c]=w(Q, T)
$$

where

$\begin{aligned} c & \text { is concentration, in milligrams per liter; } \\ E[c] & \text { is the expected value of concentration; } \\ w & \text { is a function that depends on two variables; } \\ Q & \text { is streamflow, in cubic meters per second; and } \\ \mathrm{t} & \text { is time, in decimal years. }\end{aligned}$

Estimates of $E[c]$ are made as follows: A weighted regression model is estimated, and it takes the form

$$
\ln (c)=\beta_{0}+\beta_{1} q+\beta_{2} T+\beta_{3} \sin (2 \pi T)+\beta_{4} \cos (2 \pi T)+\varepsilon
$$

where

$c \quad$ is concentration, in milligrams per liter;

$\beta \quad$ is a regression coefficient;

$q$ is $\ln (Q)$, where $Q$ is daily mean streamflow, in cubic meters per second;

$T$ is time, in decimal years; and

$\varepsilon \quad$ is the error (unexplained variation).
It is important to recognize that although the form of the equation is written as if $\ln (\mathrm{c})$ is linear in $q$ and $T$ and varies seasonally as a perfect sine wave these properties hold true only locally. Because the coefficients vary throughout the $Q, T$ space, the linearity and sine wave form are free to change substantially over the entire $Q, T$ space. The estimation method assures that the estimates of $\ln (c)$ vary smoothly with $q$ and $T$ but are not constrained to linear or sine wave characteristics. The weights on each of the individual observations in the dataset are determined on the basis of three metrics of distance between the node and the specific observation: distance in time, distance in $q$, and distance in season, which is measured in units of years but considers only the fractional part of the time separation in years. Weights are associated with each of these three distance metrics by using the tricube weight function previously described. The half-window widths have default values of 2 (in log streamflow units), 7 years, and 0.5 years, which were used in this study.

The half-window width for time follows the same edgeAdjust convention as is described in the "Use of the Smoothing Method in Flow History Analyses" section, causing the half-window width to become wider for estimation points close to the beginning or end of the record. The overall weight for any observation is the product of the three weights, so a weight of zero for any of the three metrics results in an overall weight of zero. For any given node on the grid, the estimate of $\ln (c)$ is computed (by using the R function survReg, which is an implementation of "survival" or Tobit regression). In the EGRET code, this estimated value is known as $y$ Hat. In addition, the scale parameter of the survival regression is stored in the program for every node. The scale parameter is equivalent to a standard error (SE) of the residuals in an ordinary multiple regression. This error measure is known as SE in the EGRET code. To determine the expected value of $c$, the $y H a t$ value is multiplied by a bias correction factor (BCF) to account for the fact that the model is estimating $\ln (c)$ rather than estimating the concentration, and the errors in these estimates of $\ln (c)$ are assumed to be normally distributed. The $\mathrm{BCF}$ at each grid point is $\exp \left(\mathrm{SE}^{2} / 2\right)$. The third result that is stored, $E[c]$, is called concHat in the EGRET code. The three results are related by the formula

$$
\text { concHat }=B C F \times \exp (y H a t)
$$

An important distinction between WRTDS and other previously used models such as ESTIMATOR and LOADEST (Cohn and others, 1992; Runkel and others, 2004) is that, in these programs, the errors are assumed to be essentially constant across all seasons and streamflows, and consequently, the BCF used is virtually constant across all seasons and streamflows. The WRTDS model recognizes and uses these very substantial differences in the SE to compute the estimated concentrations. The WRTDS model uses the characterization of the $E[c]$ surface to make estimates of concentration for every day in the period of record. These individual daily estimates of concentration are made through a bi-linear interpolation of 
Concentrations and Loads in Long Island Sound Tributaries Following the Passage of the Federal Clean Water Act

the concHat value from the grid of estimates, using the values of $q$ and $T$ specific to that day. If the model assumptions of WRTDS were perfect, then these estimates would each be an unbiased estimate of concentration for that specific day. However, these estimates, taken in aggregate, will not exhibit as much variability as a real record would.

Each of these daily estimates of concentration is used to compute a daily estimate of load. Load for each day, in units of kilograms per day, is computed as

$$
\text { concHat } \times Q \times 86.4 \text {, }
$$

where

$$
\begin{aligned}
& \text { concHat is the daily estimate of concentration, in } \\
& \text { milligrams per liter; } \\
& Q \quad \text { is the daily mean streamflow, in cubic meters } \\
& \text { per second; and }
\end{aligned}
$$

\section{Estimation of Flow-Normalized Concentration and Load}

The variability in concentration or load that stems from variability in streamflow can overwhelm the signal of change attributable to management actions. Streamflow-driven variability creates a large amount of apparent "noise," thus making the identification of a trend difficult. The method used to neutralize the noise in WRTDS is termed "flow normalization." The flow-normalization process removes the year to year variation owing to flow variations, but the validity is based on the idea that streamflow is stationary over the period of record.

It can be described in the following manner:

$$
E\left[C_{f n}(T)\right]=\int_{0}^{\infty} w(Q, T) \times f_{T_{s}}(Q) d Q
$$

where

$$
\begin{aligned}
& E\left[C_{f n}(T)\right] \quad \text { is the flow-normalized concentration for time } \\
& T \text { (a specific day of a specific year), } \\
& w(Q, T) \quad \text { is the WRTDS estimate of concentration as a } \\
& \text { function of } Q \text { (streamflow) and } T \text { (time, in } \\
& \text { years), and } \\
& f_{T_{s}}(Q) \quad \text { is the probability density function of } \\
& \text { streamflow specific to a particular time of } \\
& \text { year, designated as } T_{s} \text {. }
\end{aligned}
$$

The $T_{S}$ parameter is restricted to values between 0 and 1 , and it is defined as the fractional part of the time variable $T$ (thus $T_{S}$ is the decimal portion of decimal year). Thus, the flow-normalized concentration on a specific day (a specific value of $T$ ) is the integral of the fitted estimates of concentration as a function of streamflow and time multiplied by the probability density function of streamflow for that day of the year. The challenge to operationalizing this function is the specification of the probability density function of streamflow for each day of the year. In WRTDS, this starts with the assumption that for any given day of the year the distribution of streamflow is stationary.

The flow-normalized load is computed similarly, where the random variable of interest is load rather than concentration.

$$
E\left[F_{f n}(T)\right]=\int_{0}^{\infty} Q \times 86.4 \times w(Q, T) \times f_{T_{s}}(Q) d Q
$$

where $E\left[F_{f n}(T)\right] \quad$ is the flow-normalized concentration for time
$T$ (a specific day of a specific year).

Changes in flow-normalized concentration and load from water years 1974 (or later depending on the site) to 2013 or 2001 to 2013 are expressed as the difference in flow-normalized concentrations or loads, as well as the percent change for the specified time period.

\section{Changes in Streamflow, Water Years 1974-2013 and 2001-13}

Annual mean streamflows generally increased at most sites for water years 1974-2013, averaging about 8 percent. Two rivers (Quinebaug (JC) and the Naugatuck) had decreases in annual mean streamflows. For the statistical analyses, seasons were defined as winter (December, January, February), spring (March, April, May), summer (June, July, August) and fall (September, October, November). For water years 2001-13, there were increases in annual mean streamflows at all sites studied, averaging about 9 percent. Increases were consistent and, in general, greatest during the summer and fall seasons for both periods (table 2).

Data on annual and seasonal maximum daily streamflows were evaluated for water years 1974-2013 and 2001-13. Maximum daily streamflow represents that day of the year or day of a season within the year with the largest mean daily streamflow. There was a mix of increases and decreases in annual maximum streamflow for 1974-2013, depending on the station. The winter season was dominated by decreases, whereas spring, fall, and particularly summer had increases in maximum daily streamflow (table 3 ). For water years 2001-13, the maximum daily streamflow increased at all sites, except for the Connecticut river site, averaging 21.6 percent. Maximum daily streamflow increased at most of the sites during the winter, spring and summer seasons.

Increases in summer streamflows may be attributable to increases in summer precipitation for this region, as reported by Hodgkins and Dudley (2011). In addition, increases in summer streamflows may be attributable to increased urbanization in some of these basins, which includes increases in wastewater discharge, impervious cover, and streamflow regulation. Summer streamflows are likely important for providing nutrients to LIS during the season when hypoxia is most prevalent; 
Table 2. Trends in annual and seasonal mean streamflow at selected monitoring sites in the Long Island Sound Basin, Connecticut, expressed in percent change, water years 1974-2013 and water years 2001-13.

\begin{tabular}{lccccccc}
\hline \multicolumn{1}{c}{ Station } & $\begin{array}{c}\text { Beginning } \\
\text { water year }\end{array}$ & $\begin{array}{c}\text { Ending } \\
\text { water year }\end{array}$ & Annual & Winter & Spring & Summer & Fall' \\
\hline Shetucket & 1974 & 2013 & 2.5 & -11 & -1.3 & 36 & -7.4 \\
Quinebaug(Q) & 1974 & 2013 & 8.4 & 0.19 & -5.4 & 33 & 6.7 \\
Quinebaug(JC) & 1974 & 2013 & -4.4 & -16 & -10 & 12 & -7.7 \\
Connecticut & 1974 & 2013 & 12 & 19 & -8.7 & 45 & 24 \\
Bunnell & 1974 & 2013 & 12 & 1.1 & -7.1 & 64 & 45 \\
Farmington(U) & 1978 & 2013 & 29 & 45 & 1.1 & 23 & 52 \\
Farmington(T) & 1974 & 2013 & 9.7 & 13 & -11 & 24 & 21 \\
Hockanum & 1977 & 2013 & 20 & 19 & 1.9 & 34 & 41 \\
Salmon & 1974 & 2013 & 3.7 & -16 & -0.56 & 41 & 6.1 \\
Quinnipiac & 1974 & 2013 & 10 & 3.8 & -1.7 & 30 & 27 \\
Housatonic & 1974 & 2013 & 11 & 12 & -16 & 38 & 52 \\
Naugatuck & 1974 & 2013 & -3.3 & -14 & -18 & 28 & 18 \\
Saugatuck & 1974 & 2013 & 0.82 & -6.1 & -12 & 25 & 20 \\
Norwalk & 1974 & 2013 & 0.43 & -5.3 & -10 & 25 & 14 \\
\hline
\end{tabular}

${ }^{1}$ Fall analysis for water years 1975 or later to 2012.

\begin{tabular}{lccccccc}
\hline \multicolumn{1}{c}{ Station } & $\begin{array}{c}\text { Beginning } \\
\text { water year }\end{array}$ & $\begin{array}{c}\text { Ending } \\
\text { water year }\end{array}$ & Annual & Winter & Spring & Summer & Fall $^{2}$ \\
\hline Shetucket & 2001 & 2013 & 5.8 & 1.5 & -1.1 & 20 & 1.1 \\
Quinebaug(Q) & 2001 & 2013 & 8.1 & 6.6 & -4.1 & 22 & 8.7 \\
Quinebaug(JC) & 2001 & 2013 & 4.1 & -0.24 & -3.7 & 17 & 4.1 \\
Connecticut & 2001 & 2013 & 8.6 & 10 & -1.5 & 20 & 15 \\
Bunnell & 2001 & 2013 & 8.7 & 8.3 & -3.7 & 27 & 13 \\
Farmington(U) & 2001 & 2013 & 15 & 18 & 2 & 16 & 15 \\
Farmington(T) & 2001 & 2013 & 10 & 13 & -0.81 & 14 & 11 \\
Hockanum & 2001 & 2013 & 10 & 5.9 & 3.6 & 17 & 12 \\
Salmon & 2001 & 2013 & 9.8 & 4 & 4.7 & 21 & 2.7 \\
Quinnipiac & 2001 & 2013 & 9.7 & 9.8 & 3.3 & 17 & 12 \\
Housatonic & 2001 & 2013 & 11 & 12 & -3.9 & 19 & 20 \\
Naugatuck & 2001 & 2013 & 6.4 & 6.7 & -4.1 & 17 & 11 \\
Saugatuck & 2001 & 2013 & 11 & 12 & 3.1 & 14 & 14 \\
Norwalk & 2001 & 2013 & 9.4 & 10 & 0.3 & 19 & 16 \\
\hline
\end{tabular}

${ }^{2}$ Fall analysis for water years 2001-12. 
Table 3. Trends in annual and seasonal maximum daily streamflow at selected monitoring sites in the Long Island Sound Basin, Connecticut, expressed in percent change, water years 1974-2013 and water years 2001-13.

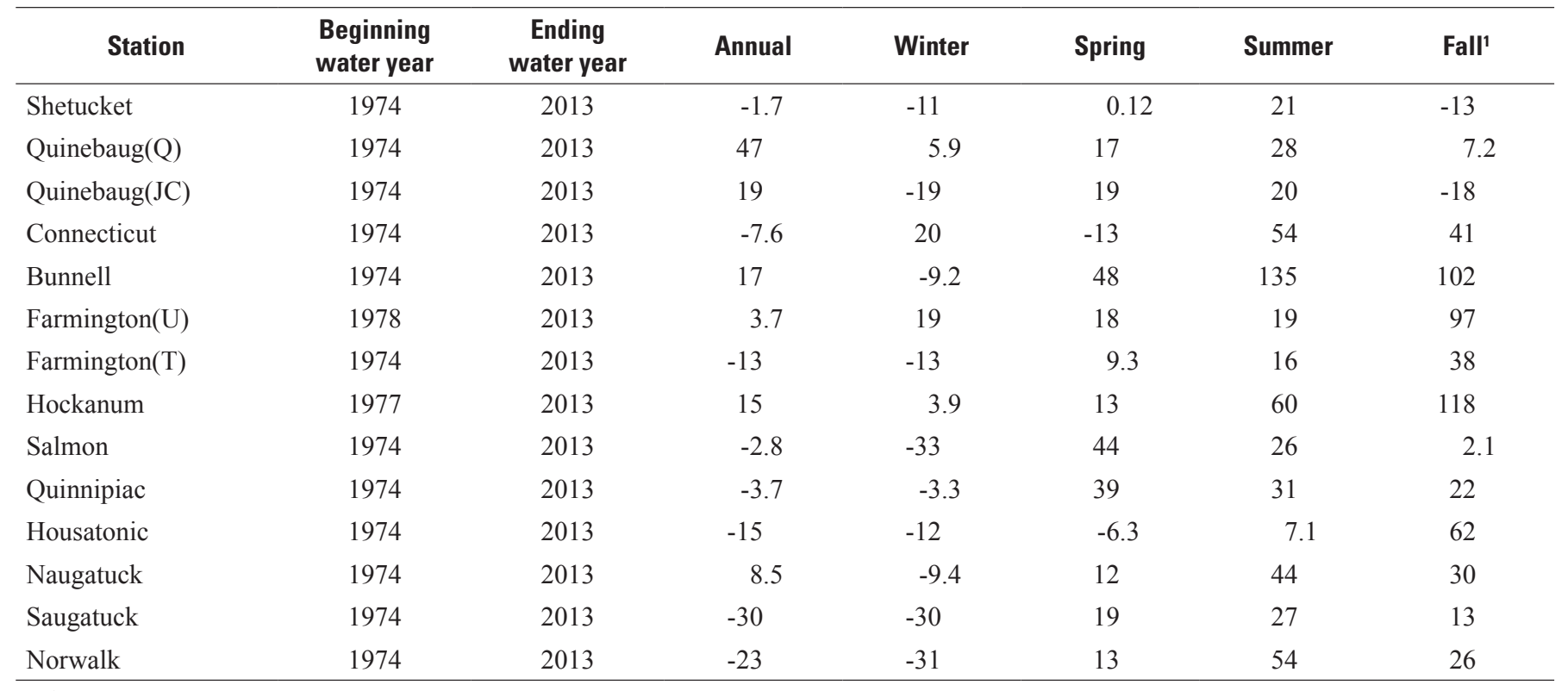

${ }^{1}$ Fall analysis for water years 1975 or later to 2012.

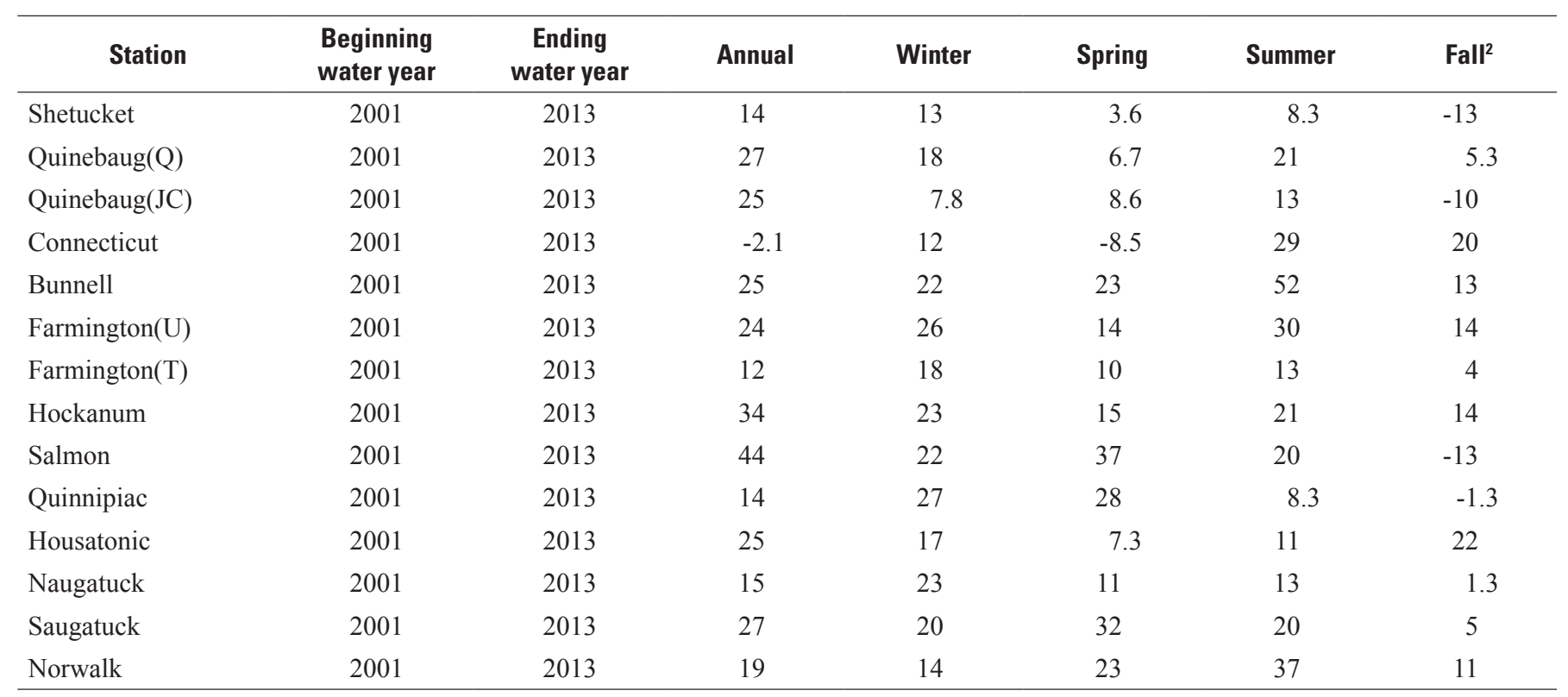

${ }^{2}$ Fall analysis for water years 2001-12. 
therefore, increases in streamflow and associated loading of nutrients during this period may be an important predictor of the annual severity of hypoxia.

Maximum daily streamflow is likely representative of stormflow and consequently is important for the transport of nutrients associated with stormwater runoff and suspended sediments, such as TP and total Kjeldahl nitrogen (TKN). Therefore, increased maximum daily streamflow (particularly for water years 2001-13) may be important in the delivery of nonpoint source nutrient loads. Increased maximum streamflows also have the potential to increase the frequency of combined sewer overflows (CSOs), which are a substantial nutrient source for some parts of the study area, particularly for the Connecticut site, and the Naugatuck site. CSO discharges in many locations have been reduced and eliminated in Connecticut, Massachusetts, and New Hampshire since the 1970s, and more upgrades are planned (Commonwealth of Massachusetts, Department of Environmental Protection, 2013; Connecticut Department of Energy and Environmental Protection, 2013c; New Hampshire Department of Environmental Services, 2013). Because of these identified trends in streamflow and the assumption of stationarity in the streamflow records using the previously defined methodology, it is important to continue to track the non-flow-normalized loads for further confirmation that the observed trends are real and not an artifact of some long-term change in streamflow.

\section{Constituent Concentrations and Loads, Water Years 1974-2013 and 2001-13}

\section{Nitrogen}

Total nitrogen (including flow-normalized and non-flownormalized) concentrations at monitoring sites evaluated in this study have generally decreased for water years 1974-2013 and 2001-13 (fig. 2; table 4). The flow-normalized loads of TN have decreased at most of the sites studied for these periods, averaging 23.9 percent for 1974-2013 and 10.9 percent for 2001-13. Non-flow-normalized loads generally decreased at most sites; however, some years had large loads, for example water years 2006 and 2011, when annual streamflows were extremely high. In samples from the Quinebaug (Q), Norwalk, and Farmington (U) sites, TN concentrations and loads decreased dramatically during the first part of the record and then nearly leveled off. A contrasting effect was seen for TN at the Quinnipiac and Naugatuck sites, where concentrations and loads decreased dramatically near the end of the record.

Total nitrogen loads at many of the stations were higher toward the end of the record in 2013 than they were during 2000-01. The flow-normalized concentrations and loads generally decreased since the beginning of the study period at most sites, indicating that management action and other factors independent of streamflow may be related to decreases in concentrations and loads. Changes in flow-normalized concentrations and loads of TKN and nitrogen oxides $\left(\mathrm{NO}_{\mathrm{x}}\right)$ are similar to those observed for TN (figs. 3 and 4; table $4 \mathrm{~A}-\mathrm{C}$ ). Flow-normalized concentrations and loads of TN, TKN, and $\mathrm{NO}_{x}$ (primarily nitrate $\left[\mathrm{NO}_{3}^{-}\right]$) decreased at the sites receiving flow from upstream wastewater treatment facilities (table 1) during both periods, whereas they increased slightly at four sites (Bunnell, Salmon, Saugatuck, Norwalk) in basins with little development and little or no wastewater discharges. These increases in flow-normalized concentrations are small in magnitude and may be better analyzed using a bootstrap test, which is under development for WRTDS (Robert Hirsch, U.S. Geological Survey, written commun., April 2015).

Flow-normalized concentrations and loads of TN, which at many stations were highest during the early 1980 s, may have some high bias owing to the analytical and processing methods used at the time. TN in this study was determined from the sum of TKN and $\mathrm{NO}_{\mathrm{x}}$ in individual samples. A positive bias of $0.1 \mathrm{mg} / \mathrm{L}$ of TKN was reported for data analyzed by the USGS National Water Quality Laboratory from 1986 to 1991 . Concentrations of nitrates greater than $1 \mathrm{mg} / \mathrm{L}$ may bias TKN values either low or high using this method. (Patton and Truitt, 2000; Trench and others, 2012). The effects of these potential biases could be large for sites with low TN concentrations and probably are small for sites with high TN concentrations.

A number of factors likely have influenced TN loads and concentrations during the study. A major factor in the early part of the study period was upgrades to secondary treatment at WWTFs in Connecticut following the passage of the Federal Clean Water Act in 1972 (Public Law 92-500, 86 Stat. 816; 33 U.S.C. 1251 et seq.). These upgrades were largely completed by 1990 in Connecticut (Rowland Denny, Connecticut Department of Energy and Environmental Protection, written commun., November 2014).

Eighteen WWTFs in Connecticut (as of 2013) that are upstream from the monitoring sites evaluated for this study were upgraded to biological nitrogen removal (BNR). These upgrades were performed as part of implementation of the LIS TMDL (finalized in 2001). Additionally, minor operational changes to improve BNR (low cost retrofits) have been made at other WWTFs in order to reduce nitrogen load (Rowland Denny, Connecticut Department of Energy and Environmental Protection, written commun., November 2014). In 1977, the WWTF at Springfield, Massachusetts, was upgraded to include secondary treatment; other upgrades were made in 1988 and 1997-99 (Douglas Borgatti, Operations Director, Springfield Water and Sewer Commission, written commun., 2011). The Springfield facility contributes about one-third of the wastewater volume that discharges into the Connecticut River upstream from the Connecticut river site. Concentrations of nitrogen in treated wastewater measured after these upgrades were completed were low, relative to typical wastewater, with a mean $\mathrm{TN}$ concentration of $5 \mathrm{mg} / \mathrm{L}$ during 2002-05 (Deacon and others, 2006). 

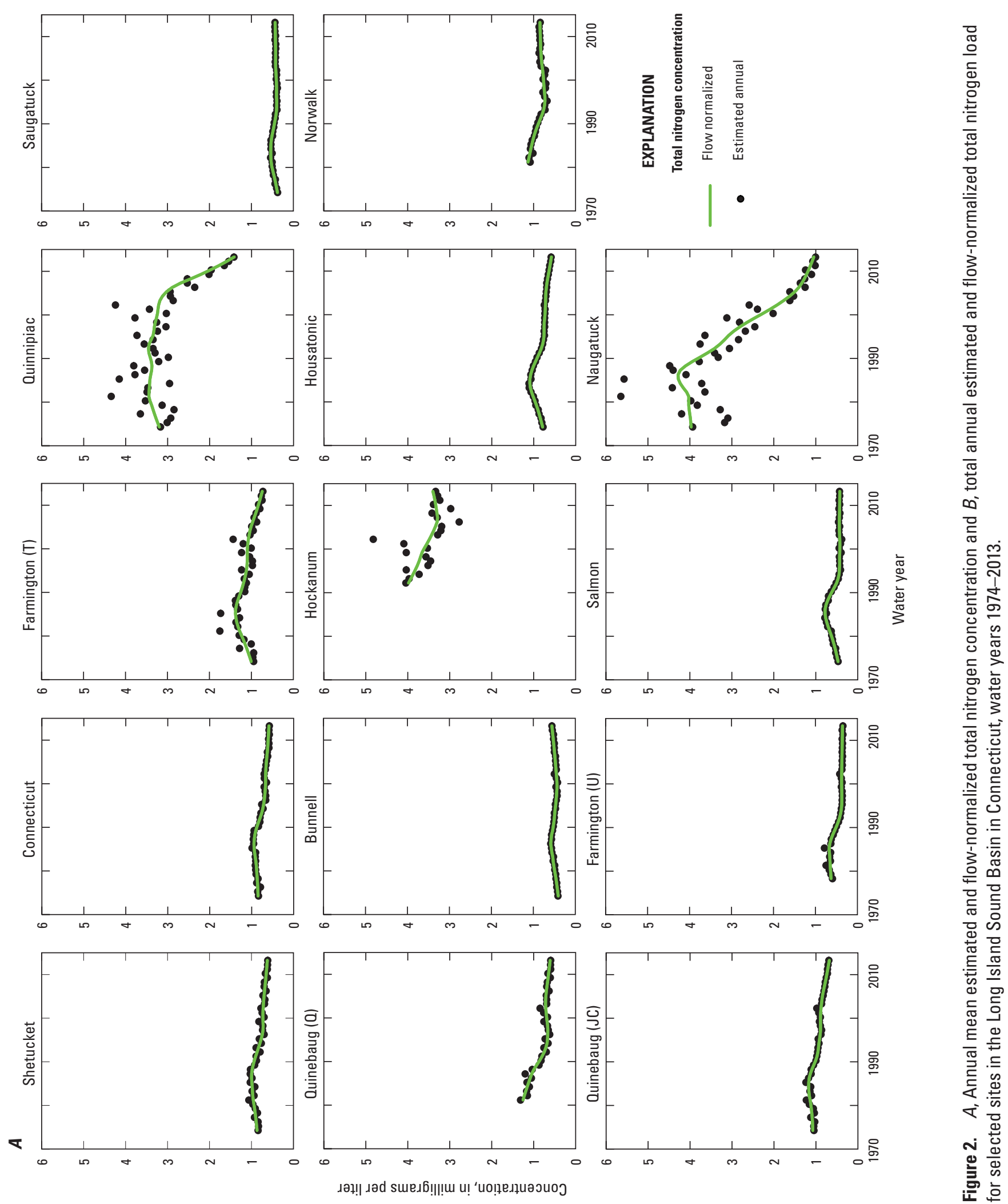

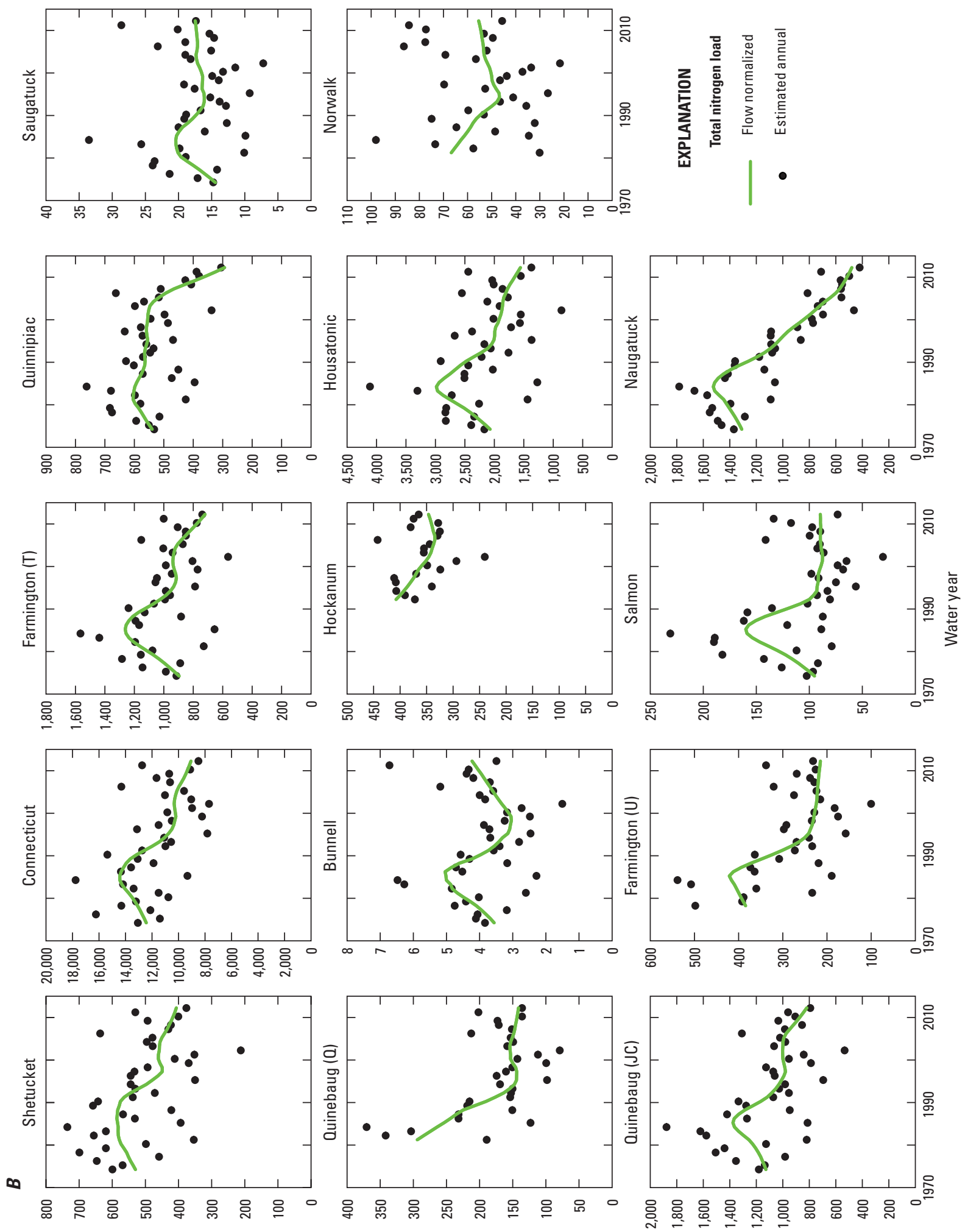

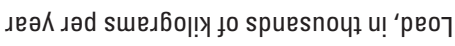

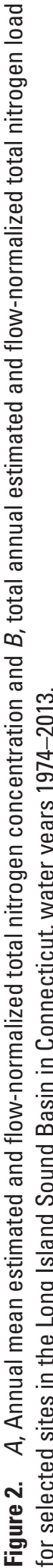



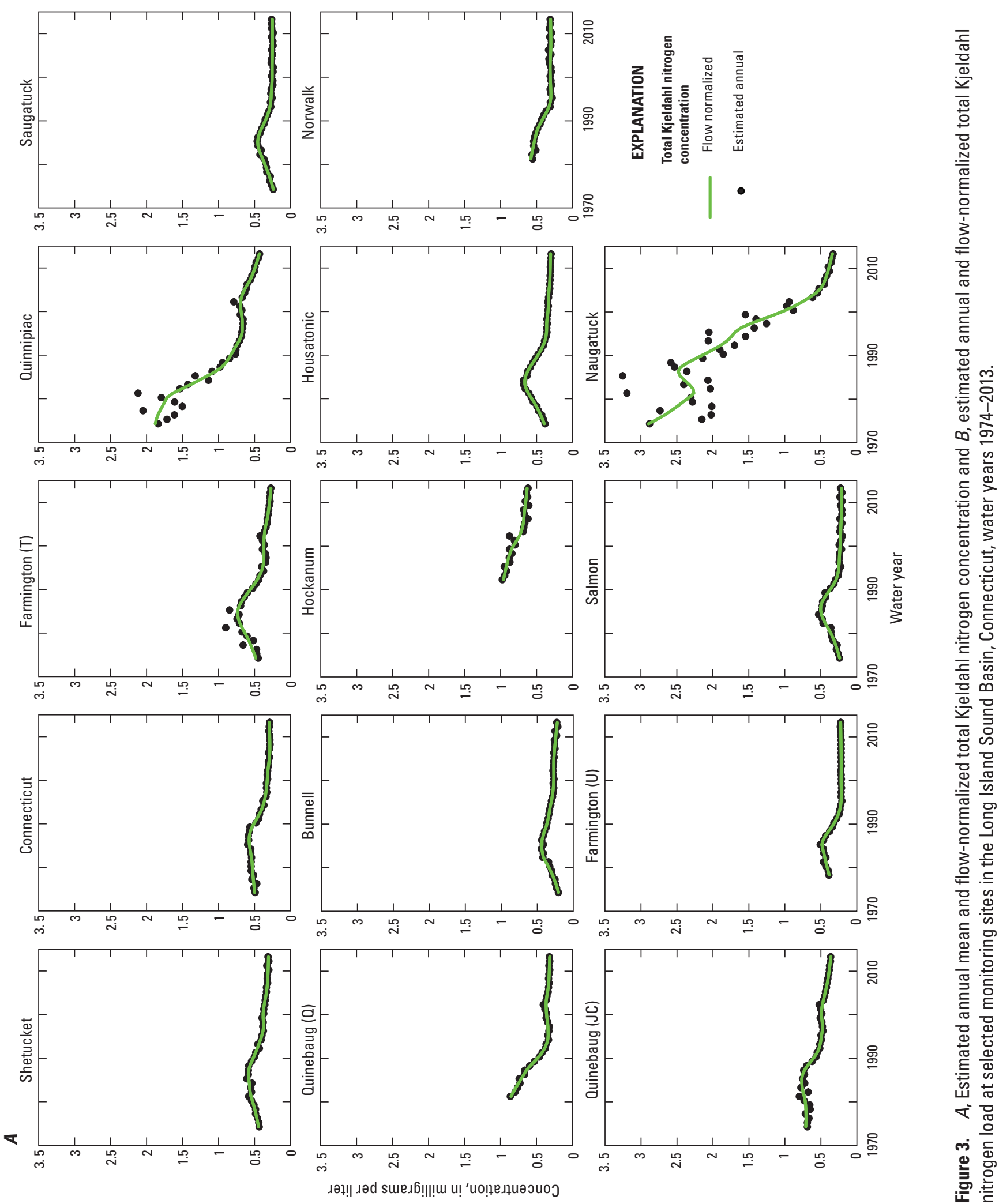

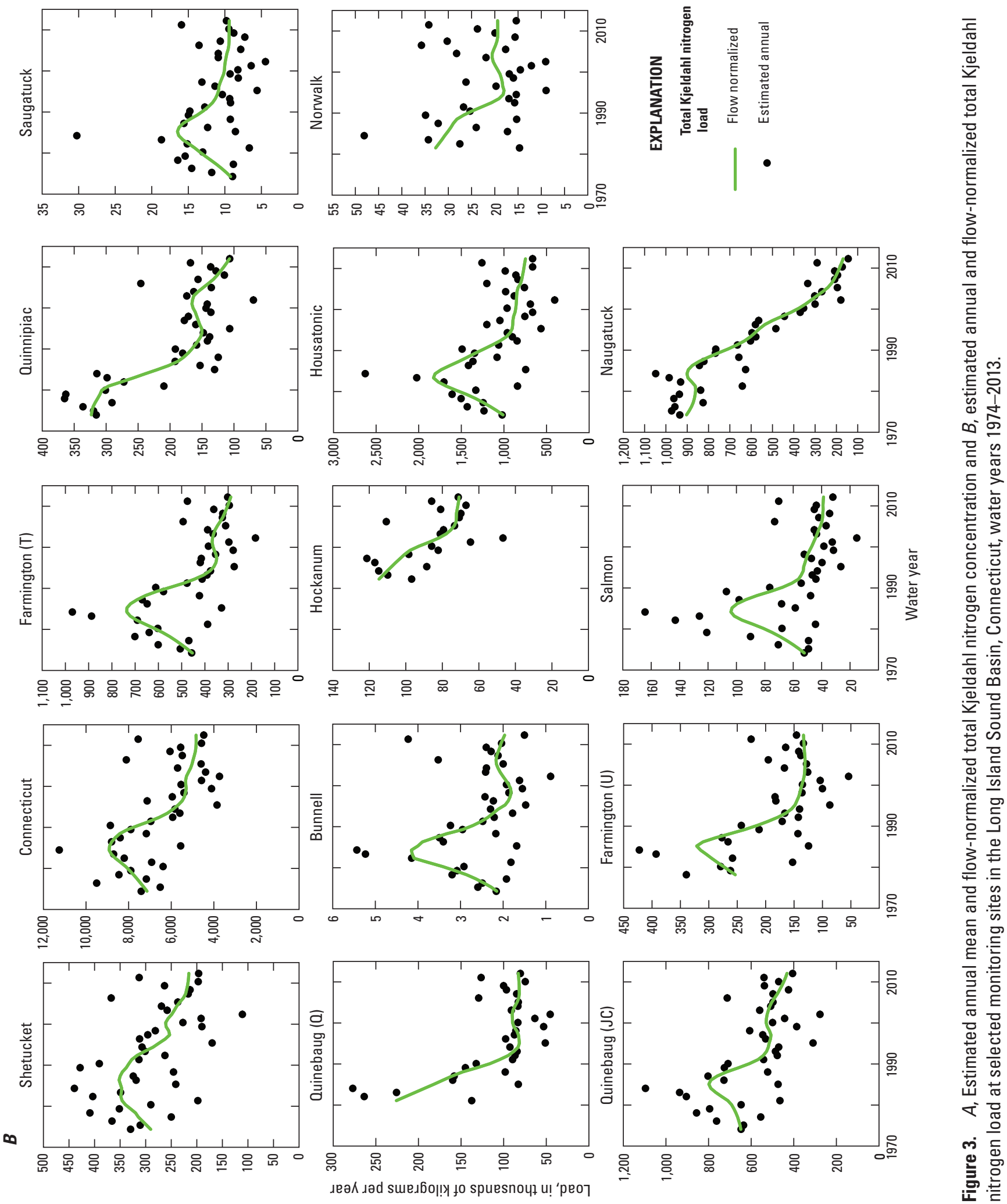

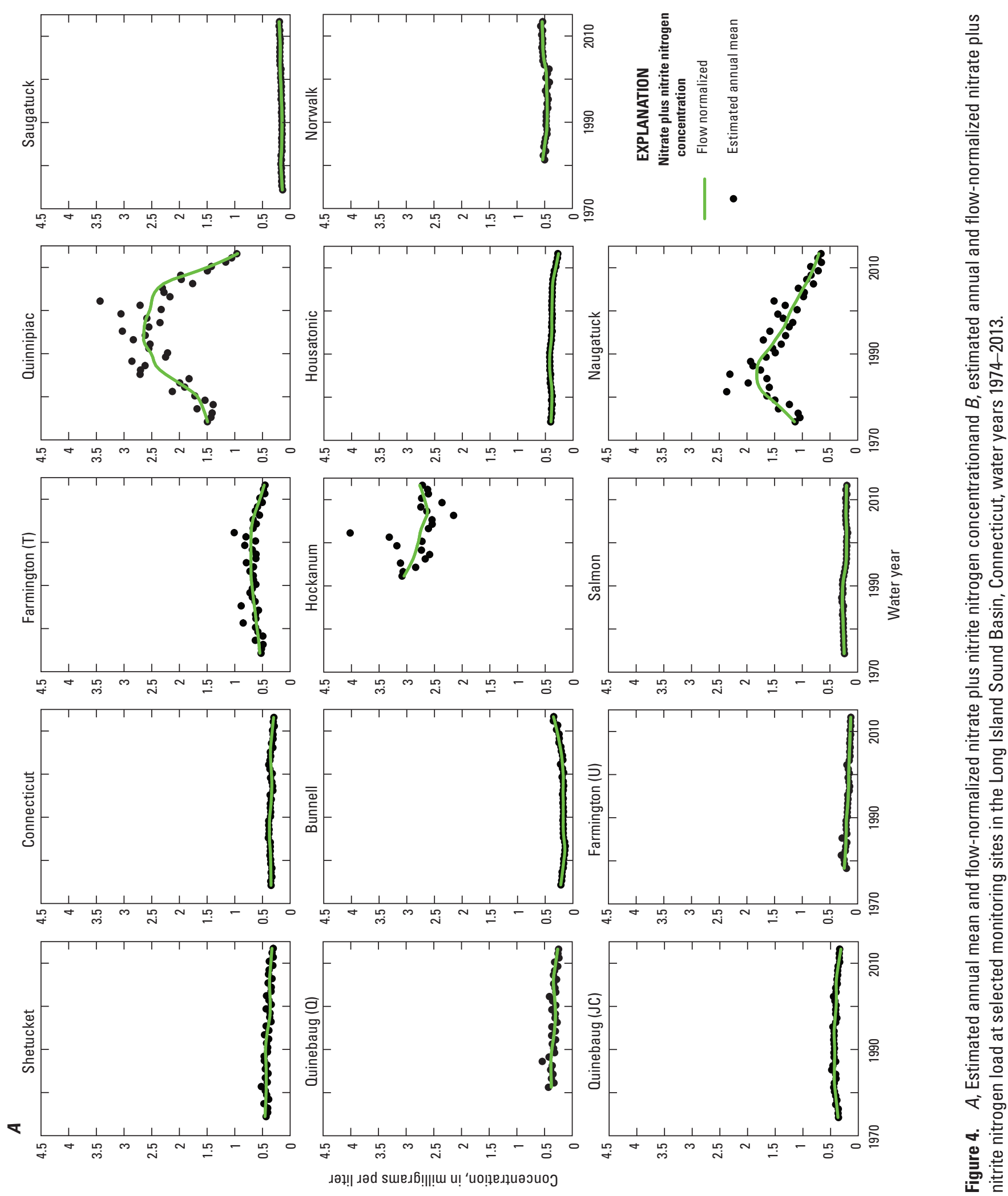

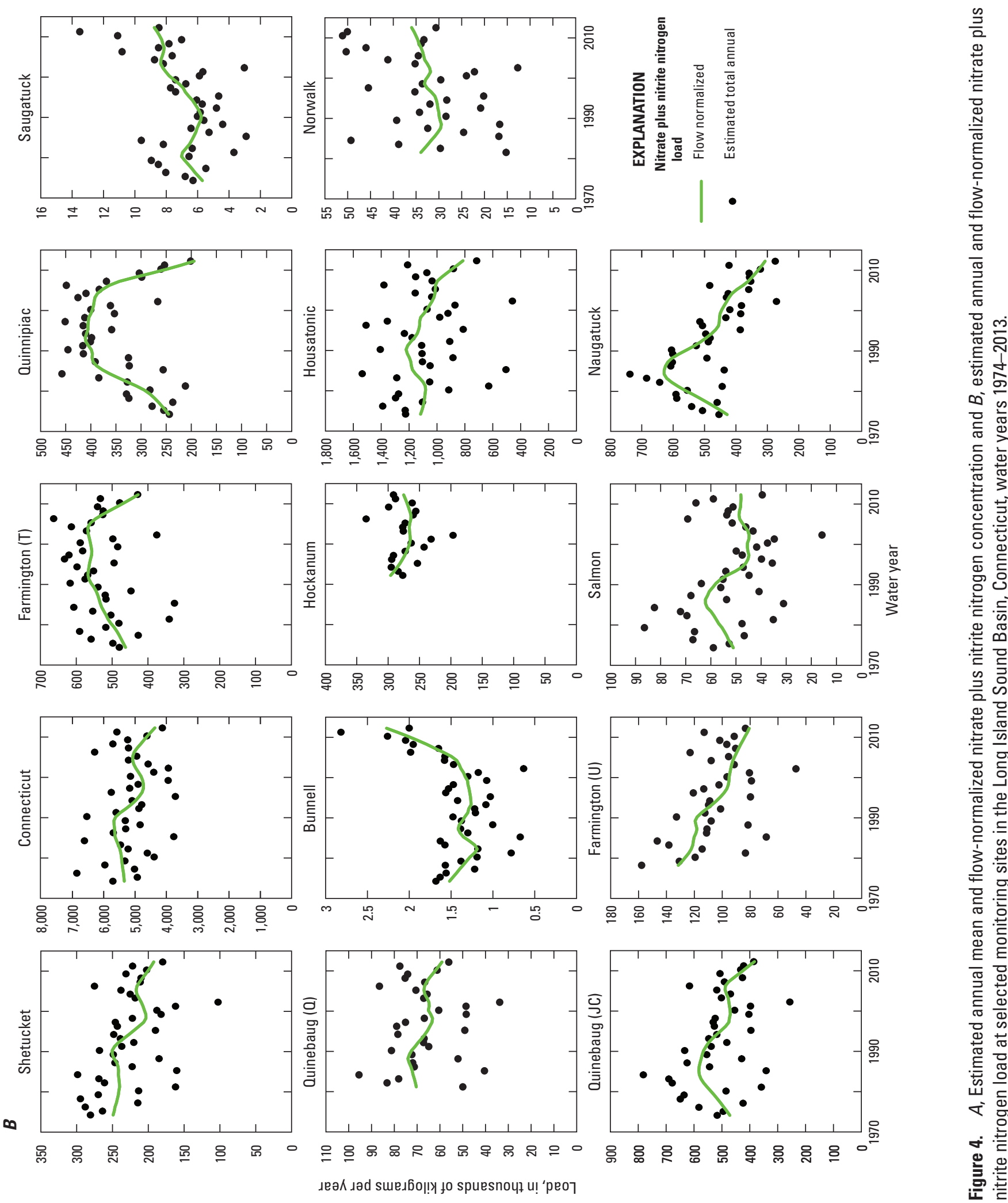
Table 4A. Change in flow-normalized concentration and flow-normalized load of total nitrogen at selected monitoring sites in the Long Island Sound Basin, Connecticut, water years 1974-2013 and 2001-13.

[mg/L, milligrams per liter]

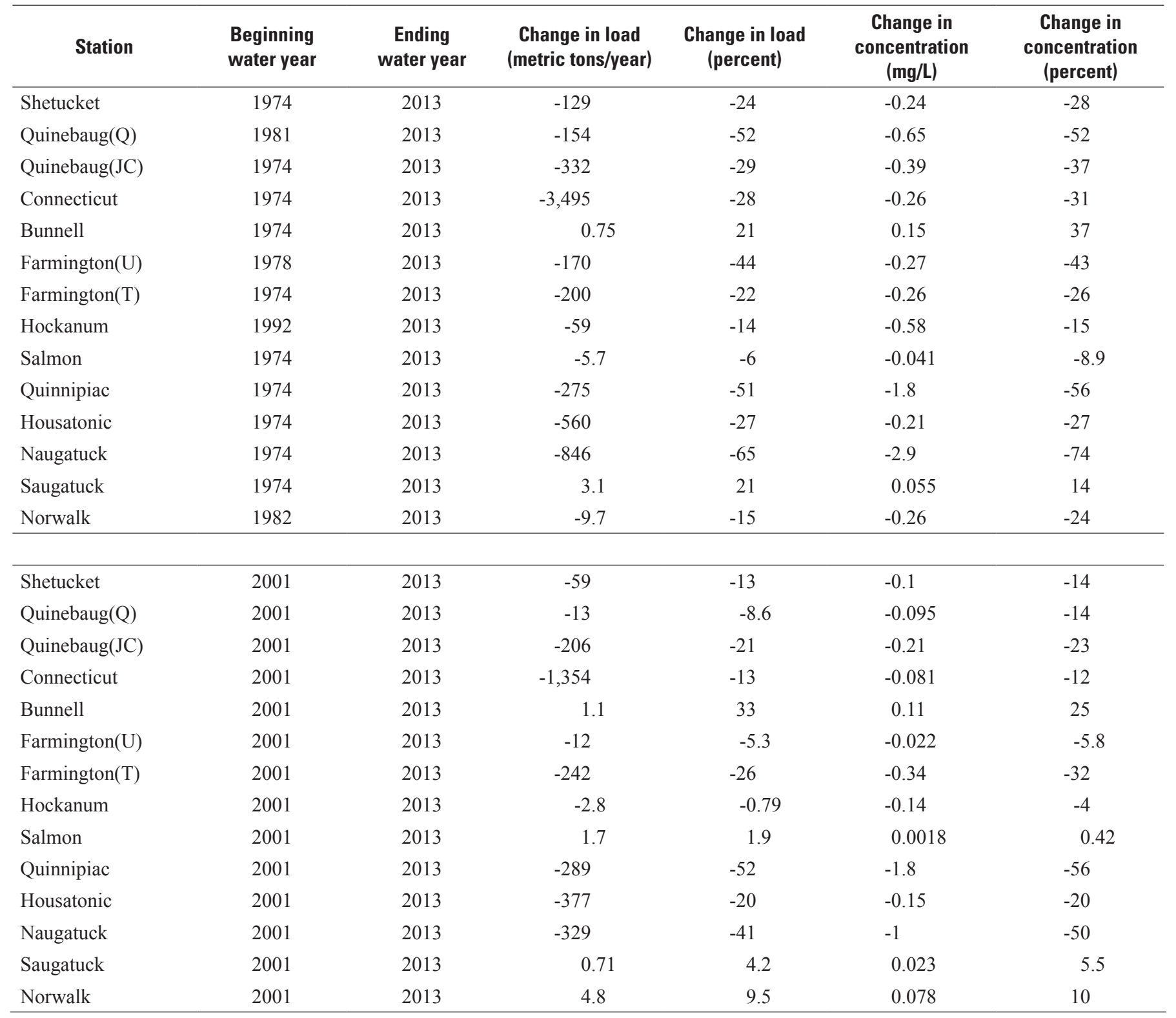


Table 4B. Change in flow-normalized concentration and flow-normalized load of Kjeldahl nitrogen at selected monitoring sites in the Long Island Sound Basin, Connecticut, water years 1974-2013 and 2001-13.

[mg/L, milligrams per liter]

\begin{tabular}{|c|c|c|c|c|c|c|}
\hline Station & $\begin{array}{l}\text { Beginning } \\
\text { water year }\end{array}$ & $\begin{array}{c}\text { Ending } \\
\text { water year }\end{array}$ & $\begin{array}{l}\text { Change in load } \\
\text { (metric tons/year) }\end{array}$ & $\begin{array}{l}\text { Change in load } \\
\text { (percent) }\end{array}$ & $\begin{array}{c}\text { Change in } \\
\text { concentration } \\
(\mathrm{mg} / \mathrm{L})\end{array}$ & $\begin{array}{c}\text { Change in } \\
\text { concentration } \\
\text { (percent) }\end{array}$ \\
\hline Shetucket & 1974 & 2013 & -75 & -26 & -0.14 & -31 \\
\hline Quinebaug(Q) & 1981 & 2013 & -143 & -63 & -0.54 & -63 \\
\hline Quinebaug(JC) & 1974 & 2013 & -224 & -35 & -0.35 & -49 \\
\hline Connecticut & 1974 & 2013 & $-2,284$ & -32 & -0.2 & -41 \\
\hline Bunnell & 1974 & 2013 & -0.23 & -11 & 0.018 & 9 \\
\hline Farmington(U) & 1978 & 2013 & -120 & -47 & -0.16 & -42 \\
\hline Farmington(T) & 1974 & 2013 & -171 & -38 & -0.21 & -43 \\
\hline Hockanum & 1992 & 2013 & -44 & -38 & -0.33 & -34 \\
\hline Salmon & 1974 & 2013 & -14 & -26 & -0.026 & -11 \\
\hline Quinnipiac & 1974 & 2013 & -220 & -68 & -1.4 & -77 \\
\hline Housatonic & 1974 & 2013 & -273 & -27 & -0.088 & -22 \\
\hline Naugatuck & 1974 & 2013 & -741 & -82 & -2.6 & -88 \\
\hline Saugatuck & 1974 & 2013 & 0.17 & 1.9 & 0.014 & 6 \\
\hline Norwalk & 1982 & 2013 & -13 & -39 & -0.26 & -46 \\
\hline Shetucket & 2001 & 2013 & -41 & -16 & -0.07 & -19 \\
\hline Quinebaug(Q) & 2001 & 2013 & -6.5 & -7.3 & -0.048 & -13 \\
\hline Quinebaug(JC) & 2001 & 2013 & -104 & -20 & -0.13 & -26 \\
\hline Connecticut & 2001 & 2013 & -472 & -9 & -0.024 & -7.4 \\
\hline Bunnell & 2001 & 2013 & -0.015 & -0.76 & -0.048 & -18 \\
\hline Farmington(U) & 2001 & 2013 & -0.036 & -0.027 & 0.007 & 3.2 \\
\hline Farmington(T) & 2001 & 2013 & -86 & -23 & -0.097 & -26 \\
\hline Hockanum & 2001 & 2013 & -17 & -19 & -0.14 & -19 \\
\hline Salmon & 2001 & 2013 & -7.2 & -16 & -0.016 & -6.9 \\
\hline Quinnipiac & 2001 & 2013 & -63 & -38 & -0.26 & -38 \\
\hline Housatonic & 2001 & 2013 & -117 & -14 & -0.031 & -9.3 \\
\hline Naugatuck & 2001 & 2013 & -183 & -53 & -0.53 & -61 \\
\hline Saugatuck & 2001 & 2013 & -0.64 & -6.4 & -0.0026 & -1 \\
\hline Norwalk & 2001 & 2013 & -0.46 & -2.3 & -0.0058 & -1.9 \\
\hline
\end{tabular}


Table 4C. Change in flow-normalized concentration and flow-normalized load of nitrate plus nitrite nitrogen at selected monitoring sites in the Long Island Sound Basin, Connecticut, water years 1974-2013 and 2001-13.

[mg/L, milligrams per liter]

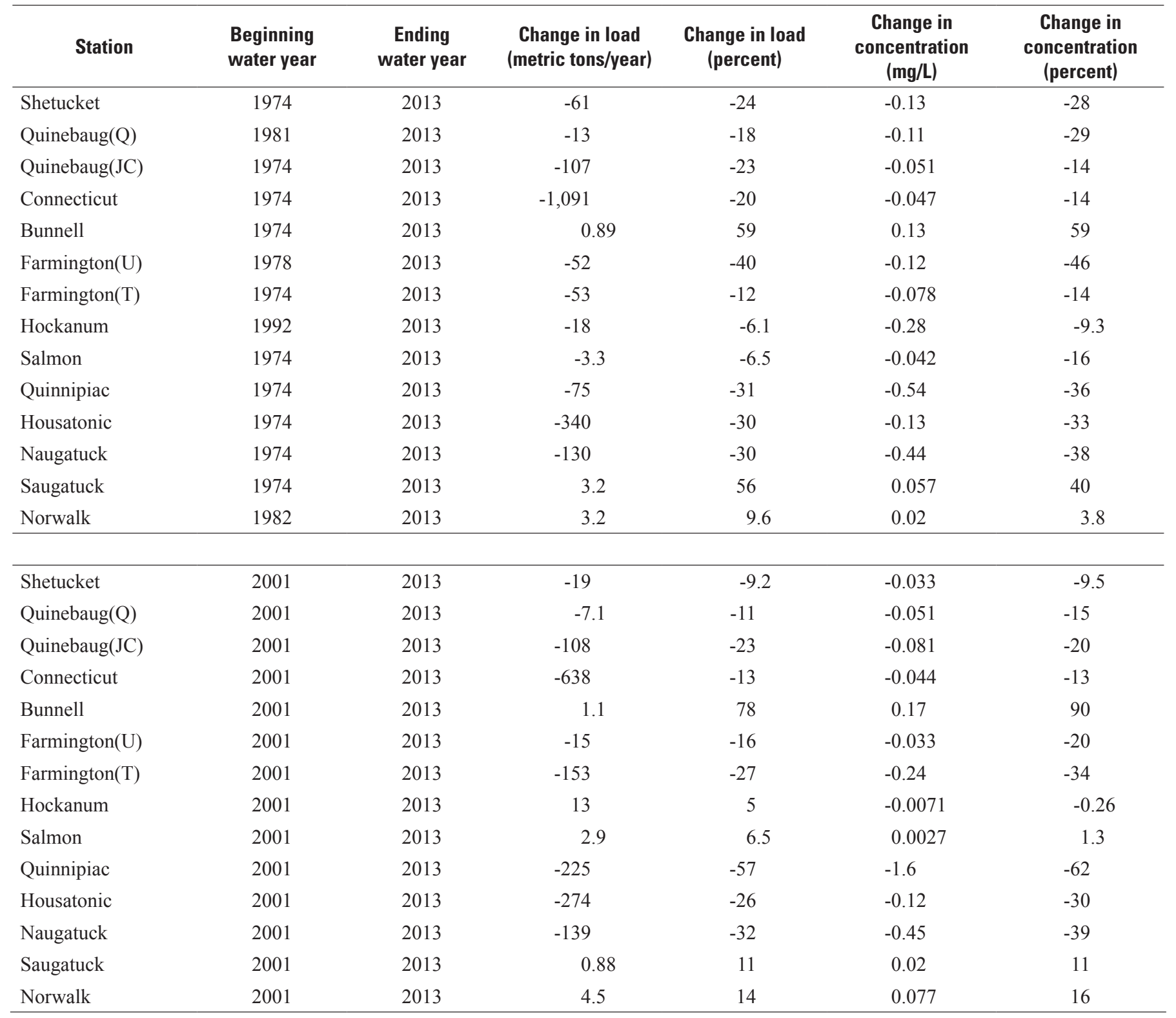


Wet deposition of inorganic nitrogen was summarized from the series of annual gridded map layers published by the National Acid Deposition Program during 1985-2013 (National Atmospheric Deposition Program, 2013) for the basins in this study. Estimates of inorganic nitrogen for 1981-84 are included in figure 5A, using information from Gronberg and others (2014).

During the study period, mean atmospheric wet deposition of inorganic nitrogen across the LIS Basin decreased from about 5.5 to 3.5 kilograms per hectare (fig. $5 \mathrm{~A}$ ). The changes in wet deposition were primarily owing to the decrease in $\mathrm{NO}_{3}^{-}$. Wet deposition of ammonium $\left(\mathrm{NH}_{4}^{+}\right)$remained stable from 1985 to 2013 (fig. 5B). These trends are consistent with reductions in the $\mathrm{NO}_{\mathrm{x}}$ emissions in the northeastern United States, reported by the U.S. Environmental Protection Agency (EPA), as a result of changes under Title IV of the 1990 Clean Air Act Amendments (U.S. Environmental Protection Agency, 2013) and are consistent with other studies in the northeast (Pinder and others, 2011; Butler and others, 2010).

The interplay of many factors related to land-use changes, atmospheric deposition, and WWTF upgrades affects trends in TN seen in this study. In basins with low-density development and some nitrogen from wastewater (table 1; Shetucket, Farmington (T)), wet deposition of inorganic nitrogen was estimated to be of a magnitude similar to that of flow-normalized and non-flow-normalized TN loads at the monitoring sites (fig. 6). In basins affected by large wastewater discharges (Quinnipiac, Naugatuck), estimated wet deposition of inorganic nitrogen was less than the flow-normalized and non-flow-normalized TN loads at the monitoring sites. This is likely due to decreases in wastewater TN as loads in the rivers approach the rates of atmospheric wet deposition (fig. 6).

In basins with low density development and no municipal wastewater discharges (Saugatuck, Bunnell, Salmon), wet deposition of inorganic nitrogen typically has been greater than the loads of TN. In the recent part of the record, however, they are very similar (fig. 6). These relatively undeveloped subbasins also had small increases in the flow-normalized loads of TN and $\mathrm{NO}_{\mathrm{x}}$ (tables 4A, C) from 2001 to 2013.

A possible cause for these small increases may be change in the land use and land cover in many of the basins studied (table 5). Developed land increased an average of 4.5 percent from 1985 to 2010 (for the sum of developed land and turf and grass) at the Saugatuck, Bunnell, and Salmon monitoring sites. Sources of increased N with increased development can include septic systems and fertilizers and are coupled with the loss of $\mathrm{N}$ sinks, such as wetlands and forests.

This land-use change also occurred in many of the study basins that receive wastewater and possibly increased nonpoint source loading of $\mathrm{N}$. The increases may not be apparent because they are much smaller than the reductions from improving wastewater discharge and decreases in wet deposition of inorganic N. Currently (2013), information is lacking on whether nonpoint loads of $\mathrm{N}$ in some of the smaller coastal streams and embayments of LIS are declining because there is a lack of long-term data for trend analyses in these areas.
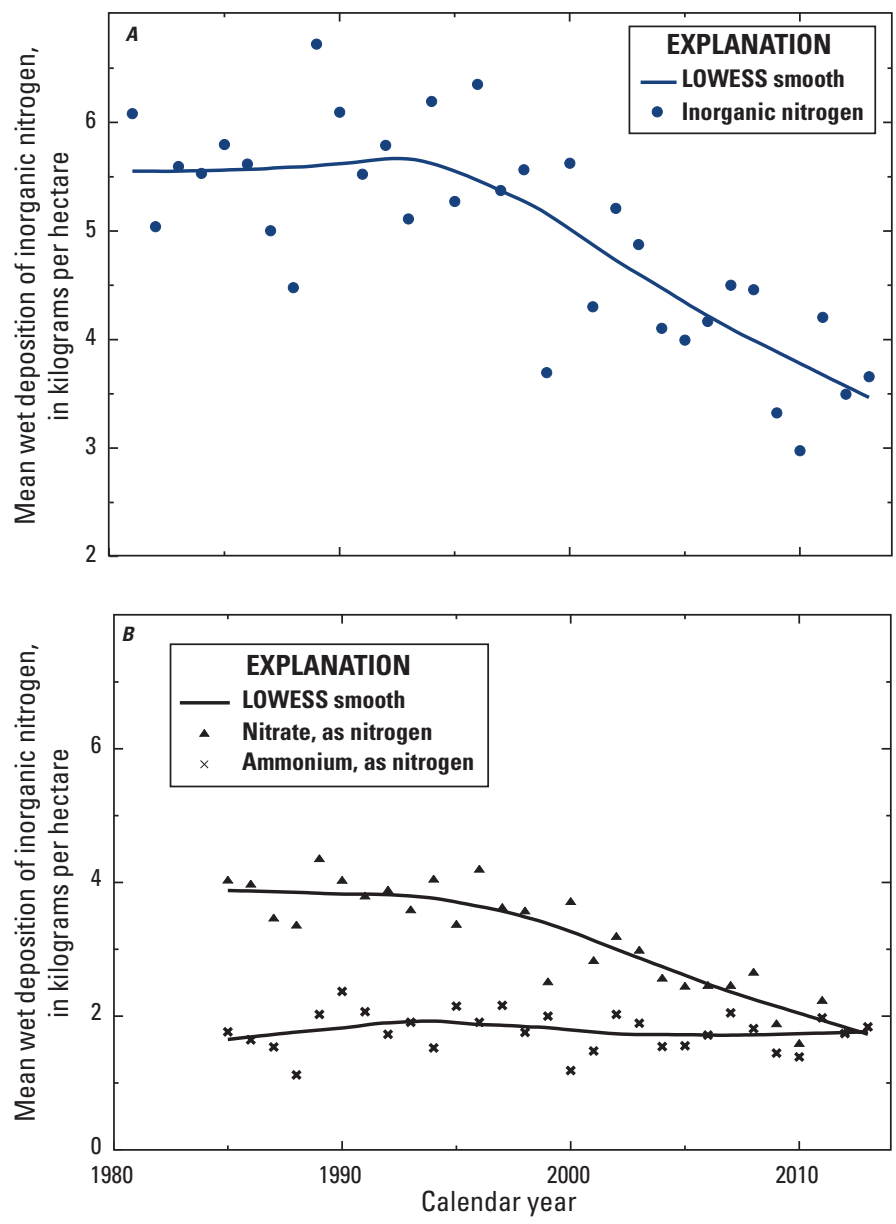

Figure 5. Mean wet deposition of $A$, inorganic nitrogen during 1981-2013 and $B$, nitrate and ammonium during 1985-2013 for the Long Island Sound Basin. Trend lines on both plots are locally weighted scatterplot smoothed (LOWESS; Cleveland, 1979).

Caution is needed when interpreting the causes of trends at sites that are largely forested because other factors, such as climate change, forest history, and particularly soil temperatures and changing paths of soil water flow, may affect the TN loads in forested areas over time, such as described by Bernal and others (2012).

\section{Total Phosphorus}

Total phosphorus (including flow-normalized and nonflow-normalized) concentrations at monitoring sites in this study have decreased during water years 1974-2013 and 2001-13 with a couple of exceptions (fig. 7; table 6). The flow-normalized loads of TP also decreased at most of the sites studied for these periods. Non-flow-normalized loads generally decreased at most stations; however, some high-flow events or high-flow years have led to large loads, for example 

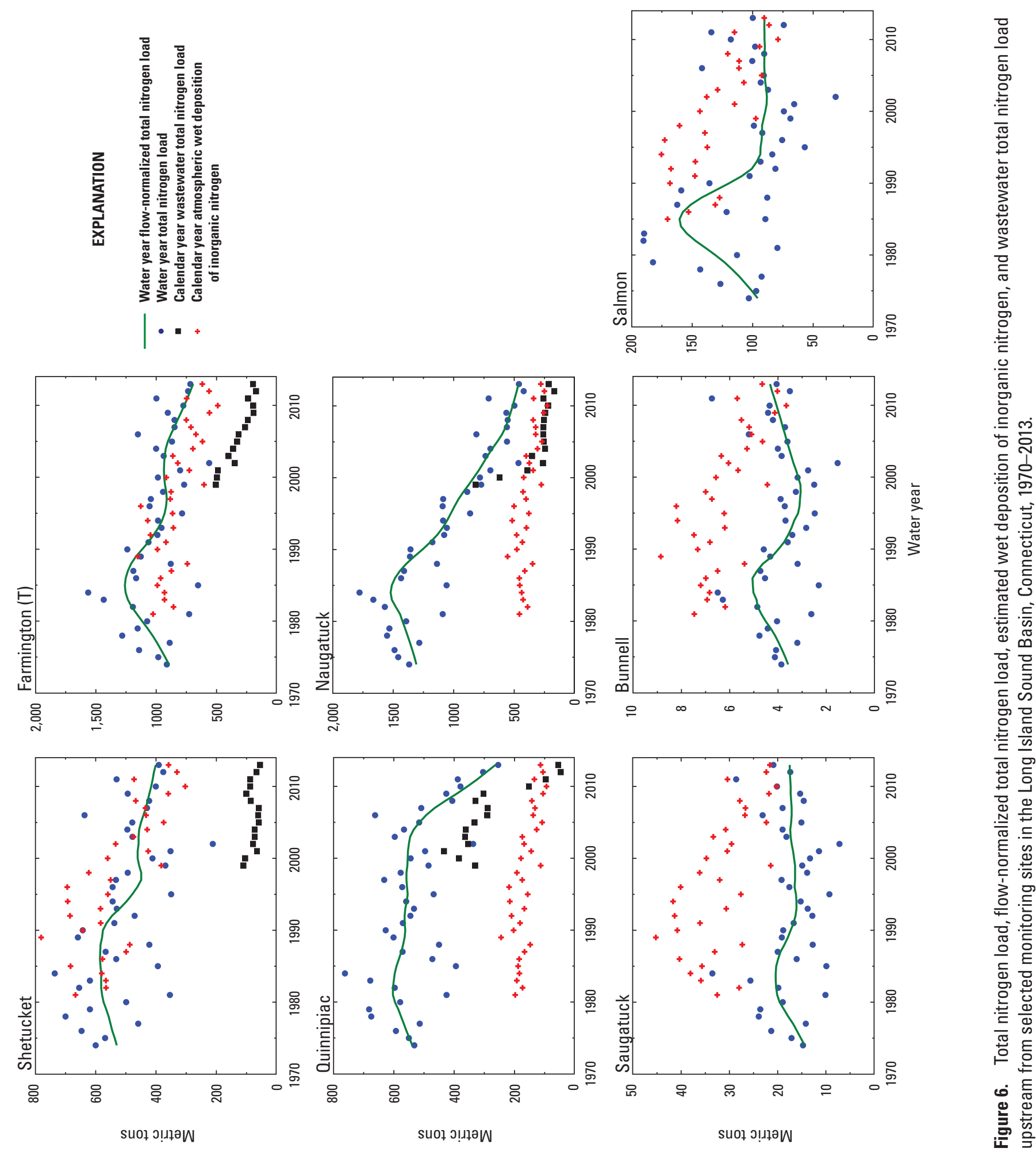
Table 5. Land use, land cover, and land-use change in basins of selected monitoring sites in the Long Island Sound Basin, 1985-2010.

[Values in percent of upstream basin area]

\begin{tabular}{|c|c|c|c|c|c|c|c|c|c|c|}
\hline $\begin{array}{l}\text { Monitoring } \\
\text { site }\end{array}$ & $\begin{array}{c}\text { Developed } \\
\text { before } \\
1985\end{array}$ & $\begin{array}{c}\text { Turf and } \\
\text { grass } \\
\text { before } \\
1985\end{array}$ & $\begin{array}{l}\text { Unde- } \\
\text { veloped }\end{array}$ & $\begin{array}{c}\text { Changed } \\
\text { to } \\
\text { developed } \\
\text { (2010) }\end{array}$ & $\begin{array}{c}\text { Changed } \\
\text { to } \\
\text { turf and } \\
\text { grass } \\
(2010)\end{array}$ & $\begin{array}{c}\text { Changed }^{1} \\
\text { from agri- } \\
\text { cultural field } \\
\text { to developed } \\
\text { or turf and } \\
\text { grass }\end{array}$ & $\begin{array}{l}\text { Changed }^{1} \\
\text { from } \\
\text { forest to } \\
\text { developed } \\
\text { or turf and } \\
\text { grass }\end{array}$ & $\begin{array}{c}\text { Estimated }^{2} \\
\text { impervi- } \\
\text { ous area } \\
\text { in } 1985\end{array}$ & $\begin{array}{l}\text { Estimated }^{2} \\
\text { impervi- } \\
\text { ous area } \\
\text { in } 2010\end{array}$ & $\begin{array}{c}\text { Waste- } \\
\text { water } \\
\text { influ- } \\
\text { ence }\end{array}$ \\
\hline Shetucket & 8.7 & 2.6 & 82.2 & 2 & 1.5 & 0.5 & 2.7 & 3.7 & 4.3 & Minor \\
\hline Hockanum & 25.7 & 8.8 & 54.8 & 5.9 & 2.6 & 2.9 & 4.5 & 10.5 & 12.1 & Major \\
\hline Salmon & 11 & 3.3 & 78.7 & 2.5 & 2.5 & 1.2 & 3.3 & 4.6 & 5.3 & \\
\hline Quinnipiac & 28.1 & 12.6 & 49.8 & 5.4 & 2.2 & 1.4 & 4.9 & 11.5 & 13.0 & Major \\
\hline Naugatuck & 17.9 & 5.6 & 68.9 & 3.4 & 1.5 & 0.8 & 3.7 & 7.5 & 8.4 & Major \\
\hline
\end{tabular}

${ }^{1}$ Land use/land cover change information from University of Connecticut Center for Land Use Education and Research (undated a).

${ }^{2}$ Impervious area estimated using methods from University of Connecticut Center for Land Use Education and Research (undated b).

water years 2006 and 2011 with high annual streamflows. In water years 2006 and 2011, streamflows in Connecticut ranked in the 98.3 and 94.8 percentiles, respectively, during 1901-2014 (U.S. Geological Survey, undated). In water year 2011, the Connecticut site had the largest estimated loads of TP for the entire period of record, likely owing to high streamflow, particularly from Tropical Storms Irene and Lee; major flooding occurred at the headwaters in Vermont (Flynn, 2014), which mobilized large volumes of sediment.

Average flow-normalized load of TP decreased 46.9 percent during water years 1974-2013 and decreased 13 percent during water years 2001-13. Decreases in flow-normalized concentrations averaged 52.7 percent and 15.1 percent for water years 1974-2013 and 2001-13, respectively (table 6). The only monitoring site with an increase ( 7.1 percent) in flow-normalized concentration over the entire study period (1974-2013) was the Naugatuck River, which had a decrease in load during the same period. The flow-normalized concentrations of TP during water years 2001-13 increased by 8.5, 14, and 2.9 percent at Farmington (U), Naugatuck, and Saugatuck sites, respectively (table 6). There were increases in flow-normalized loads of TP (water years 2001-13) at 4 sites (Connecticut, Farmington (U), Naugatuck, and Saugatuck) and increases in flow-normalized concentrations of TP at 3 sites (Farmington (U), Naugatuck, and Saugatuck; table 6). These increases in flow-normalized concentrations and loads are small in magnitude and may be better analyzed using a bootstrap test, which is under development for WRTDS (Robert Hirsch, U.S. Geological Survey, written commun., April 2015).
Although flow-normalized concentrations of TP at the Connecticut monitoring site during water years 2001-13 were generally decreasing, the flow-normalized load increased slightly (table 6). An analysis of a contour plot of the differences in expected concentrations in relation to streamflow over time shows a pattern of decreased concentrations of TP at low and moderate streamflows (an indication of reduction of TP from WWTFs) and increases in concentrations of TP at high streamflows (an indication of nonpoint source discharges; fig. 8).

The decreases in TP concentrations and loads have been attributed to improvements in wastewater treatment, including the change to secondary wastewater treatment at facilities in Connecticut, and the removal of phosphorus from laundry detergents during 1972-95 in states containing the LIS Basin (Litke, 1999; Trench and others, 2012). Other possible factors for decreases in TP include the conversion of agricultural land to low density developed land (table 5), the implementation of agricultural and urban best management practices, and phosphorus removal at some wastewater facilities.

CTDEEP is currently (2013) in the process of implementing lower limits for TP in effluents from WWTFs upstream from study sites in this investigation. Current and future permits for individual facilities (implemented from 2013 to 2022) may be limited by daily load or by concentrations ranging from 0.1 to $2.5 \mathrm{mg} / \mathrm{L}$ (Rowland Denny, CTDEEP, written commun., February 2015).

Decreases in flow-normalized TP concentrations and loads at sites without WWTF discharges, such as Saugatuck, Bunnell, and Salmon, in the early part of the record may be due to limits on phosphorus in laundry detergents. Changes to 

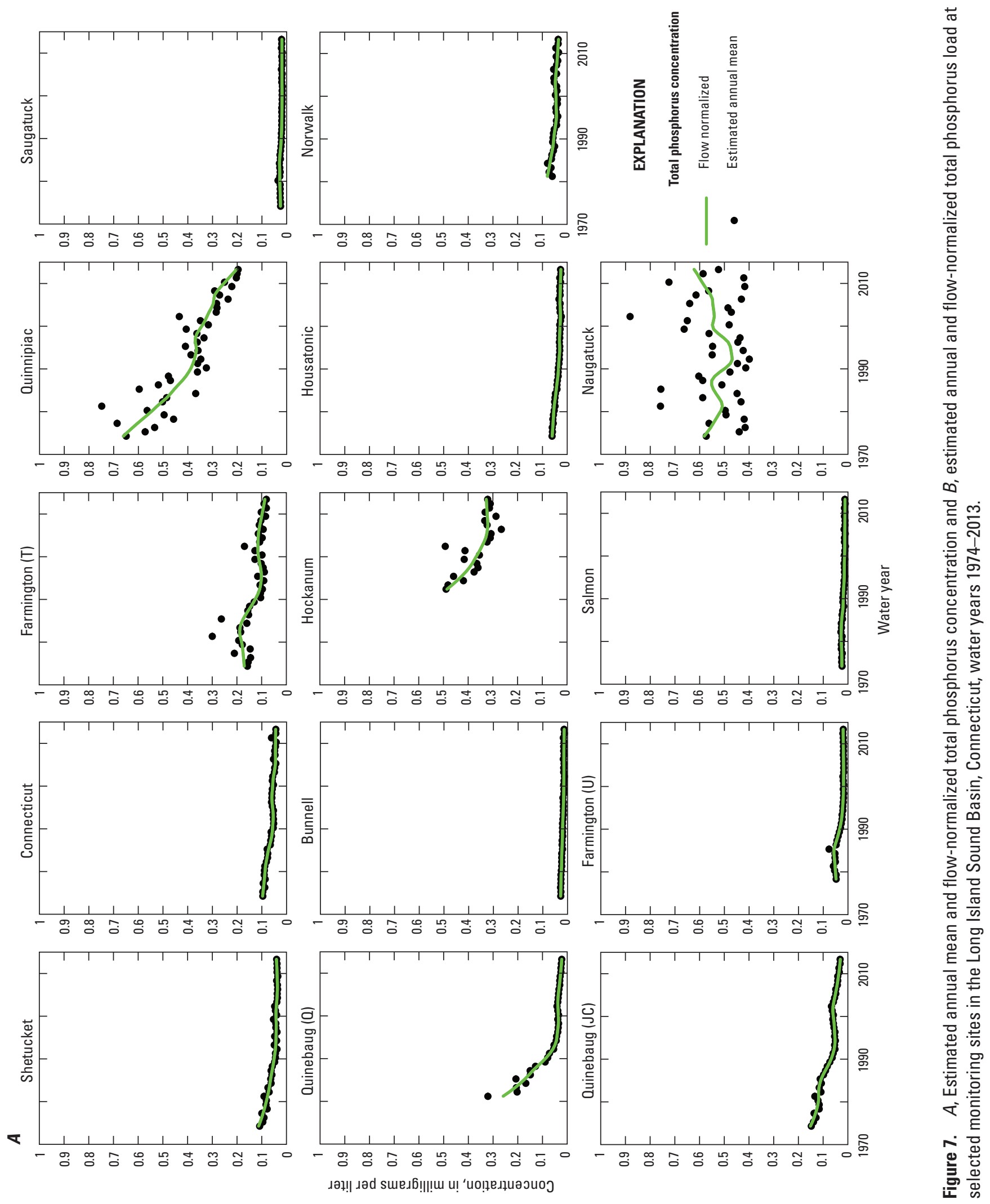

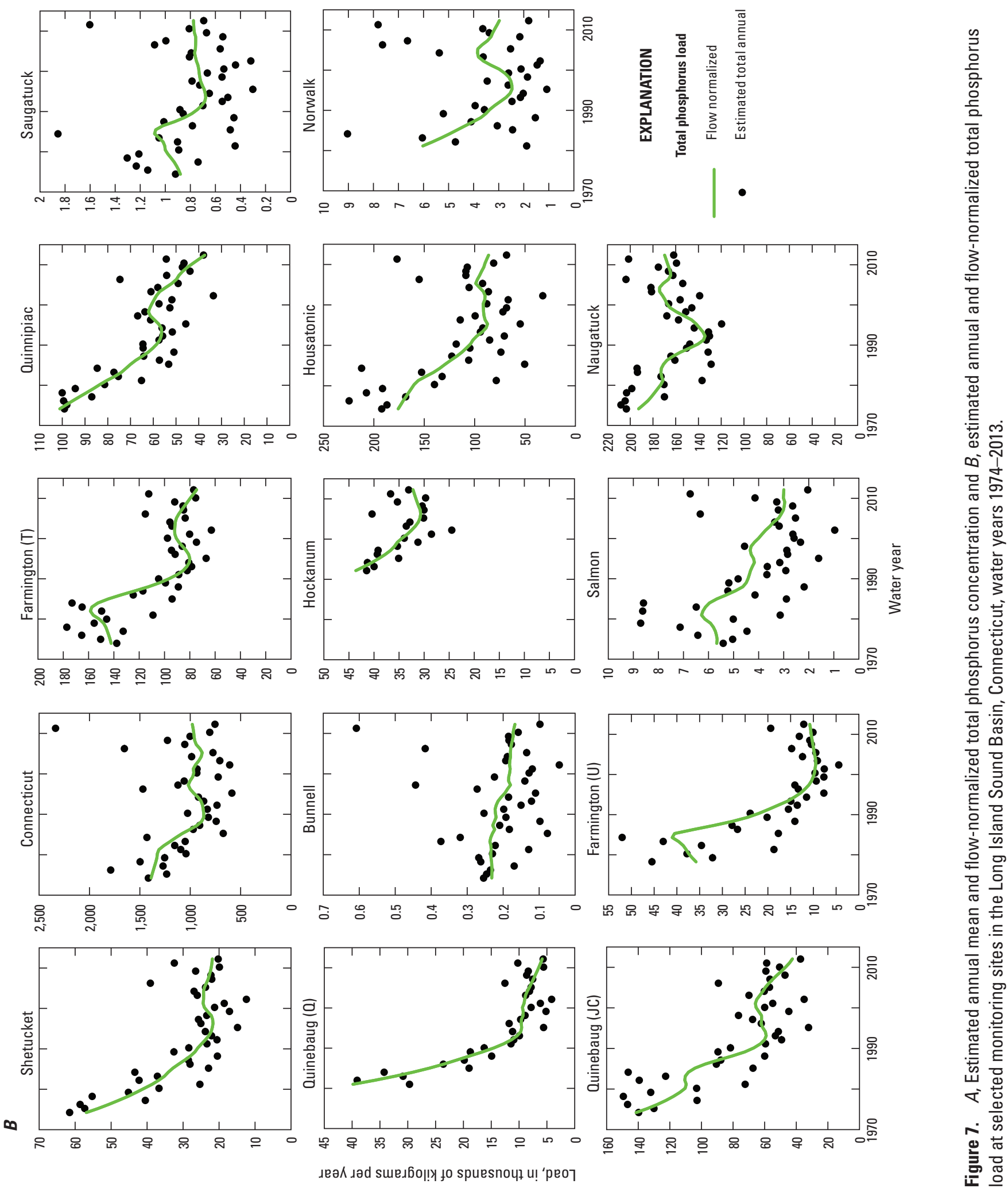
Table 6. Change in flow-normalized concentrations and flow-normalized loads of total phosphorus at selected monitoring sites in the Long Island Sound Basin, Connecticut, water years 1974-2013 and water years 2001-13.

[mg/L, milligrams per liter]

\begin{tabular}{|c|c|c|c|c|c|c|}
\hline Station & $\begin{array}{l}\text { Beginning } \\
\text { water year }\end{array}$ & $\begin{array}{c}\text { Ending } \\
\text { water year }\end{array}$ & $\begin{array}{l}\text { Change in load } \\
\text { (metric tons/year) }\end{array}$ & $\begin{array}{c}\text { Change in load } \\
\text { (percent) }\end{array}$ & $\begin{array}{l}\text { Change in } \\
\text { concentration } \\
\text { (mg/L) }\end{array}$ & $\begin{array}{l}\text { Change in } \\
\text { concentration } \\
\text { (percent) }\end{array}$ \\
\hline Shetucket & 1974 & 2013 & -35 & -62 & -0.072 & -64 \\
\hline Quinebaug(Q) & 1981 & 2013 & -34 & -86 & -0.24 & -92 \\
\hline Quinebaug(JC) & 1974 & 2013 & -101 & -71 & -0.12 & -80 \\
\hline Connecticut & 1974 & 2013 & -398 & -29 & -0.053 & -55 \\
\hline Bunnell & 1974 & 2013 & -0.067 & -29 & -0.014 & -54 \\
\hline Farmington(U) & 1978 & 2013 & -25 & -69 & -0.029 & -60 \\
\hline Farmington(T) & 1974 & 2013 & -70 & -49 & -0.083 & -49 \\
\hline Hockanum & 1992 & 2013 & -11 & -26 & -0.16 & -33 \\
\hline Salmon & 1974 & 2013 & -2.7 & -47 & -0.013 & -53 \\
\hline Quinnipiac & 1974 & 2013 & -66 & -65 & -0.46 & -69 \\
\hline Housatonic & 1974 & 2013 & -91 & -52 & -0.035 & -58 \\
\hline Naugatuck & 1974 & 2013 & -21 & -11 & 0.041 & 7.1 \\
\hline Saugatuck & 1974 & 2013 & -0.1 & -12 & -0.0058 & -24 \\
\hline Norwalk & 1982 & 2013 & -2.7 & -48 & -0.042 & -54 \\
\hline Shetucket & 2001 & 2013 & -2.6 & -11 & -0.0017 & -4 \\
\hline Quinebaug(Q) & 2001 & 2013 & -3.5 & -38 & -0.015 & -40 \\
\hline Quinebaug(JC) & 2001 & 2013 & -26 & -39 & -0.031 & -50 \\
\hline Connecticut & 2001 & 2013 & 21 & 2.1 & -0.011 & -20 \\
\hline Bunnell & 2001 & 2013 & -0.016 & -8.7 & -0.0012 & -9.1 \\
\hline Farmington(U) & 2001 & 2013 & 1.3 & 13 & 0.0015 & 8.5 \\
\hline Farmington(T) & 2001 & 2013 & -20 & -21 & -0.028 & -25 \\
\hline Hockanum & 2001 & 2013 & -0.92 & -2.7 & -0.027 & -7.6 \\
\hline Salmon & 2001 & 2013 & -0.88 & -23 & -0.0012 & -9.5 \\
\hline Quinnipiac & 2001 & 2013 & -25 & -41 & -0.13 & -39 \\
\hline Housatonic & 2001 & 2013 & -5.6 & -6.2 & -0.0022 & -7.9 \\
\hline Naugatuck & 2001 & 2013 & 1.8 & 1 & 0.079 & 14 \\
\hline Saugatuck & 2001 & 2013 & 0.037 & 5.1 & 0.00052 & 2.9 \\
\hline Norwalk & 2001 & 2013 & -0.41 & -12 & -0.011 & -24 \\
\hline
\end{tabular}

land use in these basins from 1985 to 2010 were dominated by loss of forest and farmland, and increases in developed land (table 5).

\section{Total Organic Carbon}

Flow-normalized concentrations and loads of TOC decreased at nearly all 14 sites during water years 1974-2013 and 2001-13 (fig. 9; table 7). Decreases in flow-normalized loads averaged 28.7 percent for the full period of the study and 11.7 percent for water years 2001-13. At many of the sites, the greatest decreases in flow-normalized concentrations occurred prior to 1990 with annual values stabilizing toward the later part of the record. Although the flow-normalized loads decreased, the annual estimated unadjusted loads of TOC were large during high-flow water years 2006 and 2011, like other constituents.

Decreases in flow-normalized TOC concentrations and loads (parallel with TP decreases in the early part of the record) at sites receiving wastewater are likely partly attributable to improvements in wastewater practices. Sites with no wastewater discharges (Saugatuck, Bunnell, and Salmon) also had decreases in flow-normalized TOC concentrations and loads, indicating that there were changes in other sources of 


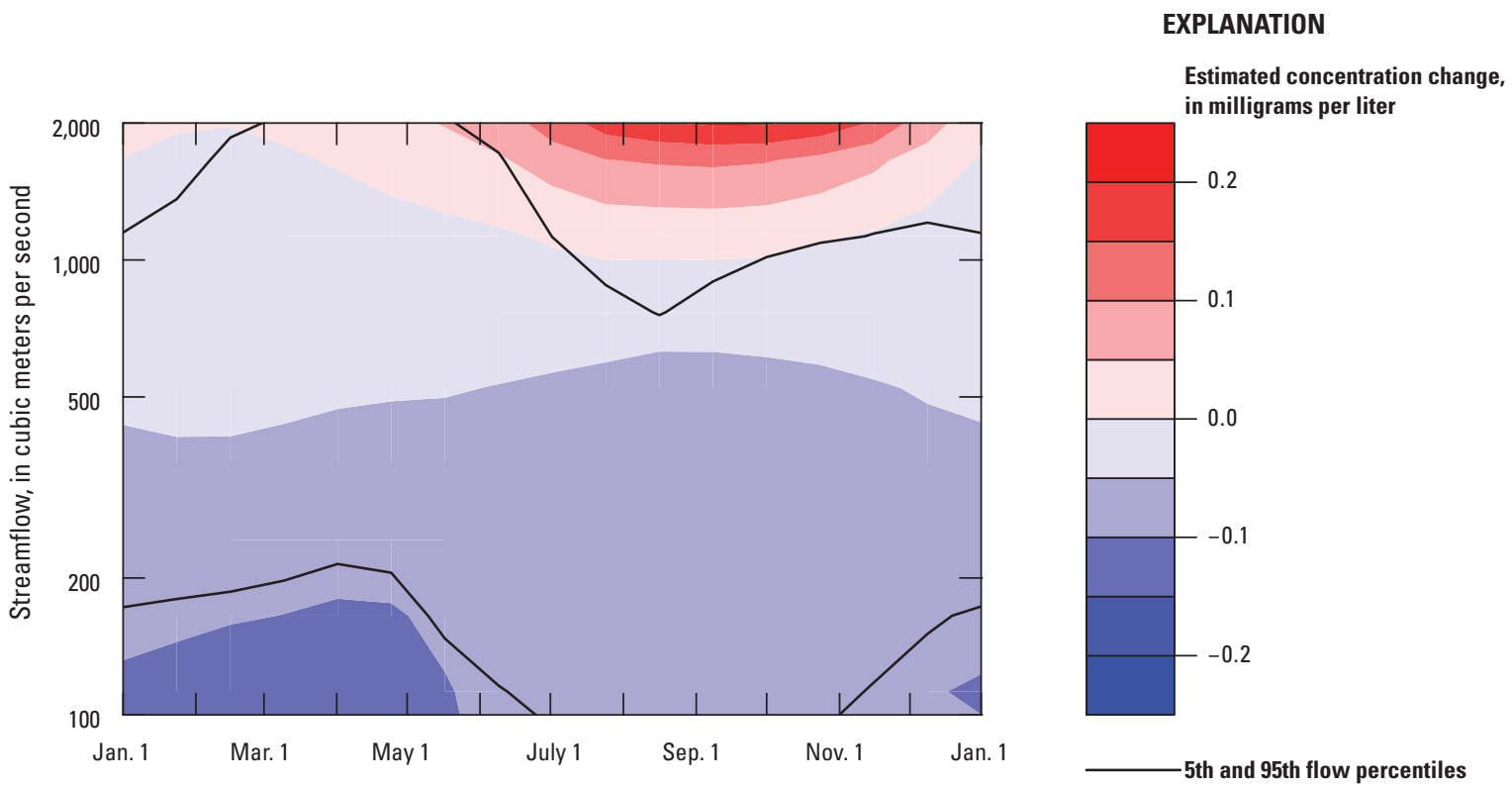

Figure 8. Change in expected flow-adjusted total phosphorus concentrations in relation to streamflow by time of year, in the Connecticut River at Thompsonville monitoring site, in the Long Island Sound Basin, Connecticut, water years 1974-2013.

TOC. Some of the changes to dissolved organic carbon (DOC) concentrations and loads can be attributed to human activity, such as loss of agricultural land, changes in agricultural practices, loss of forest cover and wetlands, changes to the basin hydrology owing to development, and climate changes (Stanley and others, 2012).

\section{Silica}

Flow-normalized concentrations and loads of DSi (as silicon dioxide $\left[\mathrm{SiO}_{2}\right]$ ) increased slightly at most of the 14 sites during both periods (fig. 10; table 8 ). The average increase in flow-normalized load was 8.5 percent from water year 1974 to 2013 and 2.7 percent from water year 2001 to 2013. The average increase in flow-normalized concentration of DSi was 3.8 percent from water year 1974 to 2013 and 2.3 percent from water year 2001 to 2013. Sites with decreases in flow-normalized load over the entire study period include the Hockanum, Naugatuck, and Norwalk, and sites with decreases for water years 2001-13 are the Naugatuck and Norwalk. Increases in flow-normalized loads and concentrations were largest for both periods at the Housatonic site. This site is located downstream from Lake Zoar, a large impoundment. Initial DSi concentrations (water year 1974) were the lowest at the Housatonic site, indicating possible effects of this or other upstream impoundments as a traps for biogenic Si incorporated into diatoms. Decreases in TP loads at this site could be related to increases in the loads of $\mathrm{DSi}$, similar to that reported by Hartmann and others (2011 for the Rhine River, which had increasing loads of DSi with declining loads of phosphate and $\mathrm{NO}_{3}^{-}$.

The slightly increasing flow-normalized concentrations and loads of DSi may be affected by declining TP concentrations in some of the basins upstream from the monitoring sites, limiting productivity of diatoms. Observed increases in summer base flows (Hodgkins and Dudley, 2011) may be related to increasing DSi loads from groundwater.

Increases in flow-normalized DSi concentrations and loads also may have been affected by increased urbanization during the study period. Differences in DSi yields (load divided by drainage area) among sites were compared by their land-use characteristics. Median yields of DSi from water year 2001 through 2013 were evaluated using a multiple linearregression (MLR) model (table 9) with the land-use categories in table 1 as the independent variables. Results of the evaluation indicate that the strongest predictors of median DSi yields are area of open water in the basin and area of developed land, a finding similar to that of other work in the LIS Basin (Carey and Fulweiler, 2011). The percent of open water in the basin had a negative relation with DSi loads (fig. 11), whereas developed land had a positive relation with DSi loads. Carey and Fulweiler (2011) hypothesize that increasing development and land-use change inhibits plant uptake of $\mathrm{Si}$, and increased wastewater discharges increase Si load. A contrasting effect from increased impervious cover associated with urbanization is a decrease in groundwater discharge relative to stormwater runoff, which may result in reduced load of DSi (Loucaides and others, 2007). 

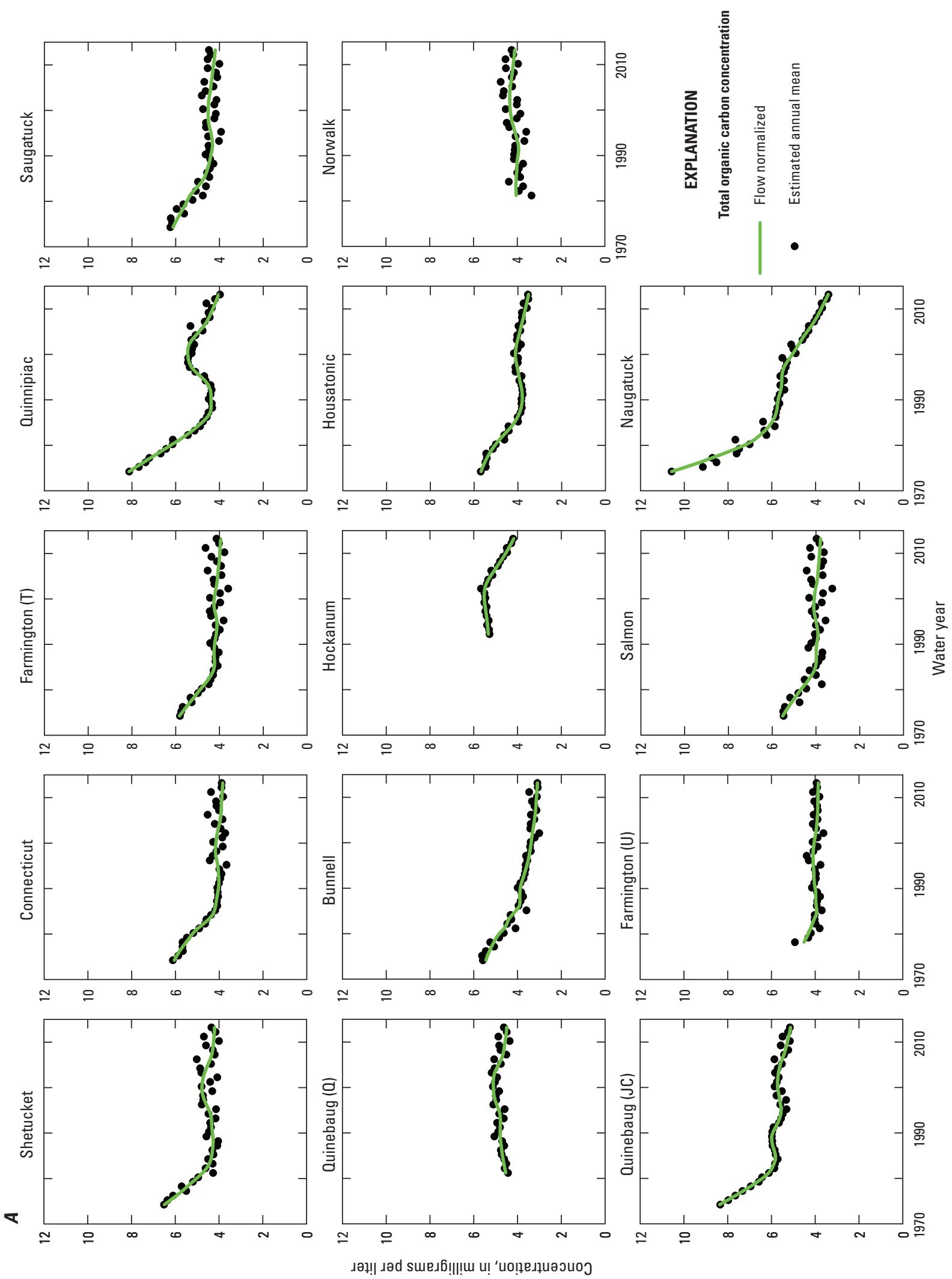

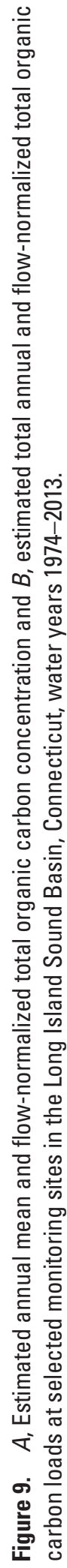



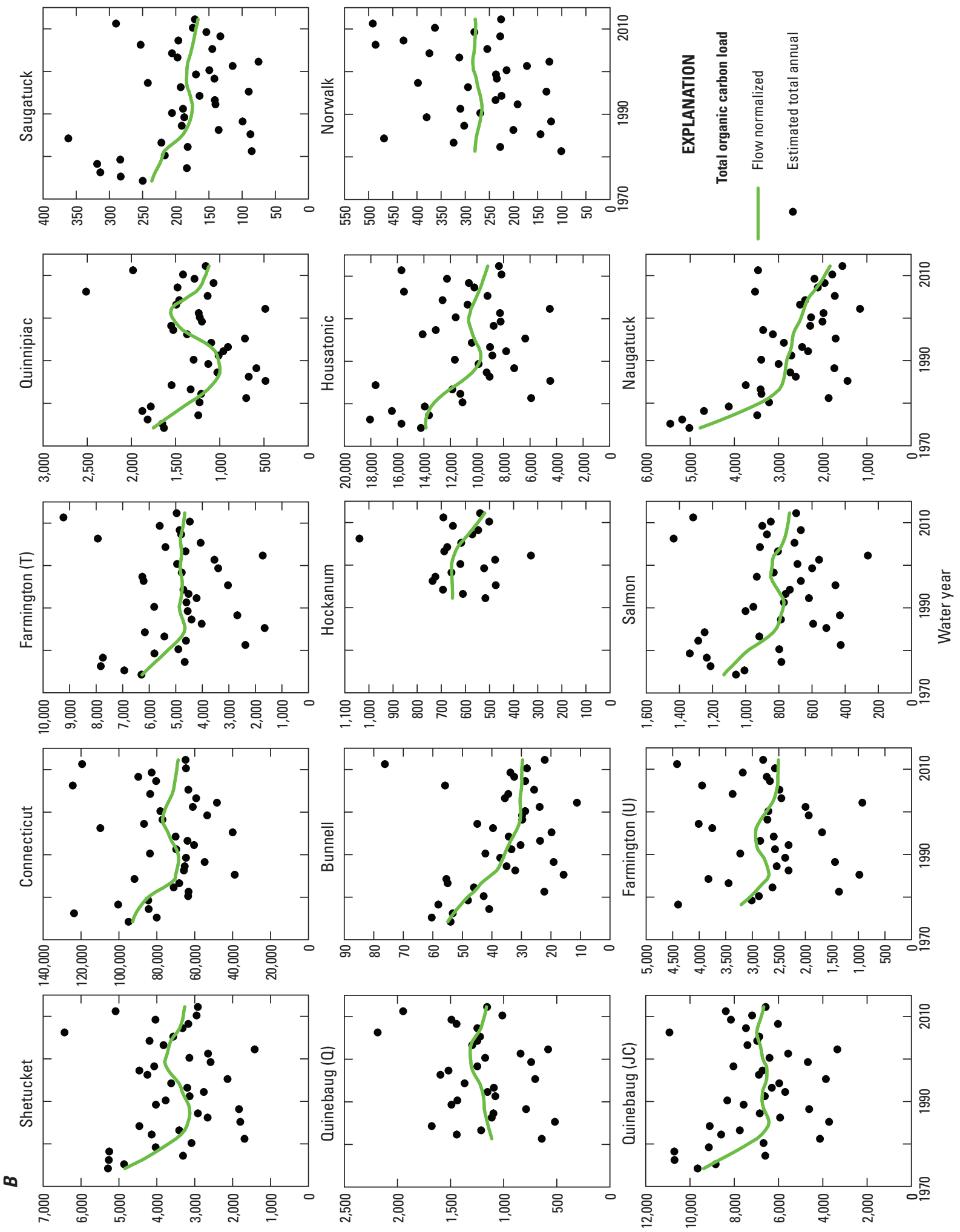

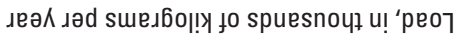

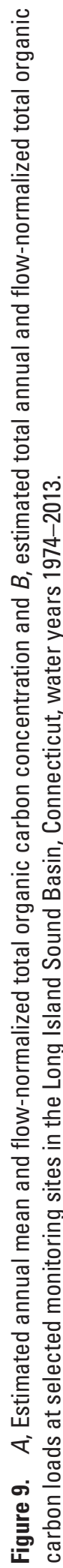


Table 7. Change in flow-normalized concentrations and flow-normalized loads of total organic carbon at selected monitoring sites in the Long Island Sound Basin, Connecticut, water years 1974-2013 and water years 2001-13.

[mg/L, milligrams per liter]

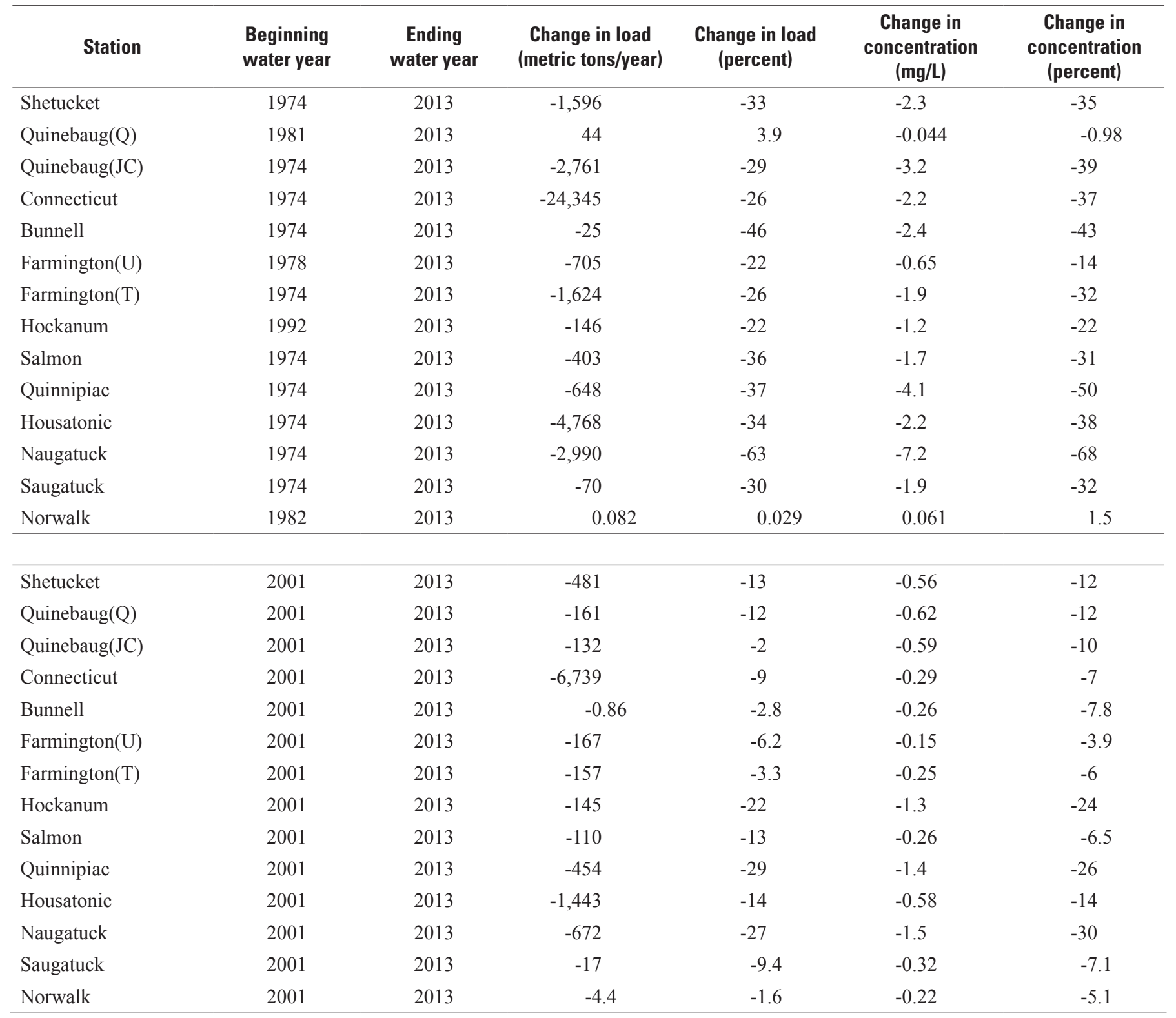



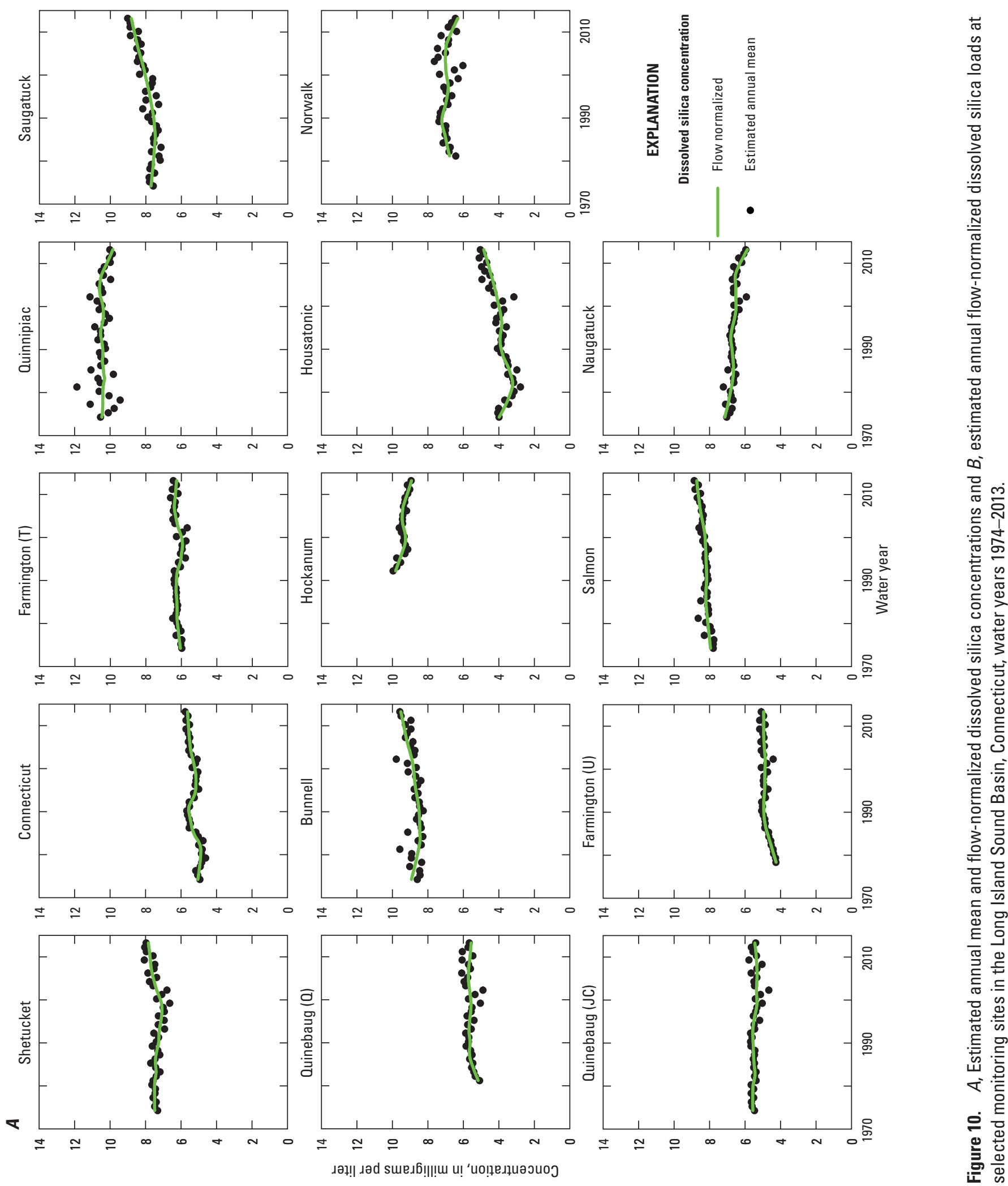


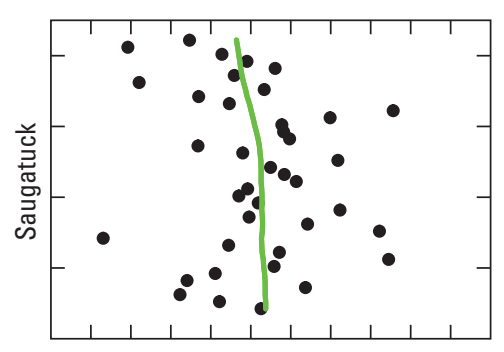

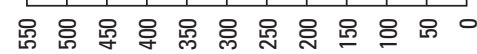
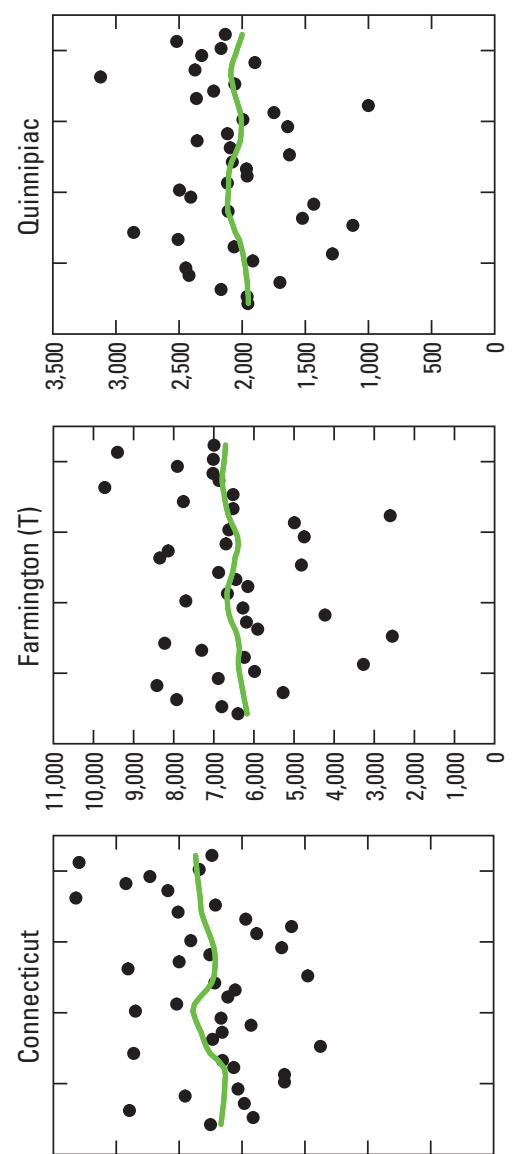

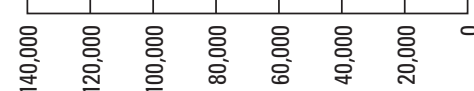

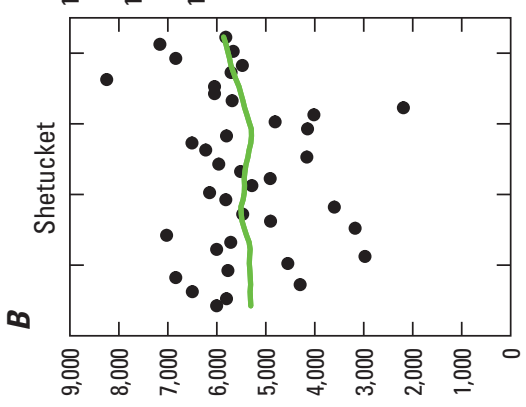

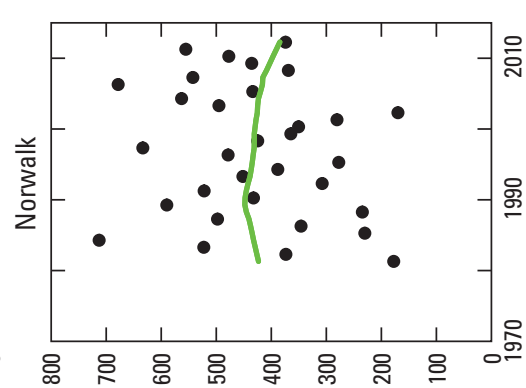
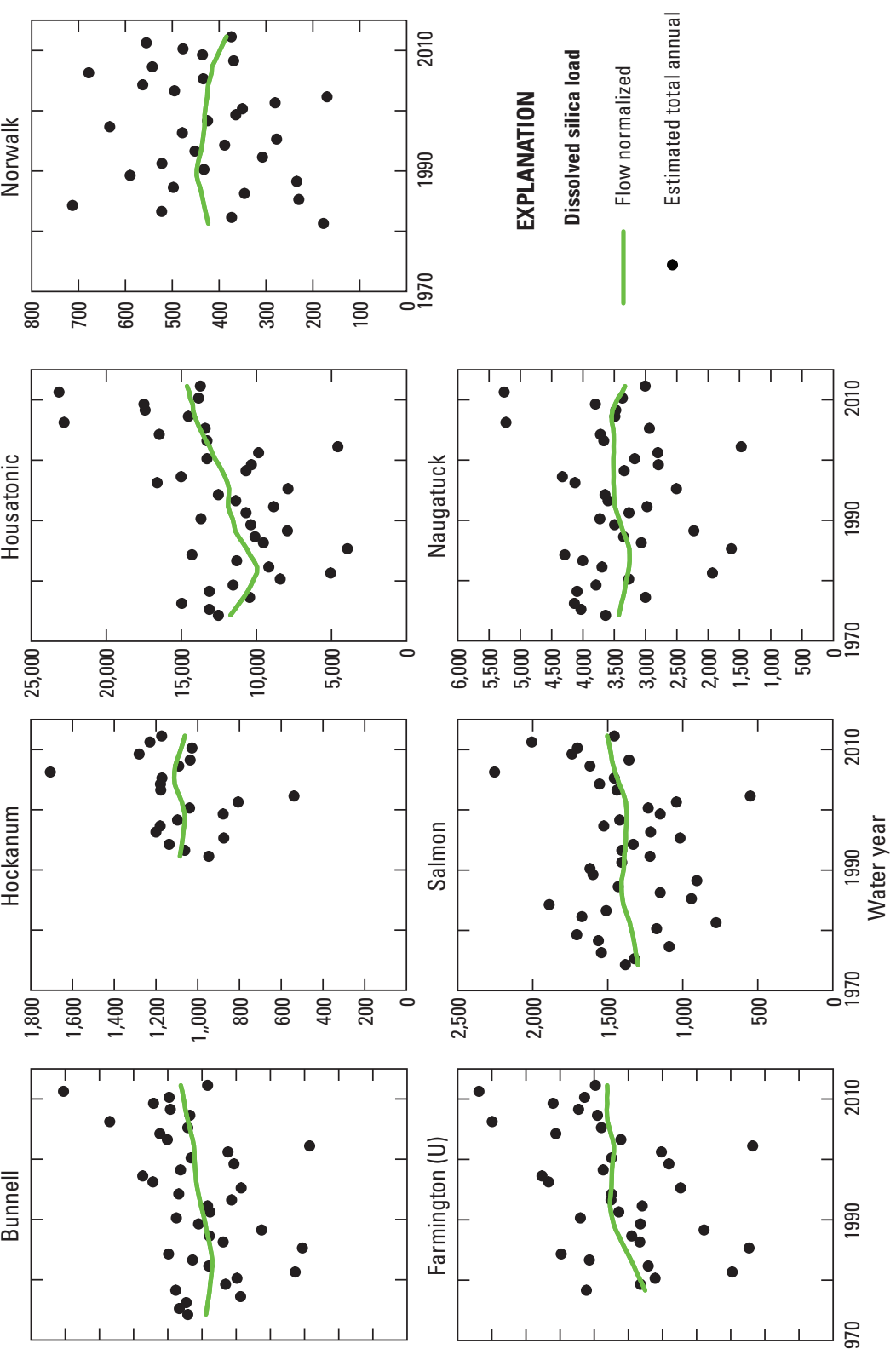

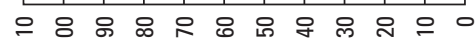

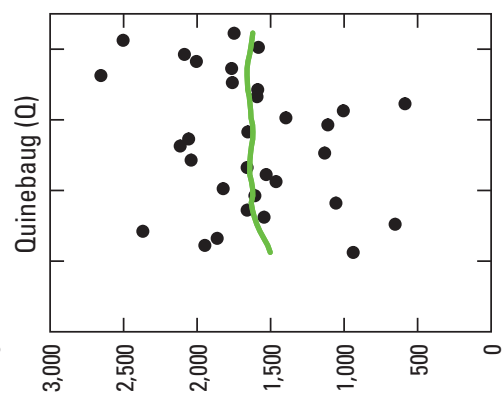

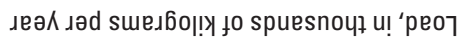
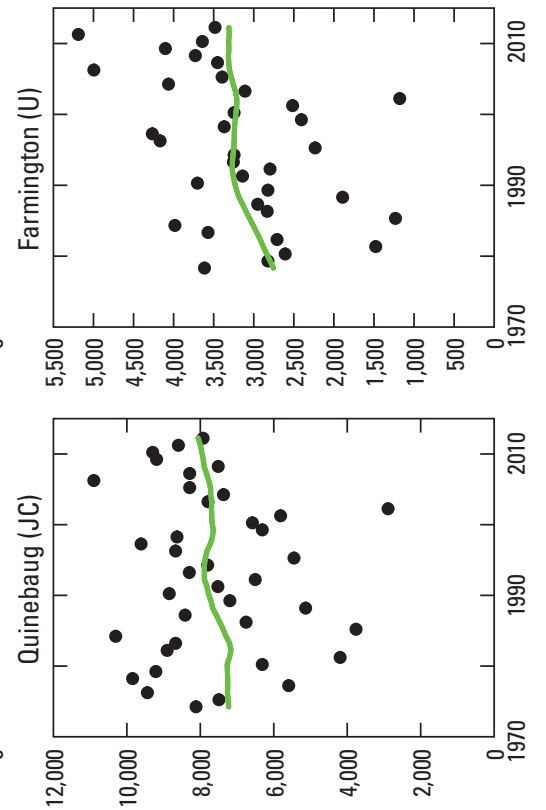

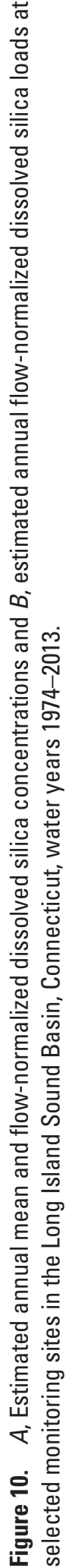


Table 8. Change in flow-normalized concentrations and flow-normalized loads of dissolved silica at selected monitoring sites in the Long Island Sound Basin, Connecticut, water years 1974-2013 and water years 2001-13.

[mg/L, milligrams per liter]

\begin{tabular}{|c|c|c|c|c|c|c|}
\hline Station & $\begin{array}{l}\text { Beginning } \\
\text { water year }\end{array}$ & $\begin{array}{c}\text { Ending } \\
\text { water year }\end{array}$ & $\begin{array}{l}\text { Change in load } \\
\text { (metric tons/year) }\end{array}$ & $\begin{array}{l}\text { Change in load } \\
\text { (percent) }\end{array}$ & $\begin{array}{l}\text { Change in } \\
\text { concentration } \\
\text { (mg/L) }\end{array}$ & $\begin{array}{c}\text { Change in } \\
\text { concentration } \\
\text { (percent) }\end{array}$ \\
\hline Shetucket & 1974 & 2013 & 590 & 11 & 0.36 & 4.8 \\
\hline Quinebaug(Q) & 1981 & 2013 & 110 & 7.3 & 0.4 & 7.7 \\
\hline Quinebaug(JC) & 1974 & 2013 & 868 & 12 & -0.11 & -2 \\
\hline Connecticut & 1974 & 2013 & 8,202 & 9.4 & 0.58 & 11 \\
\hline Bunnell & 1974 & 2013 & 7.7 & 13 & 0.6 & 6.7 \\
\hline Farmington(U) & 1978 & 2013 & 560 & 20 & 0.71 & 17 \\
\hline Farmington(T) & 1974 & 2013 & 509 & 8.3 & 0.21 & 3.5 \\
\hline Hockanum & 1992 & 2013 & -33 & -3 & -0.9 & -9.1 \\
\hline Salmon & 1974 & 2013 & 209 & 16 & 0.77 & 9.7 \\
\hline Quinnipiac & 1974 & 2013 & 30 & 1.5 & -0.62 & -6 \\
\hline Housatonic & 1974 & 2013 & 2,973 & 25 & 0.87 & 22 \\
\hline Naugatuck & 1974 & 2013 & -152 & -4.4 & -1.3 & -18 \\
\hline Saugatuck & 1974 & 2013 & 38 & 14 & 1.1 & 14 \\
\hline Norwalk & 1982 & 2013 & -49 & -11 & -0.52 & -7.6 \\
\hline Shetucket & 2001 & 2013 & 510 & 9.5 & 0.57 & 7.8 \\
\hline Quinebaug(Q) & 2001 & 2013 & -23 & -1.4 & -0.054 & -0.97 \\
\hline Quinebaug(JC) & 2001 & 2013 & 406 & 5.3 & 0.098 & 1.8 \\
\hline Connecticut & 2001 & 2013 & 4,424 & 4.9 & 0.35 & 6.6 \\
\hline Bunnell & 2001 & 2013 & 4.3 & 6.8 & 0.67 & 7.6 \\
\hline Farmington(U) & 2001 & 2013 & 102 & 3.2 & 0.091 & 1.9 \\
\hline Farmington(T) & 2001 & 2013 & 117 & 1.8 & 0.18 & 3 \\
\hline Hockanum & 2001 & 2013 & -23 & -2.1 & -0.37 & -4 \\
\hline Salmon & 2001 & 2013 & 129 & 9.3 & 0.44 & 5.3 \\
\hline Quinnipiac & 2001 & 2013 & -34 & -1.7 & -0.63 & -6 \\
\hline Housatonic & 2001 & 2013 & 1,746 & 13 & 0.78 & 19 \\
\hline Naugatuck & 2001 & 2013 & -233 & -6.7 & -0.64 & -9.9 \\
\hline Saugatuck & 2001 & 2013 & 22 & 7.5 & 0.72 & 9 \\
\hline Norwalk & 2001 & 2013 & -50 & -12 & -0.67 & -9.6 \\
\hline
\end{tabular}

The slight increases in flow-normalized and non-flownormalized loads of DSi, relative to generally declining loads of TN and TP, indicate the potential for improvement to the food web of LIS, which may have become Si limited in the last 30-40 years (1973-83; Varekamp and others, 2004). A system limited by Si can cause shifts from diatoms to dinoflagellates as primary producers. The presence of dinoflagellates increases the likelihood of harmful algal blooms, which have occurred in some parts of LIS. Some research has indicated a seasonal Si limitation in some parts of LIS (Gobler and others 2006). The ratio of DSi relative to TN is expected to improve with further reductions in nitrogen loading throughout the entire basin. This improvement will likely favor a shift in the food web of LIS to one more dominated by diatoms.

\section{Chloride}

Flow-normalized concentrations and loads of $\mathrm{Cl}$ increased substantially at all sites for both time periods, except for the Naugatuck (decrease in flow-adjusted concentration) and Connecticut river sites, during water years 2001-13 (table 10). The Naugatuck River subbasin has undergone many 
Table 9. Multiple linear-regression model variables used to describe variability in silica yields and the relation to selected landcover/land-use characteristics. The adjusted $\mathrm{R}^{2}$ was 0.66 .

[Std., standard]

\begin{tabular}{lcccc}
\hline \multicolumn{1}{c}{ Variable } & Coefficient & Std. error & $\boldsymbol{t}$-value & $\boldsymbol{p}$-value \\
\hline Intercept & 58.5549 & 5.8195 & 10.0619 & $<0.00001$ \\
Area of water in the basin, in percent & -6.667 & 1.9422 & -3.4327 & 0.0056 \\
Area of developed land in the basin, in percent & 0.3392 & 0.1387 & 2.4448 & 0.0325 \\
\hline
\end{tabular}

changes that could explain the lack of a trend in this river. Changes include WWTP and stormwater treatment upgrades, decrease of metal working and rubber industries, and the elimination of direct discharges from these industrial facilities (Connecticut Department of Environmental Protection, 2001).

The increase in flow-normalized $\mathrm{Cl}$ loads and concentrations averaged 112 and 103 percent, respectively, for the entire study period and 29.2 and 28.7 percent for water years 2001-13, respectively. Sites with the largest changes in flownormalized load during the entire study period include Bunnell (164 percent), Hockanum (161 percent, 1992-2013) and the Shetucket (134 percent). Increases in flow-normalized concentrations were 12,48 , and $12 \mathrm{mg} / \mathrm{L}$, respectively, from water years 1974 to 2013 (fig. 12, table 10).

Increases in $\mathrm{Cl}$ in rivers in the northern United States have been documented previously by Mullaney and others (2009), Corsi and others (2015), and Kaushal and others (2005). The increases in $\mathrm{Cl}$ concentrations and loads can be attributed to the following sources: deicing salts applied to public roads and private property, and discharges from WWTFs and on-site septic systems. Less important sources include atmospheric deposition, the use of salts for water softening, and potassium chloride in agricultural fertilizers (Mullaney and others, 2009). The largest source of the increase is likely to be the use of salt for deicing. Deicing salt use in the

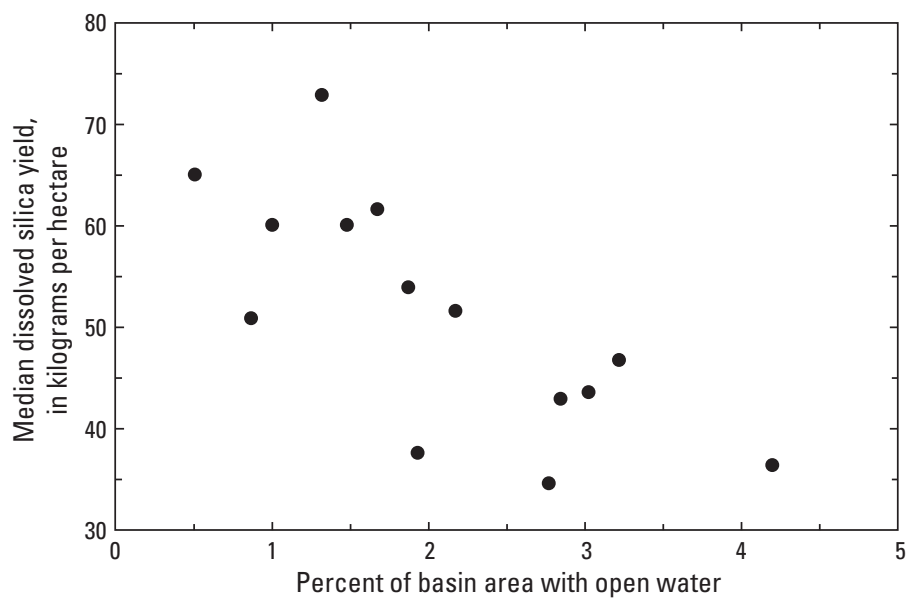

United States has increased from about 8 million metric tons in 1975 to nearly 20 million metric tons in 2011 (U.S. Geological Survey, 2004-13, 2013).

At the basins studied in this investigation, no concentrations of $\mathrm{Cl}$ exceeded recommended acute $(860 \mathrm{mg} / \mathrm{L})$ or chronic $(230 \mathrm{mg} / \mathrm{L})$ criteria intended to protect aquatic life (U.S. Environmental Protection Agency, 1988). If current trends continue, it can be expected that these recommended criteria will be exceeded in the future at some of the sites studied. With the periodic (typically monthly) sampling that is done for this network, it is likely that episodic high $\mathrm{Cl}$ concentrations resulting from deicing salt in runoff or meltwater are not frequently measured because often these high $\mathrm{Cl}$ events last only a few hours (Brown and others, 2015). The change in flow-normalized concentrations of $\mathrm{Cl}$ were generally largest at most sites during the winter months (fig. 13), indicating a relation with winter deicing. Concentrations also increased to a lesser degree during the summer months, indicating either higher $\mathrm{Cl}$ in base flow or increasing volume of wastewater discharge over time. Concentrations at the Naugatuck River have decreased at low flows and increased slightly for all other flows, a possible indication of decreasing effects from wastewater or groundwater sources (fig. 13).

Figure 11. Relation between percent of open water area in each monitored basin and dissolved silica yields at selected monitoring sites in the Long Island Sound Basin, Connecticut, water years 2001-13. 

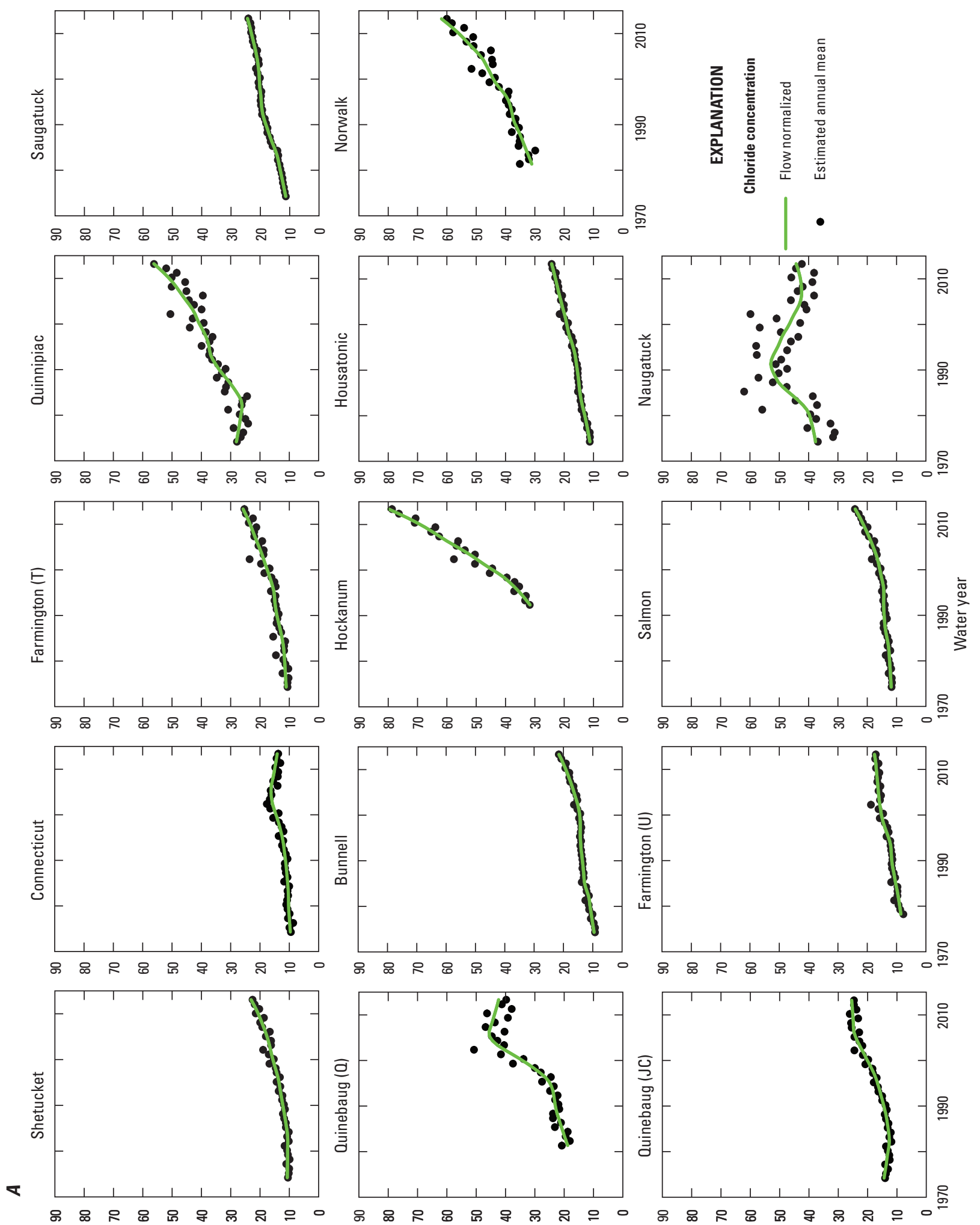

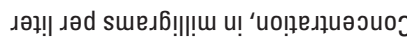

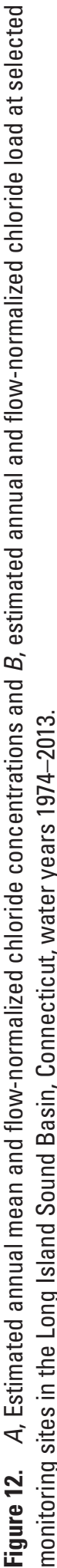



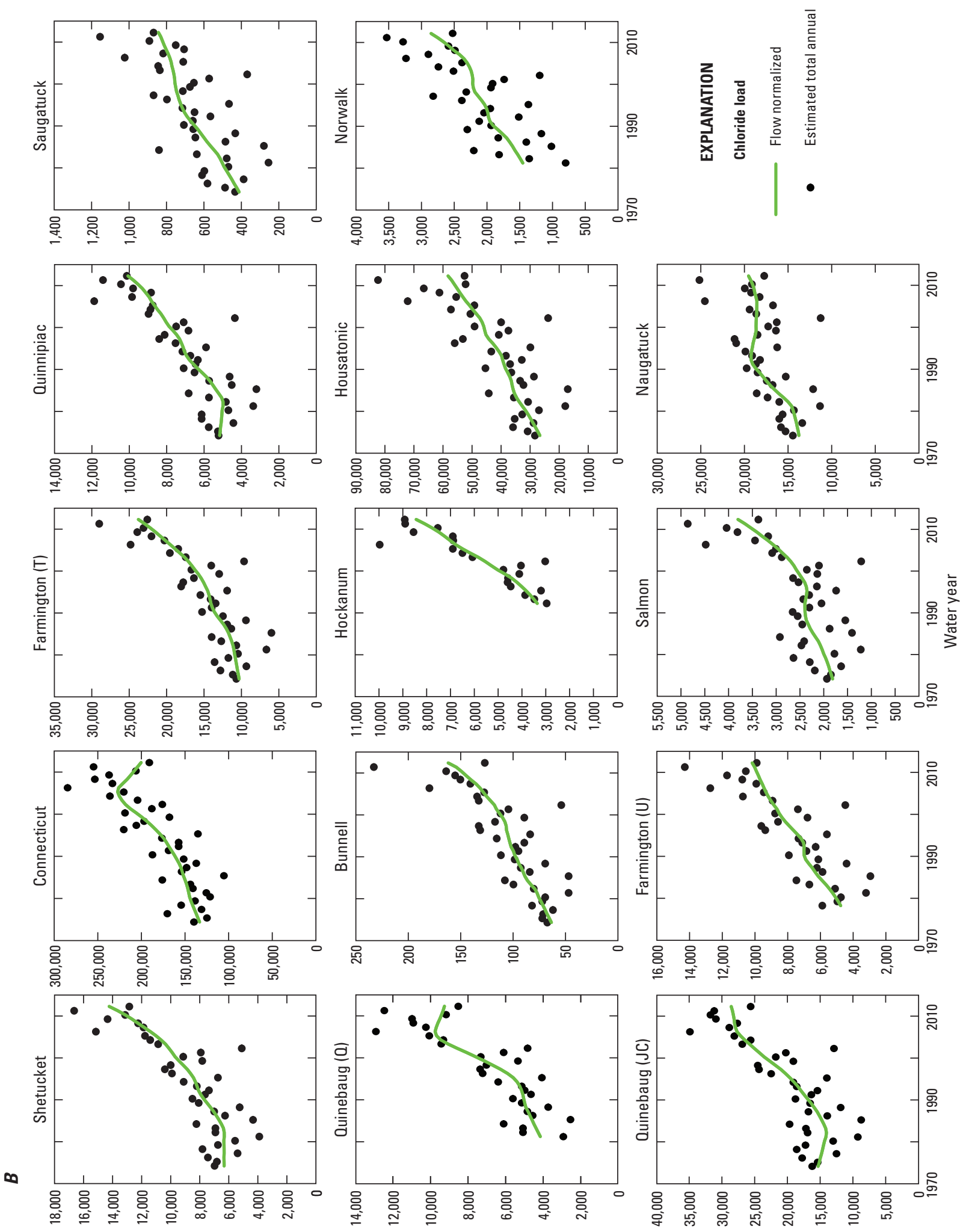

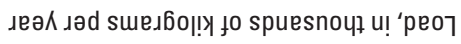

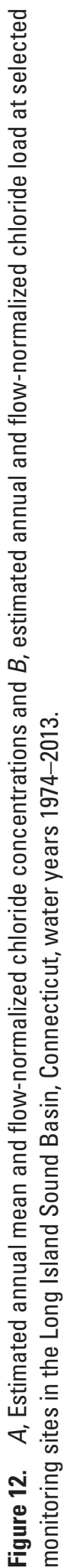


Table 10. Change in flow-normalized concentrations and flow-normalized loads of chloride at selected monitoring sites in the Long Island Sound Basin, Connecticut, water years 1974-2013 and water years 2001-13.

[mg/L, milligrams per liter]

\begin{tabular}{|c|c|c|c|c|c|c|}
\hline Station & $\begin{array}{l}\text { Beginning } \\
\text { water year }\end{array}$ & $\begin{array}{c}\text { Ending } \\
\text { water year }\end{array}$ & $\begin{array}{l}\text { Change in load } \\
\text { (metric tons/year) }\end{array}$ & $\begin{array}{c}\text { Change in load } \\
\text { (percent) }\end{array}$ & $\begin{array}{c}\text { Change in } \\
\text { concentration } \\
\text { (mg/L) }\end{array}$ & $\begin{array}{c}\text { Change in } \\
\text { concentration } \\
\text { (percent) }\end{array}$ \\
\hline Shetucket & 1974 & 2013 & 8,461 & 134 & 12 & 115 \\
\hline Quinebaug(Q) & 1981 & 2013 & 5,017 & 121 & 24 & 125 \\
\hline Quinebaug(JC) & 1974 & 2013 & 13,396 & 87 & 11 & 77 \\
\hline Connecticut & 1974 & 2013 & 63,067 & 47 & 4.5 & 46 \\
\hline Bunnell & 1974 & 2013 & 104 & 164 & 12 & 125 \\
\hline Farmington(U) & 1978 & 2013 & 5,562 & 117 & 9 & 105 \\
\hline Farmington(T) & 1974 & 2013 & 14,311 & 139 & 15 & 133 \\
\hline Hockanum & 1992 & 2013 & 5,430 & 161 & 48 & 153 \\
\hline Salmon & 1974 & 2013 & 2,124 & 117 & 12 & 104 \\
\hline Quinnipiac & 1974 & 2013 & 5,187 & 100 & 28 & 100 \\
\hline Housatonic & 1974 & 2013 & 32,565 & 122 & 13 & 118 \\
\hline Naugatuck & 1974 & 2013 & 6,010 & 44 & 6.6 & 18 \\
\hline Saugatuck & 1974 & 2013 & 442 & 107 & 13 & 116 \\
\hline Norwalk & 1981 & 2013 & 1,491 & 103 & 31 & 100 \\
\hline Shetucket & 2001 & 2013 & 4,888 & 49 & 7 & 44 \\
\hline Quinebaug(Q) & 2001 & 2013 & 1,092 & 14 & 4.7 & 13 \\
\hline Quinebaug(JC) & 2001 & 2013 & 4,435 & 18 & 4.4 & 21 \\
\hline Connecticut & 2001 & 2013 & $-16,130$ & -7.6 & -1.1 & -7.5 \\
\hline Bunnell & 2001 & 2013 & 51 & 44 & 6.8 & 45 \\
\hline Farmington(U) & 2001 & 2013 & 1,667 & 19 & 2.1 & 14 \\
\hline Farmington(T) & 2001 & 2013 & 7,972 & 48 & 7.5 & 41 \\
\hline Hockanum & 2001 & 2013 & 3,497 & 66 & 32 & 68 \\
\hline Salmon & 2001 & 2013 & 1,310 & 50 & 8 & 50 \\
\hline Quinnipiac & 2001 & 2013 & 2,322 & 29 & 15 & 35 \\
\hline Housatonic & 2001 & 2013 & 12,681 & 27 & 4.7 & 25 \\
\hline Naugatuck & 2001 & 2013 & 1,106 & 5.9 & -1.4 & -3.1 \\
\hline Saugatuck & 2001 & 2013 & 97 & 13 & 3.9 & 19 \\
\hline Norwalk & 2001 & 2013 & 729 & 33 & 17 & 37 \\
\hline
\end{tabular}


Connecticut River, Water Years 1974-2013

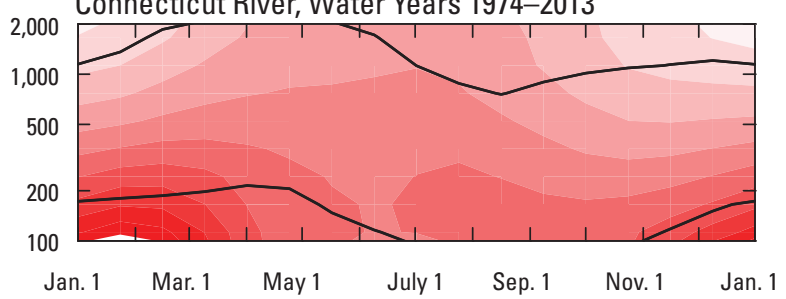

Farmington (T) River, Water Years 1974-2013

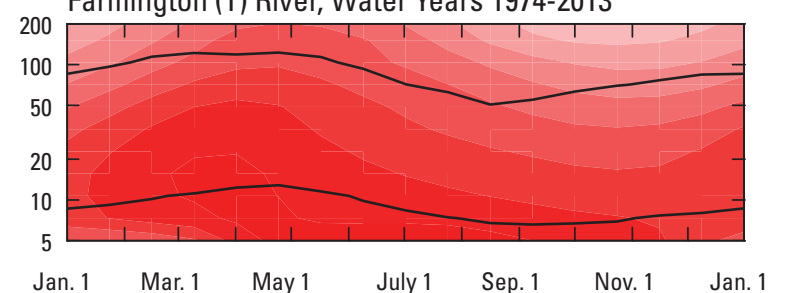

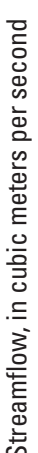

\section{Chloride}

Concentration change,

in milligrams per liter

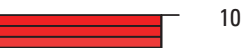

5

0

$-5$

$-10$

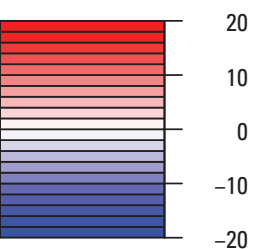

$-20$

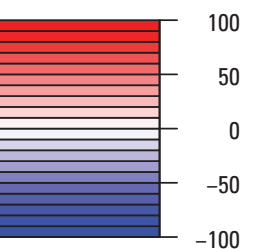

$-100$

Salmon River, Water Years 1974-2013

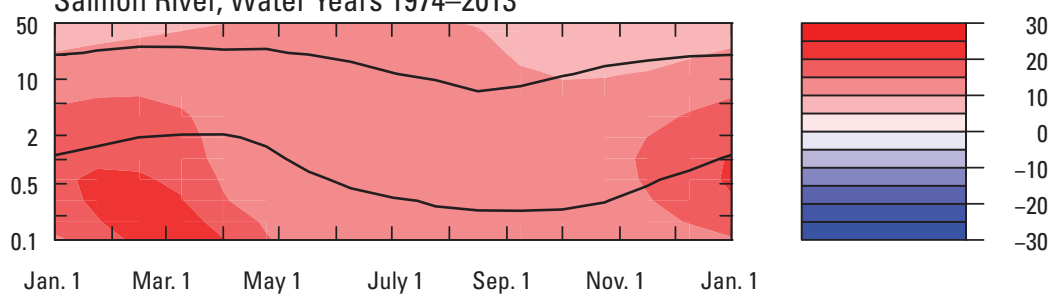

Naugatuck River, Water Years 1974-2013
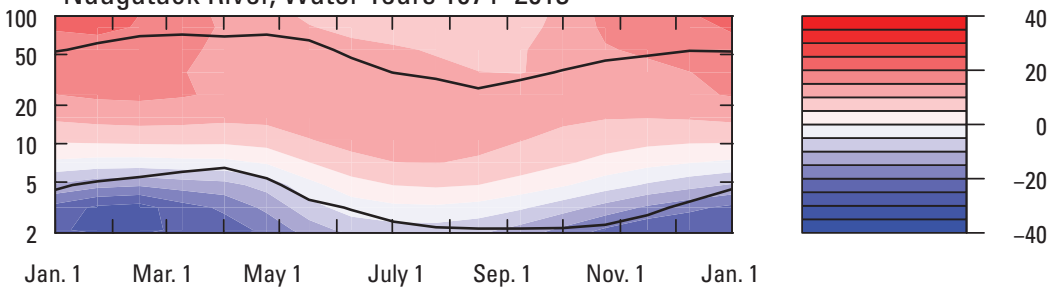

EXPLANATION

5th and 95th flow percentiles

Figure 13. Change in expected flow-adjusted chloride concentrations and streamflow at selected sites in the Long Island Sound Basin, Connecticut, water years 1974-2013. 


\section{Summary and Conclusions}

The long-term record of streamflow, nutrients, total organic carbon (TOC) and chloride $(\mathrm{Cl})$ in Connecticut streams that flow to Long Island Sound (LIS) was documented in a study conducted by the U.S. Geological Survey, in cooperation with the Connecticut Department of Energy and Environmental Protection, using a recently developed methodology that allows for flexibility in the relations among streamflow, season, and time. The method calculates a trend in concentrations or loads by removing the effects of variation in streamflow. In addition to the trend analysis, the focus of the research was to understand the effects of land-use changes and management programs in the subbasins on water quality, beginning near the time of implementation of the Federal Clean Water Act of 1972. Evaluations were conducted for water years 1974-2013, following the Federal Clean Water Act, and for 2001-13, following the beginning of the Nitrogen Credit Exchange program (NCE) in Connecticut.

Results from this study of constituent concentrations and loads at 14 selected monitoring sites in Connecticut indicate that the flow-normalized total nitrogen (TN) loads from the major tributaries in Connecticut to LIS have decreased since the 1970s and since the beginning of the NCE program in 2001. Decreases in flow-adjusted loads averaged 23.9 percent for 1974-2013 and 10.9 percent for 2001-13. Decreases appear to be related to management actions that have reduced nitrogen loads in discharge from wastewater treatment facilities and to the decrease in wet deposition of nitrate $\left(\mathrm{NO}_{3}^{-}\right)$. In basins without wastewater treatment facilities, flow-normalized TN concentrations and loads have increased slightly during 2001-13, possibly owing to loss of forest cover and increased development. Decreases are prominent for flownormalized concentrations and loads of TN in basins with wastewater treatment facilities; however, trends in non-flownormalized loads from these rivers are masked by high streamflows in some years and increasing streamflow in general, particularly during the summer.

Streamflow increased in both periods, averaging 8 percent for water years 1974-2013 and 9 percent for water years 2001-13. Increases were consistent and, in general, greatest during the summer and fall seasons for both periods. Annual maximum streamflows increased an average of 21.6 percent during the 2001-13 period, including the Connecticut River site, which decreased. Further study is needed to understand the increases in streamflow and to include projections for streamflow that can be used to further management actions that can reduce nitrogen loading.

Nearly all 14 sites studied had decreases in flow-normalized concentrations and loads of total phosphorus (TP) and total organic carbon (TOC). Changes in flow-normalized loads of TP were attributed to bans on phosphate detergents, improvements in wastewater treatment, and possibly other less dominant factors, including the loss or changes in management of agricultural land. Decreases in flow-normalized concentrations and loads of TOC are also likely the result of improvements in wastewater treatment; however, the cause for decreases in TOC in basins with no wastewater discharges is less certain.

Loads of dissolved silica (DSi; flow-normalized and non-flow-normalized) increased slightly at most stations during the study period. Possible causes of the increases include declining TP loads and concentrations, and changes in land use. Median yields of DSi during water years 2001-13 were positively related to developed land use and negatively related to the area of water in each basin. With the general decreases in TN and TP, the ratios among these nutrients and DSi may be returning to a more favorable condition for LIS, which will favor blooms of diatoms over dinoflagellates, especially if additional wastewater treatment improvements continue to be made in Connecticut and other parts of the LIS Basin.

Concentrations of Chloride $(\mathrm{Cl}$; flow-normalized and non-flow-normalized) increased at all 14 sites during water years 1974-2013 and at 12 of the 14 sites during water years 2001-13. Changes over the entire study period were greater than in the more recent years. The increase in flownormalized $\mathrm{Cl}$ loads and concentrations averaged 112 and 103 percent, respectively, for the entire study period and 29.2 and 28.7 percent for the water years $2001-13$, respectively. If current trends continue, it can be expected that recommended aquatic criteria will be exceeded in the future at some of the sites studied. The largest source of these increases in chloride concentrations and loads is likely to be the use of salt for deicing.

\section{Selected References}

Bernal, S., Hedin, L.O., Likens, G.E., Gerber, S., and Buso, D.C., 2012, Complex response of the forest nitrogen cycle to climate change: Proceedings of the National Academy of Sciences, v. 109, no. 9, p. 3406-3411.

Brown, C.J., Mullaney, J.R., Morrison, Jonathan, Martin, J.R., and Trombley, T.J., 2015, Chloride concentrations, loads, and yields in four watersheds along Interstate 95, southeastern Connecticut, 2008-11-Factors that affect peak chloride concentrations during winter storms: U.S. Geological Survey Scientific Investigations Report 2015-5057, 68 p., http://dx.doi.org/10.3133/sir20155057.

Butler, T.J., Vermeylen, F.M., Rury, M., Likens, G.E., Lee, B., Bowker, G.E., and McCluney, L.M., 2010, Response of ozone and nitrate to stationary source $\mathrm{NO}_{\mathrm{x}}$ emission reductions in the eastern USA: Atmospheric Environment, v. 45, p. 1084-1094.

Carey, J.C., and Fulweiler, R.W., 2011, Human activities directly alter watershed dissolved silica fluxes: Biogeochemistry, v. 111, no. 1, p. 125-138. 
Clesceri, L.S., Greenburg, A.E., and Eaton, A.D., eds., 1998, Standard methods for the examination of water and wastewater (20th ed.): Washington D.C., American Public Health [variously paged].

Cleveland, W.S., 1979, Robust locally weighted regression and smoothing scatterplots: Journal of the American Statistical Association, v. 74, p. 829-836.

Cleveland, W.S., and Devlin, S.J., 1988, Locally weighted regression: An approach to regression analysis by local fitting: Journal of the American Statistical Association, v. 83, p. 596-610.

Cohn, T.A., Caulder, D.L., Gilroy, E.J., Zynjuk, L.D., and Summers, R.M., 1992, The validity of a simple statistical model for estimating fluvial constituent loads: An empirical study involving nutrient loads entering Chesapeake Bay: Water Resources Research, v. 28, no. 9, p. 2353-2363.

Commonwealth of Massachusetts, Department of Environmental Protection, 2013, Enhanced implementation plan: Preliminary evaluation of current stormwater and nonpoint source control efforts in Massachusetts, 63 p., accessed May 19, 2015, at http://www.neiwpcc.org/neiwpcc_docs/ LIS\%20TMDL_MA\%20State\%20Section.pdf.

Connecticut Department of Energy and Environmental Protection, 2013a, 2013 Long Island Sound Hypoxia Season Review, accessed December 11, 2014, at http://longislandsoundstudy.net/wp-content/ uploads/2013/06/2013-Season-Review.pdf.

Connecticut Department of Energy and Environmental Protection, 2013b, Report of the Nitrogen Credit Advisory Board for calendar year 2012, to the Joint Standing Environment Committee of the General Assembly: Hartford, Conn., Connecticut Department of Energy and Environmental Protection, 42 p., accessed October 26, 2015, at http://www.ct.gov/deep/lib/deep/water/ municipal_wastewater/nitrogen_report_2012.pdf.

Connecticut Department of Energy and Environmental Protection, 2013c, Evaluation of stormwater and nonpoint source control efforts in the Long Island Sound Watershed, 77 p., accessed May 19, 2015, at http://www.neiwpcc.org/ neiwpcc_docs/LIS\%20TMDL_CT\%20State\%20Section. pdf.

Connecticut Department of Energy and Environmental Protection, 2014a, 2014 State of Connecticut integrated water quality report: Final-October, 2014, 350 p., accessed May 7, 2015, at http://www.ct.gov/deep/lib/deep/water/ water_quality_management/305b/2014_iwqr_305b_303d_ final.pdf.
Connecticut Department of Energy and Environmental Protection, 2014b, Connecticut's Nitrogen Trading Program, presentation, accessed December 11, 2014, at http://www.ct.gov/deep/lib/deep/water/ municipal_wastewater/9_17_14_pres_futureplans_ntp.pdf.

Connecticut Department of Energy and Environmental Protection, undated, accessed March 30, 2015, at http://www.ct.gov/deep/cwp/view. $\operatorname{asp} ? \mathrm{a}=2688 \& \mathrm{Q}=456150 \&$ depNav_GID $=1511$.

Connecticut Department of Environmental Protection, 2001, Environmental compliance in Connecticut: prepared for the Connecticut General Assembly Committee on the Environment, accessed June 12, 2015, at http://www.ct.gov/deep/ lib/deep/enforcement/reports/2000annualreport.pdf.

Corsi, S.R., De Cicco, L.A., Lutz, M.A., and Hirsch, R.M., 2015, River chloride trends in snow-affected urban watersheds: increasing concentrations outpace urban growth rate and are common among all seasons: Science of the Total Environment, v. 508, p. 488-497.

Deacon, J.R., Smith, T.E., Johnston, C.M., Moore, R.B., Weidman, R.M., and Blake, L.J., 2006, Assessment of total nitrogen in the Upper Connecticut River Basin in New Hampshire, Vermont, and Massachusetts, December 2002September 2005: U.S. Geological Survey Scientific Investigations Report 2006-5144, 89 p.

Ficke, J.F., and Hawkinson, R.O., 1975, The national stream quality accounting network (NASQAN) — some questions and answers: U.S. Geological Survey Circular 719, 23 p.

Fishman, M.J., ed., 1993, Methods of analysis by the U.S. Geological Survey National Water Quality Laboratory-Determination of inorganic and organic constituents in water and fluvial sediments: U.S. Geological Survey Open-File Report 93-125, 217 p.

Fishman, M.J., and Friedman, L.C., 1989, Methods for determination of inorganic substances in water and fluvial sediments: U.S. Geological Survey Techniques of WaterResources Investigations, book 5, chap. A1, 545 p.

Flynn, R.H., 2014, Analysis of floods, including the tropical storm Irene inundation, of the Ottauquechee River in Woodstock, Bridgewater, and Killington and of Reservoir Brook in Bridgewater and Plymouth, Vermont: U.S. Geological Survey Scientific Investigations Report 2014-5214, 13 p., http://dx.doi.org/10.3133/sir20145214.

Gilliom, R.J., Alley, W.M., and Gurtz, M.E., 1995, Design of the National Water-Quality Assessment ProgramOccurrence and distribution of water-quality conditions: U.S. Geological Survey Circular 1112, 33 p. 
Gobler, J.G., Buck, N.J., Sieracki, M.E., and SanudoWilhelmy, S.A., 2006, Nitrogen and silicon limitation of phytoplankton communities across an urban estuary: The East River-Long Island Sound system: Estuarine, Coastal and Shelf Science, v. 68, no. 1-2, p. 127-138.

Gronberg, J.M., Ludtke, A.S., and Knifong, D.L., 2014, Estimates of inorganic nitrogen wet deposition from precipitation for the conterminous United States, 1955-84: U.S. Geological Survey Scientific Investigations Report 2014-5067, 18 p., http://dx.doi.org/10.3133/sir20145067.

Hartmann, J., Levy, J., and Kempe, S., 2011, Increasing dissolved silica trends in the Rhine River: An effect of recovery from high P loads?: Limnology, v. 12, p. 63-73.

Helsel, D.R., and Hirsch, R.M., 2002, Statistical Methods in Water Resources Techniques of Water Resources Investigations, book 4, chap. A3: U.S. Geological Survey, 522 p.

Hirsch, R.M., and De Cicco, Laura, 2014, User guide to Exploration and Graphics for RivEr Trends (EGRET) and dataRetrieval: R packages for hydrologic data: U.S. Geological Survey Techniques and Methods, book 4, chap. A10, 94 p., http://dx.doi.org/10.3133/tm4A10.

Hirsch, R.M., Moyer, D.L., and Archfield, S.A., 2010, Weighted Regressions on Time, Discharge, and Season (WRTDS), with an application to Chesapeake Bay River inputs: Journal of the American Water Resources Association, v. 46, no. 5, p. 857-880.

Hodgkins, G.A., and Dudley, R.W., 2011, Historical summer base flow and stormflow trends for New England rivers: Water Resources Research, v. 47, 16 p.

Jin, S., Yang, L., Danielson, P., Homer, C., Fry, J., and Xian, G., 2013, A comprehensive change detection method for updating the National Land Cover Database to circa 2011: Remote Sensing of Environment, v. 132, p. 159-175.

Kaushal, S.J., Groffman, P.M., Likens, G.E., Belt, K.T., Stack, W.P., Kelly, V.R., Band, L.E., and Fisher, D.T., 2005, Increased salinization of fresh water in the northeastern United States: Proceedings of the National Academy of Sciences, v. 102, no. 38, p. 13517-13520.

Long Island Sound Study, 2010, Status and trends, environmental indicators: watershed population, accessed May 7 , 2015, at http://longislandsoundstudy.net/2010/08/ watershed-population/.

Loucaides, S., Cahoon, L.B., and Henry, E.J., 2007, Effects of watershed impervious cover on dissolved silica loading in storm flow: Journal of the American Water Resources Association, v. 43, no. 4, p. 841-849.
Litke, D.W., 1999, Review of phosphorus control measures in the United States and their effects on water quality: U.S. Geological Survey Water-Resources Investigations Report 99-4007, 38 p.

Medalie, L., Hirsch, R.M., and Archfield, S.A., 2012, Use of flow-normalization to evaluate nutrient concentration and flux changes in Lake Champlain tributaries, 1990-2009: Journal of Great Lakes Research, 38, Supplement 1, p. $58-67$.

Mullaney, J.R., Schwarz, G.E., and Trench, E.C.T., 2002, Estimation of nitrogen yields and loads from basins draining to Long Island Sound, 1988-98: U.S. Geological Survey Water-Resources Investigations Report 02-4044, 84 p.

Mullaney, J.R., Lorenz, D.L., and Arntson, A.D., 2009, Chloride in groundwater and surface water in areas underlain by the glacial aquifer system, northern United States: U.S. Geological Survey Scientific Investigations Report 2009-5086, 41 p., http://pubs.usgs.gov/sir/2009/5086/.

Mullaney, J.R., and Schwarz, G.E., 2013, Estimated nitrogen loads from selected tributaries in Connecticut draining to Long Island Sound, 1999-2009: U.S. Geological Survey Scientific Investigations Report 2013-5171, 65 p., http://pubs.usgs.gov/sir/2013/5171/.

Murphy, J.C., Hirsch, R.M., and Sprague, L.A., 2013, Nitrate in the Mississippi River and its Tributaries, 1980-2010An update: U.S. Geological Survey Scientific Investigations Report 2013-5169, 31 p., http://pubs.usgs.gov/ $\operatorname{sir} / 2013 / 5169 /$

National Atmospheric Deposition Program, 2013, NADP Program Office, Illinois State Water Survey: Champaign, Ill., National Atmospheric Deposition Program, accessed August 25, 2015, at http://nadp.sws.uiuc.edu/data/annualmaps.aspx.

New England Interstate Water Pollution Control Commission, 2014, A preliminary and qualitative evaluation of the adequacy of current stormwater and nonpoint source nitrogen control efforts in achieving the 2000 Long Island Sound total maximum daily load for dissolved oxygen, 70 p., accessed August 24, 2015, at http://www.neiwpcc.org/neiwpcc_docs/ LIS\%20TMDL_Watershed\%20Synthesis\%20Section.pdf.

New Hampshire Department of Environmental Services, 2013, State report for New Hampshire: Qualitative assessment of stormwater and nonpoint source control efforts in the Long Island Sound (LIS) watershed, 59 p., accessed May 19, 2015, at http://www.neiwpcc.org/neiwpcc_docs/ LIS\%20TMDL_NH\%20State\%20Section.pdf. 
New York State Department of Environmental Conservation and Connecticut Department of Environmental Protection, 2000, A total maximum daily load analysis to achieve water-quality standards for dissolved oxygen in Long Island Sound: Albany, N.Y., New York State Department of Environmental Conservation and Hartford, Conn., Connecticut Department of Environmental Protection, 73 p.

Patton, C.J., and Kryskalla, J.R., 2011, Colorimetric determination of nitrate plus nitrite in water by enzymatic reduction, automated discrete analyzer methods: U.S. Geological Survey Techniques and Methods, book 5, chap. B8, 34 p., at http://pubs.usgs.gov/tm/05b08/.

Patton, C.J., and Truitt, E.P., 2000, Methods of analysis by the U.S. Geological Survey National Water Quality Laboratory-Determination of ammonium plus organic nitrogen by a Kjeldahl digestion method and an automated photometric finish that includes digest cleanup by gas diffusion: U.S. Geological Survey Open-File Report 00-170, 31 p., http://pubs.usgs.gov/of/2000/0170/report.pdf.

Patton, C.J., and Truitt, E.P., 1992, Methods of analysis by the U.S. Geological Survey National Water Quality Laboratory; determination of the total phosphorus by a Kjeldahl digestion method and an automated colorimetric finish that includes dialysis: U.S. Geological Survey Open-File Report 92-146, 39 p. [Also available at http://pubs.er.usgs.gov/ publication/ofr92146.]

Pinder, R.W., Appel, K.W., and Dennis, R.L., 2011, Trends in atmospheric reactive nitrogen for the eastern United States: Environmental Pollution, v. 159, no. 10, p. 3138-3141.

Rice, K.C., and Hirsch, R.M., 2012, Spatial and temporal trends in runoff at long-term streamgages within and near the Chesapeake Bay Watershed: U.S. Geological Survey Scientific Investigations Report 2012-5151, 56 p. [Also available at http://pubs.usgs.gov/sir/2012/5151/.]

Runkel, R., Crawford, C., and Cohn, T.A., 2004, Load Estimator (LOADEST): A FORTRAN Program for estimating constituent loads in streams and rivers: U.S. Geological Survey Techniques and Methods, book 4, chap. A5, 69 p., http://pubs.usgs.gov/tm/2005/tm4A5/.

Sprague, L.A., Hirsch, R.M., and Aulenbach, B.T., 2011, Nitrate in the Mississippi River and its tributaries, 1980 to 2008: Are we making progress?: Environmental Science and Technology, v. 45, no. 17, p. 7209-7216.

Sprague, L.A., Mueller, D.K., Schwarz, G.E., and Lorenz, D.L., 2009, Nutrient trends in streams and rivers of the United States, 1993-2003: U.S. Geological Survey Scientific Investigations Report 2008-5202, 196 p., http://pubs.usgs.gov/sir/2008/5202/pdf/SIR08-5202.pdf.
Stanley, E.H., Powers, S.M., Lottig, N.R., Buffam, I., and Crawford, J.T., 2012, Contemporary changes in dissolved organic carbon (DOC) in human-dominated rivers: is there a role for DOC management?: Freshwater Biology, no. 57 (suppl. 1), p. 26-42.

Trench, E.C.T., 1996, Trends in surface-water quality in Connecticut, 1969-88: U.S. Geological Survey Water-Resources Investigations Report 96-4161, 176 p.

Trench, E.C.T., 2000, Nutrient sources and loads in the Connecticut, Housatonic, and Thames River Basins: U.S. Geological Survey Water-Resources Investigations Report 99-4236, 66 p.

Trench, E.C.T., Moore, R.B., Ahearn, E.A., Mullaney, J.R., Hickman, R.E., and Schwarz, G.E., 2012, Nutrient concentrations and loads in the northeastern United States - Status and trends, 1975-2003: U.S. Geological Survey Scientific Investigations Report 2011-5114, 169 p. [Also available at http://pubs.usgs.gov/sir/2011/5114.]

Trench, E.C.T., and Vecchia, A.V., 2002, Water-quality trend analysis and sampling design for streams in Connecticut, 1968-98: U.S. Geological Survey Water-Resources Investigations Report 02-4011, 94 p., http://pubs.usgs.gov/ wri/2002/4011/report.pdf.

University of Connecticut Center for Land Use Education and Research, undated a, Long Island Sound Watershed's Changing Landscape: Haddam, Conn., University of Connecticut Center for Land Use Education and Research, accessed June 18, 2015, at http://clear.uconn.edu/projects/ landscapeLIS/index.htm.

University of Connecticut Center for Land Use Education and Research, undated b, Long Island Sound Watershed's Changing Landscape: Haddam, Conn., University of Connecticut Center for Land Use Education and Research, accessed June 18, 2015, at http://clear.uconn.edu/projects/ landscapeLIS/pdfs/IS_Coefficient_Generation_Procedure. pdf.

U.S. Environmental Protection Agency, 1988, Ambient water quality criteria for chloride-1988: U.S. Environmental Protection Agency Office of Water Regulations and Standards 440/5-88-001, 47 p.

U.S. Environmental Protection Agency, 1993, Determination of phosphorus by semi-automated colorimetry (revision 2.0), method 365.1 of Methods for the determination of inorganic substances in environmental samples: U.S. Environmental Protection Agency EPA/600/R-93/100, p. $365.1-1-365.1-17$. 
U.S. Environmental Protection Agency, 2013, Clean air interstate rule, acid rain program, and former $\mathrm{NO}_{\mathrm{x}}$ budget trading program, 2012 progress $\mathrm{SO}_{2}$ and $\mathrm{NO}_{x}$ emissions, compliance, and market analyses: Washington, D.C., U.S. Environmental Protection Agency, 14 p., accessed January 20, 2015, at http://www.epa.gov/airmarkets/progress/

ARPCAIR_12_downloads/ARPCAIR12_01.pdf.

U.S. Geological Survey, 2004-13, Salt: U.S. Geological Survey Minerals Yearbook 2002-2011 [variously paged], accessed June 15, 2015, at http://minerals.usgs.gov/ minerals/pubs/commodity/salt/.

U.S. Geological Survey, 2013, Salt end-use statistics [through 2003; last modified September 1, 2005], in Kelly, T.D., and Matos, G.R., comps., Historical statistics for mineral and material commodities in the United States (2013 version): U.S. Geological Survey Data Series 140, 3 p., accessed March 28, 2013, at http://minerals.usgs.gov/minerals/pubs/ historical-statistics/.

U.S. Geological Survey, [undated], Table of computed runoff by water-year for Connecticut: U.S. Geological Survey Water Watch Web site, accessed June 23, 2015, at http://waterwatch.usgs.gov/index.php?r=ct\&id=statesum.

Varekamp, J.C., McElroy, A.E., Mullaney, J.R., and Breslin, V.T., 2014, Metals, organic compounds, and nutrients in Long Island Sound: sources, magnitudes, trends, and impacts, in Latimer, J.S., Tedesco, M.A., Swanson, R.L., Yarish, C., Stacey, P., Garza, C., eds., 2014, Long Island Sound: Prospects for the Urban Sea: New York, Springer, p. 203-283.
Varekamp, J.C., Thomas, E., and Beuning, K., 2004, Environmental change in Long Island Sound over the last 400 years, final report: U.S. Environmental Protection Agency Assistance Agreement X-9812950-1, 28 p., accessed October 26, 2015, at http://longislandsoundstudy.net/wp-content/ uploads/2010/02/varekampfinal.pdf.

Wershaw, R.L., Fishman, M.J., Grabbe, R.R., and Lowe, L.E., 1987, Methods for the determination of organic substances in water and fluvial sediments: U.S. Geological Survey Techniques of Water-Resources Investigations, book 5, chap. A3, 80 p.

Zimmerman, M.J., Grady, S.J., Trench, E.C.T., Flanagan, S.M., and Nielsen, M.G., 1996, Water-quality assessment of the Connecticut, Housatonic, and Thames River Basins study unit-Analysis of available data on nutrients, suspended sediments, and pesticides, 1972-92: U.S. Geological Survey Water-Resources Investigations Report 95-4203, 162 p.[Also available at http://pubs.er.usgs.gov/publication/ wri954203.] 



\section{Appendixes}

\section{Appendix 1. Summary of Water-Quality Laboratory Method References for Samples Collected at Selected Streams in the Long Island Sound Basin, Water Years 1974-2013}

Appendix 1-1. Summary of water-quality laboratory method references for samples collected at selected streams in the Long Island Sound Basin, water years 1974-2013. 
Appendix 1-1. Summary of water-quality laboratory method references for samples collected at selected streams in the Long Island Sound Basin, water years 1974-2013.

[<1986, method began prior to year stated]

\begin{tabular}{|c|c|c|c|c|}
\hline Constituent & $\begin{array}{l}\text { Parameter } \\
\text { code }\end{array}$ & $\begin{array}{c}\text { Dates } \\
\text { (water years) }\end{array}$ & Method reference & Remarks \\
\hline Total Kjeldahl nitrogen & 00625 & $<1986-1991$ & Fishman and Friedman, 1989 & \\
\hline Nitrite plus nitrate nitrogen & 00630,00631 & $<1986-1988$ & Fishman and Friedman, 1989 & \\
\hline Nitrite plus nitrate nitrogen & 00630,00631 & $<1988-2011$ & Patton and Kryskalla, 2011 & \\
\hline Total phosphorus & 00665 & 1991-2013 & Patton and Truitt, 1992 & $\begin{array}{l}\text { Sites with high total phosphorus: Hockanum, } \\
\text { Quinnipiac, Naugatuck }\end{array}$ \\
\hline Total phosphorus & 00665 & 1999-2013 & $\begin{array}{l}\text { U.S. Environmental Protection } \\
\text { Agency, } 1993\end{array}$ & \\
\hline Total organic carbon & 00680 & $<1985-2009$ & Wershaw and others, 1987 & \\
\hline Silica & 00955 & 1990-1994 & Fishman and Friedman, 1989 & \\
\hline Silica & 00955 & 1994-2013 & Fishman, 1993 & \\
\hline Chloride & 00940 & $<1986-1990$ & Fishman and Friedman, 1989 & \\
\hline Chloride & 00940 & 1990-1992 & Fishman, 1993 & \\
\hline Chloride & 00940 & $1992-1993$ & Fishman and Friedman, 1989 & \\
\hline Chloride & 00940 & 1994-2013 & Fishman, 1993 & \\
\hline
\end{tabular}




\section{Appendix 2. Weighted Regressions on Time, Discharge, and Season Method Outputs}

[Available separately for download at http://dx.doi.org/10.3133/sir20155189]

Table 2-1. Streamflow, concentrations and loads of total nitrogen, flow-normalized concentrations and loads and bias statistics for total nitrogen at selected monitoring sites in the Long Island Sound Basin, Connecticut, water years 1974-2013.

Table 2-2. Streamflow, concentrations and loads of total Kjeldahl nitrogen, flow-normalized concentrations and loads and bias statistics for total Kjeldahl nitrogen at selected monitoring sites in the Long Island Sound Basin, Connecticut, water years 1974-2013.

Table 2-3. Streamflow, concentrations and loads of nitrate plus nitrite nitrogen, flow-normalized concentrations and loads and bias statistics for nitrate plus nitrite nitrogen at selected monitoring sites in the Long Island Sound Basin, Connecticut, water years 1974-2013.

Table 2-4. Streamflow, concentrations and loads of total phosphorus, flow-normalized concentrations and loads and bias statistics for total phosphorus at selected monitoring sites in the Long Island Sound Basin, Connecticut, water years 1974-2013.

Table 2-5. Streamflow, concentrations and loads of total organic carbon, flow-normalized concentrations and loads and bias statistics for total organic carbon at selected monitoring sites in the Long Island Sound Basin, Connecticut, water years 1974-2013.

Table 2-6. Streamflow, concentrations and loads of dissolved silica, flow-normalized concentrations and loads and bias statistics for dissolved silica at 14 selected monitoring sites in the Long Island Sound Basin, Connecticut, water years 1974-2013.

Table 2-7. Streamflow, concentrations and loads of chloride, flow-normalized concentrations and loads and bias statistics for chloride at 14 selected monitoring sites in the Long Island Sound Basin, Connecticut, water years 1974-2013. 

For more information concerning this report, contact: Director, New England Water Science Center U.S. Geological Survey 1101 Pitkin Street East Hartford, CT 06108 dc_nweng@usgs.gov or visit our Web site at: http://newengland.water.usgs.gov

Publishing support by:

The Pembroke Publishing Service Center. 
